DEPARTMENT OF THF, INTERIOR

UNITED STATES GEOLOGICAL SURVEY

CHARLES D WALCOTT, Director.

\title{
Contributions to the Geology of Washington
}

Geology and Physiography of Central Washington

BY GEORGE OTIS SMITH

Physiography and Deformation of the Wenatchee-Chelan District Cascade Range

By BAIIEY WILLIS

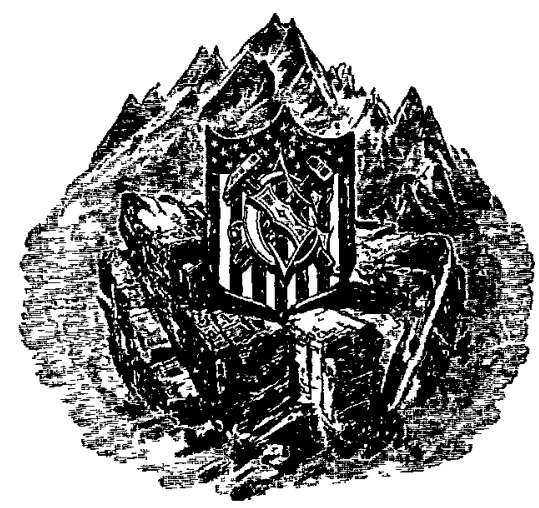

WASIIING TON

GOVRRNMHNT PRINTING OFHICE

1903 

CONTRIBUTIONS TO THE GEOLOGY OF WASHINGTON

\section{GEOLOGY AND PHYSIOGRAPHY OF GENTRAL WASHINGTON}

Bบ

GEORGE OTIS SMITH 



\section{CONTENTS.}

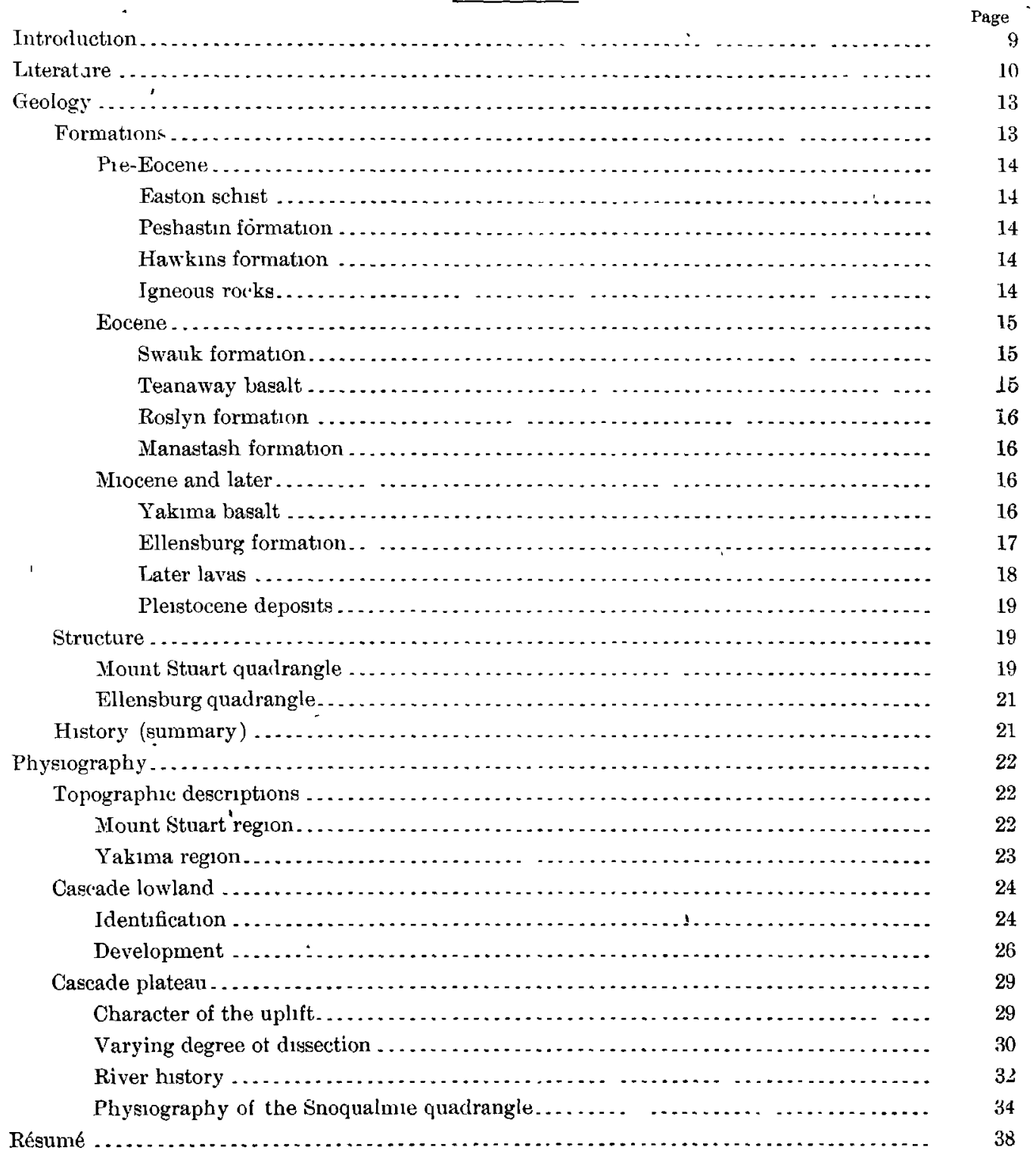





\section{ILLUSTRATIONS.}

Paga

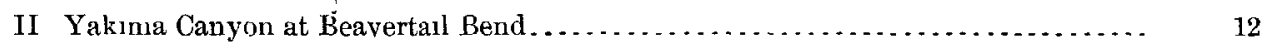

III Geologic map of a portion of the Mount Stuart quadrangle. . . . . . . . . . . . . . . 14

IV Geologic map of a portion of the Ellensburg quadrangle $\ldots \ldots \ldots \ldots \ldots \ldots \ldots \ldots \ldots \ldots$

V. Physiographic sketch map of a portion of the Ellensbuig quadrangle ........... 26

VI. Map of Yakma Canyon, with geologic section ....................... 32

VII. Map of Snoqualmie quadrangle . . . . . . . . . . . . . . . . . . . . . . . . . 36

FIG 1 Contact of Ellensburg sandstone and Yakuma basalt $\ldots \ldots \ldots \ldots \ldots \ldots \ldots \ldots \ldots \ldots \ldots$ 



\title{
GEOLOGY AND PHYSIOGRAPIIY OF CENTRAL WASHINGTON.
}

\author{
By George Otis Smith.
}

\section{INTRODUCTION.}

Central Washington includes a part of two great topographic provinces, the great plain of the Columbia and the Cascade Range. The former, in its position and general desert-like character, suggests at once a resemblance to the Great Basin of Utah and Nevada; and the vastness of the desert plain is emphasized by the snowy peaks of the Cascades along its western border. These provinces are not to be regarded as unconnected in their geologic history, however great the contrast in their general features. The intermediate zone between the great plain on the east and the mountain range on the west is a strategic point for the investigation of the geologic structure and history and the interpretation of the present topography of hoth provinces. On the extensive basalt-covered plain monotony wearies the traveler, while on the rocky peaks of the Cascades the complexity taxes the powers of the observer.

Yakima River, an important tributary of the Columbia, drains a large area on the eastern slope of the Cascade Mountains, and in the medial portion of its course this river traverses a region which shares many of the features belonging to the two provinces mentioned above. The Mount Stuart and Ellensburg quadrangles ${ }^{a}$ are situated close to the geographic center of the State of Washington and include an area of about 1,600 square miles In the southern portion of this area the country is characterized by broad valleys and low, gently sloping ridges. The general absence of forest trees and the abundance of the sagebrush are other features that remind the traveler of the great plain to the east. In the northern part of the Mount Stuart quadrangle the ridges are of a bolder type and the extremely rugged topography of Mount Stuart and other portions of the Wenatchee Mountains suggests at once the main range of the Cascades. These two quadrangles have been surveyed both topographically and geologically, and the results of these surveys constitute the basis of the present paper.

$a$ Under the plan adopted by this survey for the preparation of a geologic map of the United States the entire a rea is divided into small quadrangles, bounded by certain meridians and parallels, and each 19 named from some well-known place or feature appearing in it 
In the preparation of this paper I have had the privilege of frequent conference with Mr. Bailey Willis. His familiarity with the area here described has given special value to his helpful criticism, which is gratefully acknowledged. Portions of the area described by Mr. Willis have also been visited by myself, and I believe the conclusions reached in his paper to be in general agreement with the results of the work in central Washington. The separation of the two areas and the fact that the field work was more or less distinct and conducted under different conditions led to the publication of our results as two papers, rather than as a joint contribution to the geology of the region. In the mapping of the Ellensburg quadrangle I was assisted by Mr. Frank C. Calkins.

The results of this survey have been published in the Ellensburg folio, No. 86, of the Geologic Atlas of the United States.

\section{ITTERATURE.}

A glance at the literature which is available regarding this area will serve to show the present state of our knowledge of the geology and physiography of central Washington. Russell ${ }^{a}$ records the occurrence of older crystalline rocks in this area, separated by an unconformity from overlying sediments of early Tertiary age. Above these, with another unconformity, is the great series of lava flows, named by Russell the "Columbia lava," $b$ above which is another sedimentary series of Miocene age, correlated by Russell with the John Day beds of Oregon. Professor Russell's determination of the age of the Cascade Range as post-Miocene ${ }^{c}$ is provisional only, but the antecedent character of the main streams of the region is more definitely stated, as follows:

"The evidence that the main drainage lines of central Washington were established before the present relief was initiated is cumulative and abundant. The rivers began to flow when Lake John Day was drained and bad their courses determined by the slope of the surface of the bottom of the old lake. Since then mountain ranges have been formed by faulting, but the larger streams, i. e., the Columbia and Yakima, were able to cut down their channels as rapidly as the ridges were upraised athwart their channels." $d$

The structure of the range is thus described:

"It seems probable that the Cascades are formed to a large extent of tilted blocks of basalt which were originally horizontal, and belong to the same series as the Columbia [River] lavas farther east, which have been, in comparison, only moderately disturbed. The Cascade Mountains, at least in the State of Washington, do not seem to have been formed mainly by the piling up of erupted material, as has been suggested in explanation of their origin farther south, but are due to the

a A geological reconnaissance in central Washington: Bull. U. S. Geol. Survey No, 108, pp. 20-25. bThis has later been termed by Russell the Columbia River lava.

a Ibid., p. 24 . $\quad d$ Ibid., p. 97. 


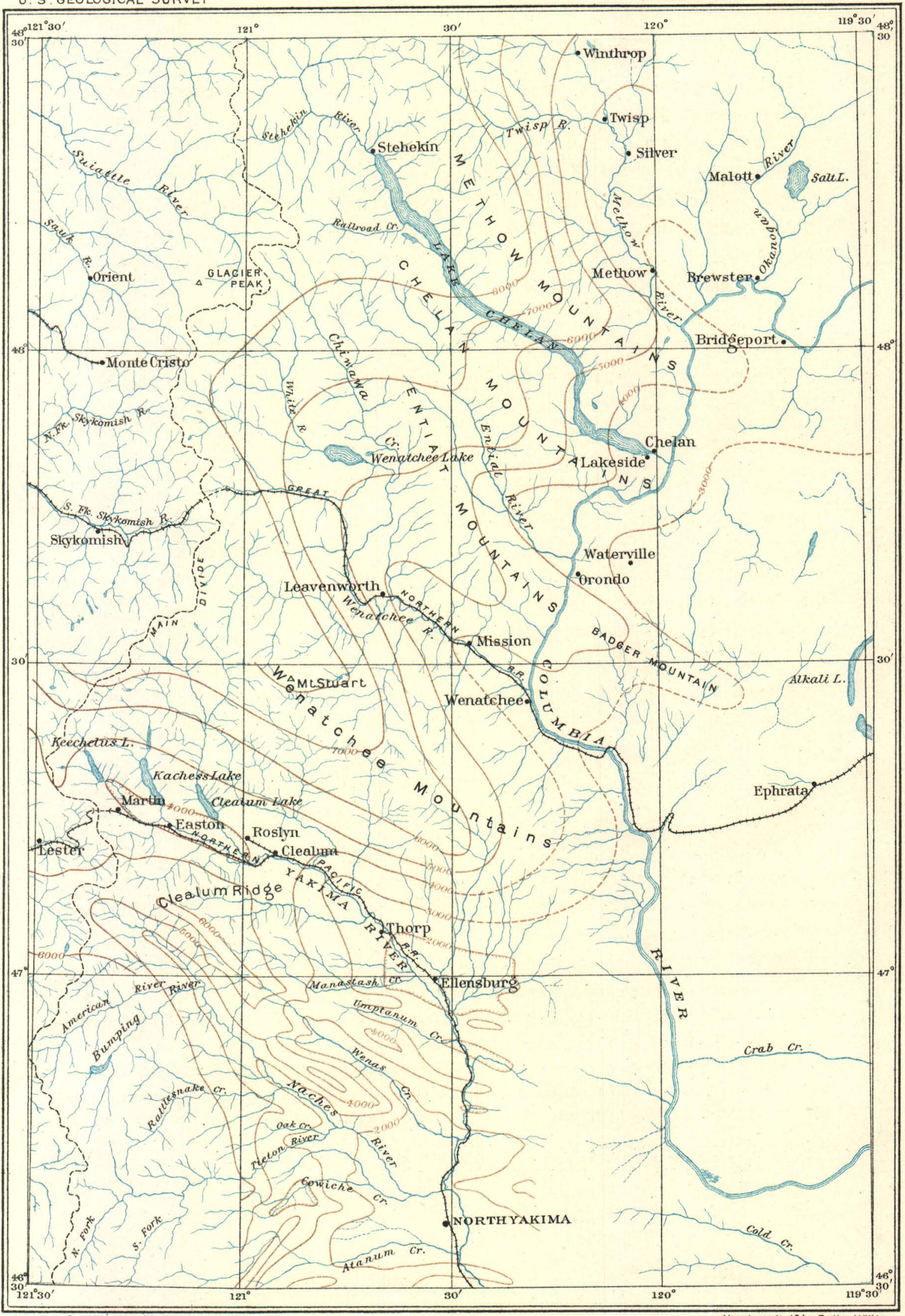

Drainage from topographic maps

MAP OF CENTRAL WASHINGTON

Northern half by Bailey Will is
Southernhalf by George OtisSmith

CONTOURS ON RESTORED WARPED SURFACE OF THE METHOW (PLIOCENE) PENEPLAIN

$$
\frac{\text { Scale }}{10 \quad 5} \quad \frac{0}{1003} \text { 30 miles }
$$


uplifting and tilting of previously consolidated lava sheets, as well as of granite and coal-bearing strata, which occur high up on each flank of the mountain, and even form portions of the main divide. The great volcanoes which appear so prominent along the general trend of the range are secondary to the main mountain building." $a$

In a later publication ${ }^{b}$ Professor Russell describes more fully the Columbia River lava, and states that its maximum thickness in the Snake River region is over 5,000 feet. ${ }^{c}$ The geologic history of the whole of the Columbia Plains area is sketched. $^{d}$ In early Tertiary times there were mountains in what is now northern Washington and eastern Idaho, but the central and southern portions of the Cascades were not yet in existence. In the area now including the great plain of the Columbia sedimentation went on in early Tertiary times, clays and sands being deposited, with accumulations of regetable matter later changed to coal. Upheaval of these sediments "brought these once level sheets of rock above the sea and raised them into a mountain range, the southern Cascade." Erosion followed this upheaval, and later came the eruptions of the basaltic lavas which were spread over thousands of square miles. Succeeding the volcanic outbursts came lacustral sedimentation in broad lakes, probably formed "by the upheaval of the Cascade Mountains." These Miocene sediments are those which Professor Russell earlier called the John Day. Since the draining of the Miocene lakes Snake River has performed an immense task, baving carved in the basalt platean a gorge about 15 miles broad at the top and in places about 4,000 feet deep.

A later paper gives a fuller development of Professor Russell's ${ }^{e}$ interpretation of the geologic history of the Cascade Range. The geologic formations are more fully described, mention being made of the older metamorphic schists, the igneous rocks, granite, greenstone, and serpentine, the sedimentary rocks of pre-Cretaceous, Cretaceous, and Tertiary age, and the Columbia River lava and volcanic rocks of Glacier Peak. On the subject of the structure of the northern Cascades Professor Russell says: "It will be seen that the structure of the range is highly complex, and is by no means a single great, north-south anticline, or a simple monoclinal block sculptured by erosion." $f$ Attention is also called to lateral folds and faults on the eastern side of the range in central Washington, and the age of these secondary disturbances is shown to be late Tertiary or post-Tertiary, and apparently contemporaneous " with the latest great upward movement in the Cascade Mountain mass." Again the author notes the antecedent character of the Columbia and Yakima, which cross in narrow gaps these "tilted blocks." The origin of the range

a A geological reconnaissance in central Waghington. Bull U S. Geol. Survey No. 108, p 30

b A reconnaissance in southern Washington Water-Sup and Irr. Paper No. 4, U, S Geol Survey. $o$ Ibud , p. 42.

$\epsilon$ A preliminary paper on the geology of the Cascade Mountains in northern Washington Twentieth Ann. Rept U. S. Geol survey, pt 2 .

I Ibíd. p 187 . 
is thus stated: "The Cascade Mountains, as we know them, seem to have been carved from an upraised peneplain. This plain we term the Cascade peneplain; and the plateau may be conveniently designated the Cascade plateau." a Russell's hypothesis of a Cascade peneplain rests upon the presence of truncated folds, stream erosion having reduced the whole region nearly to sea level. "During the later portion of the time of base-leveling, the widely spread sheets of Columbia [River] lava were poured out. The date of the period of planation is shown approximately by the fact that folded beds of Eocene age were truncated. The broad peneplain must therefore have reached its greatest degree of perfection in late Tertiary time, probably extending into the Pleistocene." ${ }^{b}$ It will be noted that the epoch of great basalt eruptions is thus included in the period of reduction to base-level.

In brief, Professor Russell's "conception of the origin of the larger topographic features of the northern Cascades is that the region, having a complex structure, was reduced by erosion to a condition of low relief, and at a later date than the folding of the Tertiary sediments and the outspreading of the Columbia [River] lava was broadly upraised about 7,500 feet in the axial region. The courses of the larger streams were then established and the plateau was deeply dissected." $c$ The author then describes the extent to which the dissection of the Cascade plateau has proceeded, and mentions in this connection the striking feature that the larger streams of central Washington, of which Yakima River is the best example, have carried the low grade far back toward the axis of the range. ${ }^{d}$ It is also noted that the courses of the streams are in a marked way independent of the structure of the upraised region. ${ }^{e}$

In attempting to determine the position of the upraised peneplain surface, Professor Russell observes that no recognizable flat-topped remnants of the original platean are to be found in the more elevated portions of the range, but that the sharp-crested ridges and acute peaks may testify to a general diminution in height in the case of the soft rocks, while the harder rocks, such as the granites, more nearly approximate the original elevation of the plateau. Such evidence that the surface of the Cascade plateau has been somewhat lowered by erosion is not thought by Professor Russell to be conclusive. ${ }^{f}$

In a later paper, ${ }^{g}$ Professior Russell goes into a discussion of the character of the plateau which was built up by the Columbia River lava. Taking as a premise the gencral parallelism of the succession of the lava flows as exposed in canyon walls, he argues that during the period of eruption there were no general movements such as would cause unconformities within the Columbia River series. This lava is

a A preliminary paper on the geology of the Cascade Mountains in northern Washington: Twentieth Aun. Rept., U. S. Geol. Survey, pt. 2, p. 140

o Ibld, p. 144. $\quad$ c Ibid., p. 142. $\quad$ d Ibid., p. 145. $\quad$ e Ibid., p. $150 . \quad f$ Ibid., p. 141.

$g$ The geology and water resources of Nez Perces County, Idaho: Water-Sup. and Irr. Paper No. 54, U. S. Geol. Survey. 


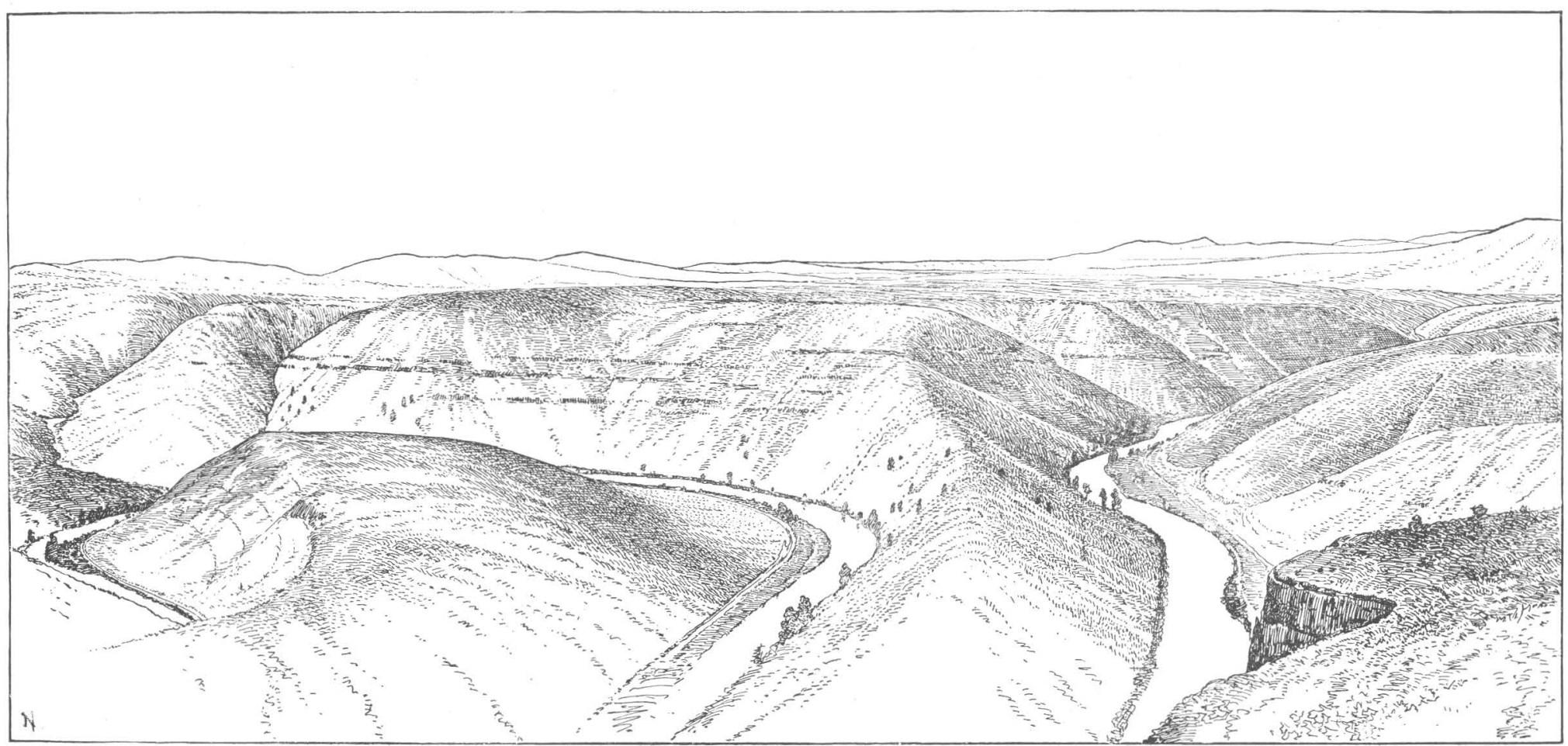

YAKIMA CANYON AT BEAVERTAIL BEND. 
believed to have been poured out in a "series of vast inundations over a deeply eroded land surface." Since the series is in places over 4,000 feet thick, if there was no subsidence during the period of eruption the surface of the last flow must have had at least that elevation above the sea. That there were no movements producing a depression during the period of eruption is believed by Professor Russell on the grounds that there are no marine sediments interbedded with the lava sheets; and neither have unconformities been detected in the eastern portion of the area covered by the Columbia River lava. On this account the horizontal surface of the lava plateaus in eastern Washington and Oregon and the adjacent part of Idaho should have an elevation of at least 4,000 feet or more above the sea. On the contrary, the elevation of such plateaus is between 3,000 and 3,300 feet, and this difference of approximately 1,000 feet is supposed by Russell to indicate a general subsidence of the eastern portion of the lava region. In his discussion of the drainage of this area Professor Russell, however, still regards Snake River where it crosses the lava plateau as an antecedent stream.

\section{GEOLOGY.}

FORMATIONS.

The two quadrangles which this paper chiefly describes contain rocks of various ages. The geologic section is fairly representative for the whole State, and its discussion is therefore of more than local interest. Pls. III and IV show the geology of characteristic portions of the two quadrangles. The separation of the older and the younger rocks is an obvious one, and would he noted by any close observer. In a general way it may be stated that within this area the oldest rocks lie to the north, in the vicinity of Mount Stuart, and the youngest to the south. To describe this section as a southward-dipping monocline, however, would be misleading, since this would disregard the many marked unconformities which separate the different formations.

In this chapter the rocks will be grouped according to age as pre-Eocene, Eocene, and Miocene and later. The first class includes rocks that are unfossiliferous and plainly more or less altered, with intrusive rocks predominating. Above the base of the Eocene the rocks are fresher in appearance and contain fossils by which their exact age is determined, while the igneous rocks are chiefly surface volcanics. The Miocene rocks are so fresh appearing that in places it is difficult to distinguish them from recent deposits. Thus it will be seen that the grouping adopted is a natural one.

These formations are more fully described in the Fllensburg folio, No. 86, and the Mount Stuart folio, which is in the course of publication. 
PRE-EOCENE.

Easton schist.-This is probably the oldest rock to be found in central Washington. It is not shown upon either of the accompanying geologic maps, but occupies a few square miles in the southwestern part of the Mount Stuart quadrangle and extends westward into the Snoqualmie quadrangle. Here it forms in large part the southern wall of the Yakima Valley, and is especially prominent southeast of the town of Easton.

The Easton schist is typically a silver-gray or green rock, composed principally of quartz and micas. The schist is extremely crumpled and is gashed and seamed with veins and stringers of quartz. Associated with this quartz-mica rock are other schists, containing hornblende or epidote, while quartzite is also found. The occurrence of this quartzite in close association with the schists is believed to indicate the sedimentary origin of the schists.

Peshastin formation. - South of the Mount Stuart massif occurs a series of sedimentary rocks that may rank next to the Easton schist in age. These are black slate, with grit or conglomerate, and bands of black chert and lenses of light-gray limestone interbedded with the slate. In places these rocks show metamorphism by the igneous rocks with which they are in contact, and nowhere in the many exposures of this formation have any traces of fossils been discovered.

It seems plausible to assign this sedimentary formation to the Paleozoic, and it is possible that it is of Carboniferous age. This age determination rests simply upon a general resemblance of the formation to the Carboniferous rccks of the Sierra Nevada and of British Columbia. Rocks also strikingly similar to the Peshastin formation are found in the Blue Mountains of Oregon and in the Okanogan Valley in northern Washington.

Hawkins formation.-This is a volcanic series of flow-breccias, tuffs, and amygdaloids. These rocks are dark colored, green, or purple, extremely altered, and everywhere exerting a marked influence upon the topography, rough slopes with ragged crests being characteristic of this formation. While composed largely of secondary minerals, these lavas and tuffs preserve their original texturcs, and microscopic study shows that the rocks were originally composed of augite and plagioclase, with diabasic texture. The whole series undoubtedly represents surface lava flows with associated tuffs. The Hawkins and Peshastin formations have been intricately mingled by close folding, while subsequent intrusions of igneous rock have also obscured relations.

Igneous rocks.-Surrounding the older rocks just described are great belts of serpentine. This rock is intrusive, and its extent within the Mount Stuart quadrangle is important, since it covers nearly 50 square miles. The serpentine is an altered phase of peridotite, the latter rock being found in its original state at many 
U. S. GEOLOGICAL SURVEY

PROFESSIONAL PAPER NO.I9 PL. III

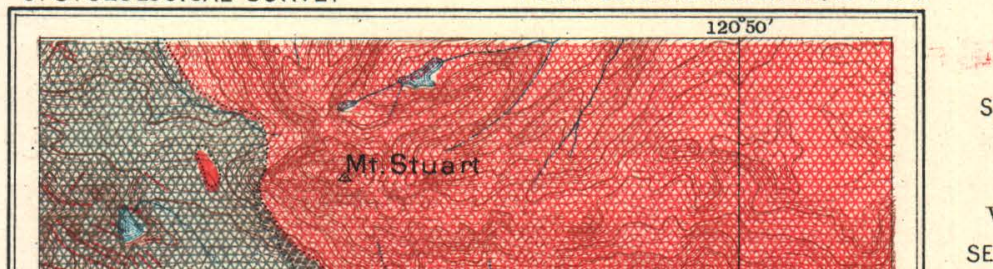

\section{LEGEND}

SURFICIALROCKS

PLEISTOCENE

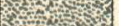

alleyalluvium.

SEDIMENTARY ROCKS

EOCENE

Roslyn formation

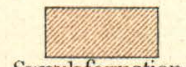

Swaukformation conglomerate)

PRE-EOCENE
(CARBONIFEROUS?)

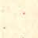

Peshastintormation (slateand grit with

IGNEOUS ROCKS

POST-EOCENE

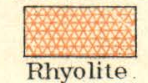

EOCENE

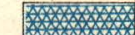

Teanawaybasalt

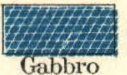

PRE-EOCENE

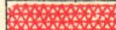

Mount Stuartoranodiorite

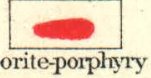

Diorite-porphy

eridotite and serpentine

Haweins formation

(breccias, tuffs, and amygdaloids)
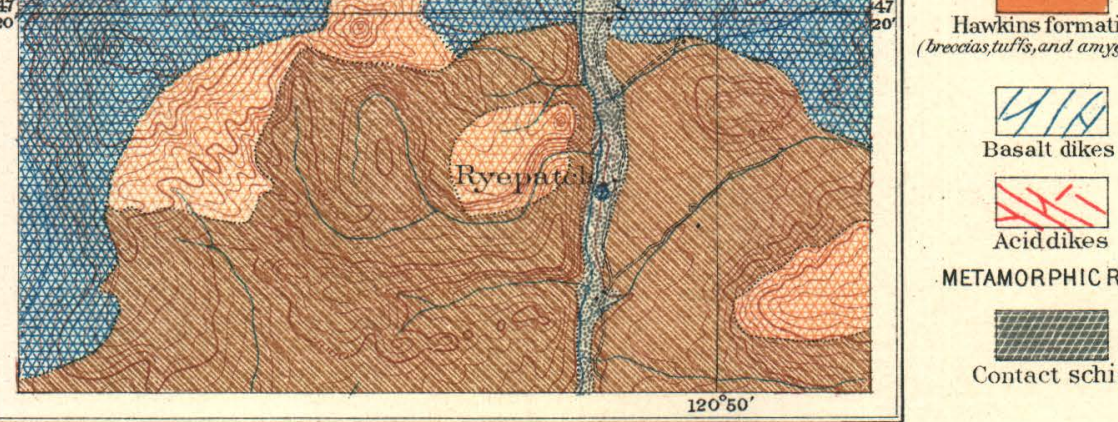

Basalt dikes

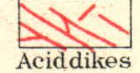

Aciddikes

METAMORPHIC ROCK

GEOLOGIC MAP OFAPORTION OF MOUNT STUART QUADRANGLE

Topography by G.E.Hyde WASHINGTON Geology by George Otis Smith
assisted by G.C.Curtis

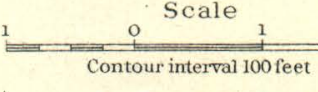
2 MILES

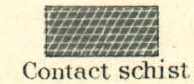


places in the area. No rock can be more varied in color or in physical characters than is this serpentine. It ranges from bright red to light green in color, and forms bold crags with gigantic talus blocks below, or rounded hills covered with fine shingle resembling broken glass.

The serpentine and older rocks in which it is intruded contain gold and copper veins. Locally such veins have been found to be very rich, but the amount of lowgrade ore far exceeds these bonanzas.

This serpentine is intrusive in the Peshastin and Hawkins formations, but is itself cut by dikes of light porphyritic rock. These latter are doubtless connected with the great batholith which forms Mount Stuart. The rock of the batholith is a typical granodiorite, often containing quartz, but too basic to be called a granite. It is a gray granular rock, quite granitic in appearance. Generally fresh and unaffected by surficial alteration, its constituent minerals can be seen to be white feldspar, black mica, and bornblende, with a few grains of quartz. The granodiorite is everywhere massive, but is jointed and sheeted, this feature giving rise to the spire and minaret details so characteristic of the crest line of Mount Stuart. Dikes of the granodiorite can be traced extending out into the serpentine, so that it is plainly the youngest of the pre-Eocene rocks.

EOCENE.

Swauk formation.-The oldest of the four Eocene formations is the Swauk formation, a series of sandstone, conglomerate, and shale, measuring in places at least 5,000 feet in thickness. The age is definitely determined as early Eocene by the fossil flora, and the basal beds are seen to be separated by a great unconformity from the formations upon which they rest. The conglomerate beds are mostly in the lower part of the section and the basal conglomerates are often peculiar in that the pebbles and bowlders are derived almost wholly from the rock upon which the conglomerate rests. Thus, the conglomerate may be composed of granodiorite bowlders in an arkose matrix or of serpentine blocks embedded in a sand of the same composition. The sandstone is for the most part arkose in character, although to the east the sediment shows better sorting and is more quartzose. The shale is often quite carbonaceous and rich in fossil leaves.

This formation is of economic importance from the gold veins it contains in the Swauk Basin. Most of the gold, however, is found in placers, but the gravels have all been derived from the Swauk formation and the gold is coarse and has not been carried far from the parent ledge.

Teanaway basalt.-Overlying the Swauk sandstone and separated from it by a slight unconformity is a volcanic formation. The Teanaway basaltic series comprises lava flows and interbedded tuffs. The basalt is black and very compact and makes a 
prominent rock. The tuffs are very irregular in their distribution and the thickness of the whole series varies within the area from thousands of feet to a few hundred.

This basalt has been termed by Russell the lowest or first sheet of Columbia River lava, but its importance in the stratigraphy of the region seems to warrant a more definite separation from the Miocene lava to be described later. The most striking feature of the Teanaway basalt is the occurrence of hundreds of dikes which cut through the underlying Swauk formation and connect with this surface flow. The opportunity is afforded for observing almost diagrammatically the evidence that these basalt flows were erupted through many' fissures, and for the most part the eruption appeared to be unaccompanied by any disturbance of the underlying rocks.

Roslyn formation.-This sedimentary formation overlies the basalt without any apparent structural break, but also without any evidence of transitional sedimentation of interbedded sands and tuffs. A few pebbles of basalt in the basal beds show that locally there may have been erosion of the lava before the sedimentary beds began to be deposited. The Roslyn formation contains sandstones and shales, resembling the earlier Eocene sediments somewhat. Carbonaceous material becomes more important in the upper portion of the formation, where there are several beds of coal. The Roslyn coal seam is of commercial importance, and excellent steam coal is mined in quantities that give the Roslyn mine the first place among the coal mines of Washington.

Manastash formation.--So far as known this formation is limited to the southwestern part of the Mount Stuart quadrangle and the adjacent portion of the Snoqualmie quadrangle. It is a series of sandstone, shale, and conglomerate beds, containing some seams of carbonaceous material, mostly bone. Fossil plants from the shales determine the age of the formation as Upper Eocene, and it is therefore to be correlated with the Clarno formation of the John Day Basin. Although these beds are somewhat younger than the Roslyn formation, which occurs a few miles to the north, the Manastash rests directly upon the old Easton schist, and this relation is believed to indicate nondeposition of the earlier Eocene sediments in this area.

MIOCENE AND LATER.

Takima basalt.-This basalt of Miocene age covers a considerable area in the Mount Stuart quadrangle and the larger part of the Ellensburg quadrangle. It extends to the northeast, east, and south of these quadrangles, and also forms a portion of the higher part of the range west of the Ellensburg quadrangle. The base of this great series of lava flows is exposed at many points in the Mount Stuart quadrangle, and the lavas are here seen to rest unconformably upon the Eocene formations. This unconformity between the Yakima basalt and the Manastash formation fixes the age of the lava as early or middle Miocene. It is, in view of 
the age determination, possible for this formation that the name Yakima has been applied to it. In earlier reports on central and southeastern Washington, Professor Russell applied the names Columbia lava and Columbia River lava to this rock. He, however, included not only the Miocene but also the Eocene and possibly the Pliocene basalts, as well as the hypersthene-andesite occurring along Naches River, which will be mentioned later as of Pleistocene age. It became necessary in course of detailed areal mapping to separate these various igneous rocks, and therefore the name Yakima has been applied to this formation, which includes only the basalt flows and interbedded pyroclastics which are of Miocene age and thus constitute a series that can be taken as a unit since it represents the products of a volcanic activity uninterrupted by any other important geological process. The Yakima basalt is a normal feldspar basalt containing the usual constituents, plagioclase, augite, and olivine. It is commonly a glassy lava, and in some localities large masses of pure basalt glass can be found. The rock is always dull in color and no.crystals can be distinguished except by means of the magnifying glass. In a few localities, notably Bald Mountain, in the. Ellensburg quadrangle, the series includes large quantities of fragmental material, the yellowish tuffs including irregular blocks of jet-black glass, some of which undoubtedly represent bombs ejected from the center of eruption. Along Yakima River the tuff beds and scoriaceous lavas are less common than the compact lava.

The number of lava flows in this series varies widely in different parts of the area. At no point is the whole series exposed. The sections shown in Yakima Canyon, where over 2,000 feet of basalt are exposed with neither the top nor base of the series visible, indicate that the actual thickness of the Yakima basalt is probably to be measured in thousands of feet, and 5,000 feet is undoubtedly a conservative estimate. The columnar structure is the most noticeable feature of the basalt where it is exposed in the canyon walls.

In a portion of the Ellensburg quadrangle slightly later flows of basalt occur interbedded with the sandstone which overlies the Yakima basalt. These have been included in the Wenas basalt, which is a formation of only local importance. Similar sheets of basalt are doubtless to be found in other portions of the great area covered with Miocene basalt.

Ellensburg formation.- The only formation in central Washington which is known definitely to be of Miocene age is the Ellensburg sandstone. Collections of fossil leaves made by Professor Russell in 1892 near Ellensburg and by myself in 1900 in Kelly Hollow have afforded material for the determination of the age of the formation, which Dr. F. H. Knowlton fixes as late Miocene. This determination correlates the Ellensburg formation with the Mascall formation of the John Day

$$
14493-\text { No. } 19-03-2
$$


Basin in Oregon. The Ellensburg formation also resembles the Mascall in its composition. Both formations are composed largely of volcanic sediments, the sandstones and shales consisting of the finely comminuted andesitic material and the conglomerates containing pebbles and bowlders of andesitic lavas. In both cases the lava from which the sedimentary material was derived is not exposed within the area where the sedimentary rocks bave been studied. This volcanic series doubtless occurs in the higher parts of the range to the west.

Along Naches River over 1,500 feet of the Ellensburg formation are exposed, and the formation is characterized by coarseness of material, together with its prevailing andesitic composition, and also the common occurrence of stream bedding. A section of this formation exposed at White Bluffs, on Columbia River, is described by Professor Russell " as consisting of "fine, thin-bedded sand and clay, with layers of pure white volcanic dust." The field evidence, therefore, indicates that in the Yakima region the Ellensburg formation is to be considered as of fluviatile origin, while farther east along the Columbia the formation is plainly of truly lacustrine type. The cross stratification or stream bedding shows that the material was distributed by eastward-flowing streams. These stream sediments vary considerably in thickness within short distances, as would be expected, and at some points the stratification is so confused that individual beds can not be traced far. At localities, both in the Ellensburg and the Mount Stuart quadrangles, - bowlders of andesite measuring at least 5 feet in diameter have been found in the Ellensburg conglomerate, proving that powerful currents must have transported the material.

Later lavas.-The lava from which the Ellensburg sediments were derived was light-colored and contained hornblende as an original constituent. Later lavas of a somewhat different type occur in central Washington. The most prominent of these is the hypersthene-andesite which forms a long lava stream extending from the Tieton Basin west of the Ellensburg quadrangle down Tieton Canyon and along the Naches Valley nearly to Yakima River. This lava was erupted after the basalt and Ellensburg rocks had been uplifted to their present positions, and at a time when the topography was essentially the same that it is to-day. The lava is, therefore, of Pleistocene age, and where not exposed to erosion by Tieton River the lava stream preserves the form which it took when it came to rest. The surface of the andesite platean between Naches River and Cowiche Creek is exceedingly hummocky and full of undrained basins, while its margins, which have been affected by stream erosion, show the radiating columns into which the lava parted at the time of its consolidation.

Somewhat different lavas occur on the middle fork of Teanaway River, where rhyolitic rock is seen to rest upon the eroded surface of the older rocks. The age of 
this lava is somewhat problematical, but evidently it is considerably jounger than the Focene rocks with which it is in contact.

Pleistocene deposits. - In the heart of the Cascade Range the valleys of the larger streams exhibit abundant evidence of glaciation. Within the area here described glacial deposits are not found except in the vicinity of Mount Stuart, which was a local center of glaciation. The valleys of Yakima River and most, of its tributaries within the Mount Stuart quadrangle are gravel filled. These valley gravels attain great prominence in the upper valley of the Yakima and plainly once filled it to a considerable height, and diamond-drill records indicate that the river has not yet reached its former floor. The gravel terraces constitute a noticeable feature here, but are much less important than similar terraces upon the Columbia, which will be mentioned by Mr. Willis. In the Swauk drainage basin these terrace gravels are auriferous and have been mined for many years.

\section{STRUCTURE.}

Certain of the structural features have been mentioned in the foregoing description of the formations. A more complete statement of what has been learned concerning the geologic structure of the region will be given here, since the area affords excellent opportunities for studying the course of events in the dynamics of the mountain building. The two quadrangles present two types of structure, but both are representative for the Cascade Range.

\section{MOUN'T STUART QUADRANGLE.}

The oldest rocks were intricately folded and faulted before the intrusion of the peridotite, and this accounts for the greater. metamorphism which characterizes the schists, slates, and greenstones. The intrusive peridotite, now largely altered to serpentine, appears to have suffered similar dynamic action, but its record of deformation is doubtless much less significant. The rock is commonly crushed and sheared, but this condition indicates rather a lack of resistance on the part of the soft serpentine than intensity of the deformation forces. In fact, in large measure, the development of the zones of sheared material within the serpentine mass may have been due to the expansion incident upon the serpentinization of the peridotite. This alteration, with the resulting crushing, is known to be pre-Eocene in age, since the bowlders with slickensided surfaces, so characteristic of the zones of shearing, are found in the basal conglomerates of the Swauk formation.

The jointing of the granodiorite is its only structural feature, since nowhere is the rock schistose. This batholithic intrusion doubtless played a considerable part in the pre-Eocene structure of the region, but no deformation of the older rocks can be definitely traced to this igneous rock, unless the hydrothermal alteration of the peridotite may be attributed to the intrusive granodiorite. The presence of small 
dikes extending from the latter rock into the adjacent serpentine shows the absence of any later differential uplift of the massive granodiorite.

The earlier Eocene rocks appear to have been subjected to deformation soon after their deposition. The folds are open, with steep inclination of the strata exceptional. Within the area south of the Mount Stuart massif, a half dozen folds may be traced, the anticlines and synclines having axes which trend northwestsoutheast. This structure, in part at least, antedates the eruption of the Teanaway basalt, since that rock lies upon the somewhat eroded folds of the Swauk sandstone. Later, however, these folds may have been further developed.

The manner in which the rocks of the Swauk formation nearly encircle the Mount Stuart massif suggests that this forms the center of a great dome-shaped uplift, with the Tertiary formations dipping outward. The areal distribution favors this simple explanation of the structure, but detailed study of the various formations makes it plain that a careful distinction must be made between the different movements that have contributed to the sum total of deformation. The attitude of the Mount Stuart massif at the commencement of the Eocene sedimentation can not be determined, except that this mass of granodiorite is known to bave furnished the bulk of the detritus for the Swauk sediments. These strata on the south side of Mount Stuart then became folded, as has just been described, and uplifted so as to suffer erosion. If the structure developed at this time may be determined by the distribution of the basaltic lavas which flowed out in the succeeding epoch, it appears that there was not only an elevation in the vicinity of Mount Stuart, but also on the eastern and the southern part of the Mount Stnart quadrangle. The rise of the Wenatchee Mountains dome does not appear to have been so prominent a feature at this time as the development of an east-west trough in the central portion of the Mount Stuart quadrangle. In this depression, the molten lavas consolidated and the tuffs were laid down, and later the Roslyn sediments were deposited, the latter formation possibly covering in its original extent an even more limited area than did the Teanaway basalt.

Clealum Ridge, which bounds the Yakima Valley on the south, has certain topographic characters suggestive of a fault searp. The structural relations show, however, that this marks the southern side of the syncline developed in the Teanaway and Roslyn formations, and its topographte prommence is due to the older rocks which rise here above the Eocene strata to the north. In middle Miocene time this ridge had much the same relative prominence, as is shown by the way the Yakima basalt abuts against and caps it, while filling the neighboring depressions. This post-Roslyn folding may have been coincident with the deformation of the Manastash strata, and thus belongs to the close of the Eocene period. 
ELLENSBURG QUADRANGLE.

The post-Miocene deformation ean be studied best in this quadrangle, where only Miocene formations are present. Yet, while pre-Miocene structures can thus be avoided here, it is necessary to distinguish between the flexing or moderate folding to which the Yakima basalt and the Kllensburg sediments were subjected soon after the deposition of the latter, from a later movement which affected the same rocks. These later structural features are so closely connected with the topographical features of the area that their discussion will be given under the heading "Physiography."

In the present connection, however, it may be well to call attention to a certain structural feature of the Yakima basalt. This is the almost universal occurrence of parting or jointing in the rock, by which the lava sheets are divided into the typical basaltic columns. This contraction parting took place normal to the surface of the lava flow, so that where the hasalt has its original position undisturbed the joints are vertical. The presence of innumerable joints of this character, of course, would greatly facilitate the flexing of the basalt sheets; and, since the Yakima basalt is the more important formation in the Yakima region, this feature must not be disregarded in any consideration of the deformation of this area. Furthermore, this may serve to explain why the post-Miocene deformation, which will later be described as taking place at the surface, was not of the nature of faulting as that term is generally accepted. The structural ridges are not "tilted blocks" but anticlines."

\section{HISTORY.}

The geology of central Washington may be best summarized by a brief résumé of the geologic history of the area.

The oldest rocks, probably of Paleozoic age, furnish a record of sedimentation and rolcanism, but this record has been greatly obscured by the altered condition of these rocks. This metamorphism in turn tells of the orogenic movements to which the rocks have been subjected and of the action of intrusive magmas.

The great intrusions of peridotite and granodiorite probably belong to the Mesozoic, and were events of the first importance in the history of this portion of the Cascade Range. The period of erosion subsequent to these intrusions was of sufficient length to allow these deep-seated bodies to be uncovered and deeply dissected.

From these eroded older rocks was derived the material for the Eocene sediments, and the process of sedimentation appears to have been a rapid one withiu this area, since several thousand feet of granitic sands and other sediments were deposited in carly Eocene time, before uplift again inaugurated erosive activity.

a This absence of faults in this area has been discussed in a recent paper by the auchor-Anticlinal mountain ridges in central Washington: Jour. Geol. Vof XI 1903 pis 166-177. 
'Then began the first basaltic eruptions, the forerunners of the greater volcanism of the Miocene. This volcanic activity was succeeded by the quieter. processes of sedimentation, by which the Roslyn sandstone was deposited in middle Eocene time. Somewhat later, in an aujacent area, the deposition of the Manastash sediments took place, and the Eocene period closed with the uplift and folding of all of these Eocene formations.

Erosion continued well into the Miocene within this area, but ceased with the beginning of the great eruption of basalt, the many flows of which covered the greater part of central Washington like a molten sea. Immediately succeeding this epoch of volcanism came the deposition of the Ellensburg formation, thick deposits of stream sands and gravels, brought down from a volcanic area to the west.

Mountain-building movements followed this sedimentation of the later Miocene, and again erosion began to cut away what had been uplifted. The. Pliocene and post-Pliocene history is recorded in the topography, and will therefore be discussed in the following chapter.

Even this brief summary is sufficient to indicate how eventful has been the geologic history. Especially in Tertiary time is it true that this region has been one with relatively many changes. The many well-marked unconformities testify to the frequency of these geologic revolutions, so that geologic formations are easily separated upon the basis of structural breaks, whereas in other provinces such subdivision would need to be based wholly upon paleontologic evidence.

\section{PHYSIOGRAPHY.}

\section{TOPOGRAPHIC DESCRIPTIONS.}

MOUNT STUART REGION.

Mount Stuart, 9,470 feet high, lies 15 miles east of the main crest of the Cascade Range, and forms the culminating peak of the Wenatchee Mountains. These mountains constitute a secondary range transverse to the general trend of the Cascades, but are characterized by the same rugged topography as the main range. The mountain crests are deeply carved into spires and crags, while precipitous slopes descend into glacial amphitheaters where remnants of glaciers still persist. South of Mount Stuart, and extending almost to Yakima River, there is a belt of hardly less rugged topography. Here the valleys are deep and canyon-like and the divides are sharp and narrow. Dissection has apparently reached the extreme limit, and the topography may be termed mature. The gradient of the streams is largely determined by rock hardness, and many of the minor topographic features, such as peaks and gaps in the crest lines of ridges, are also referable to varying resistance of the different rocks. Pl. III is a map. of a portion of the Mount Stuart quadrangle, showing the topography typical of this area. 


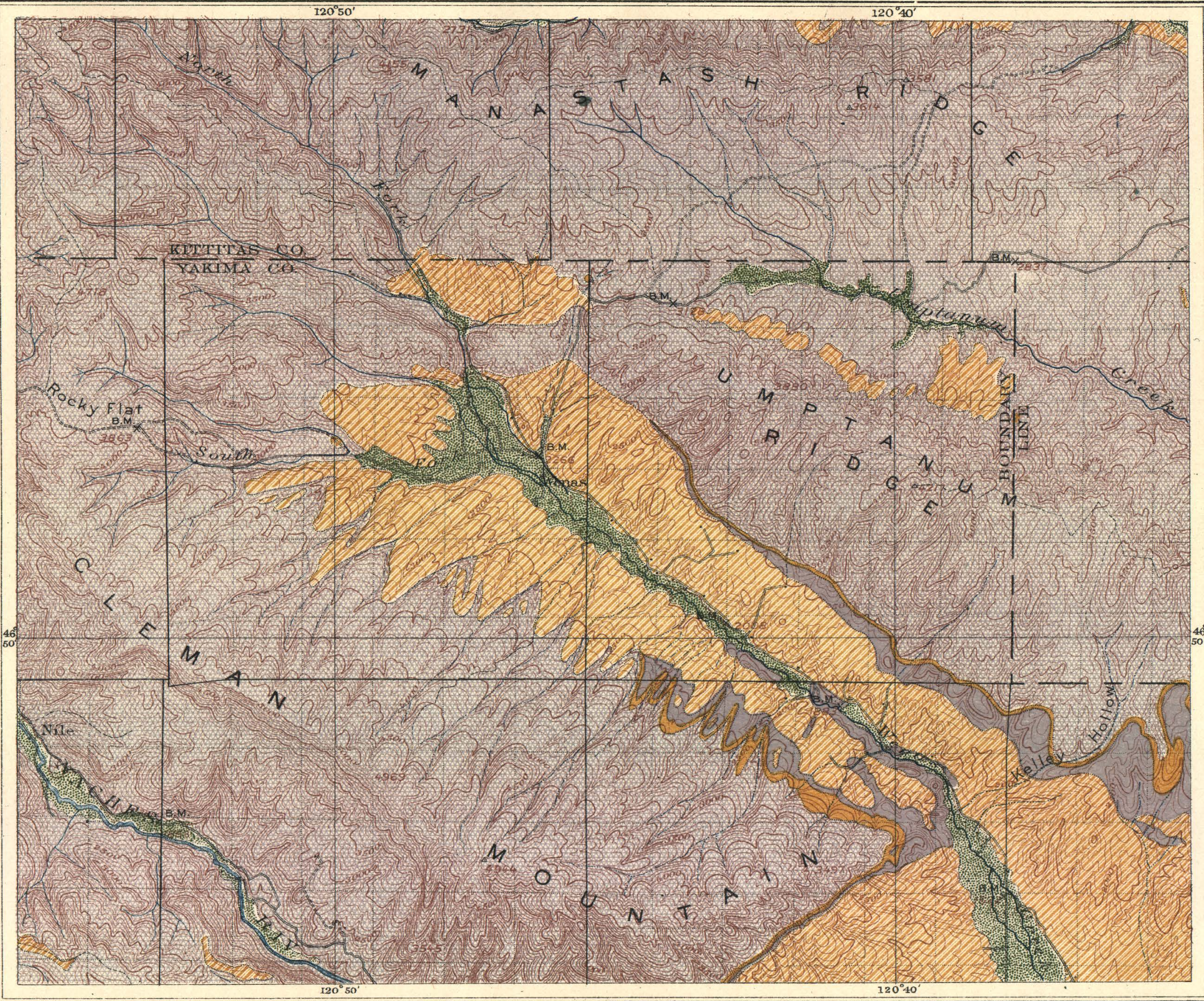


The southern part of the Mount Stuart quadrangle includes an area quite distinct in its topographic features from that described above. Here there is a transition into the type of topography characteristics of the Yakima region. While the streams may have canyons similar to those farther north, they are farther apart. The divides are broad and comparatively level topped. The valley of the Upper Yakima forms the dividing line between the two areas, and the surface geology is also quite different on the two sides of this valley, in the vicinity of Clealum. On the south the prominent escarpment of the Yakima basalt overlooks the river and on the north are the lower ridges of Eocene sandstone. However, the differences in topography are not wholly due to the geology, as will be shown in a later section of this paper.

YAKIMA REGION.

That part of Yakima County. which lies adjacent to the course of the river of the same name possesses a topography that is unique. Its origin will be fully discussed in the following pages, so that only a brief description is necessary here. In its general features this topography is very simple. Long canoe-shaped valleys, with intervening ridges, form a quite constant succession with the general trend transverse to the course of Yakima River. Some of the valley floors reach the river level while others lie several hundred feet above the bottom of the river canyon. The ridges rise from 1,000 to 3,000 feet above the valleys, with fairly gentle slopes and even crests, except where interrupted by the deep water gaps of the river. The relation of these ridges and valleys to the river may be seen in the sketch map of Yakima Canyon (Pl. VI); and the topography of a typical portion of the region is given with more detail in PI. V. PI. II shows very well the character of Yakima Canyon where it cuts through Manastash Ridge.

This description of the topography would be incomplete without mention of the landslides that are common in central Washington, a topographic form fully described by Prof. I. C. Russell in several papers. The active canyon cutting and favoring geologic structure has caused this area to afford wonderful examples of landslide topography. One of the best of these is on the southern slope of Cleman Mountain, and is well represented on the physiographic map (PI. V). These landslides vary in size from some to be measured by cubic miles of displaced rock to others involving less than an acre of surface. In age this range is scarcely less striking, certain landslides antedating the high terrace gravels deposited when glaciers occupied the Upper Yakima Valley, while other slides are of so recent origin that vegetation has not yet gained a foothold. 


\section{CASCADE LOWLAND. $a$}

\section{IDENTIFICATION.}

As was noted in the discussion of the literature, Professor Russell finds in the plateau-like surface of the Cascade Mountains evidence of previous reduction of the region "to a plain, or an approximately plain, condition nearly at sea level." This was the "Cascade peneplain," the subsequent elevation of which resulted in the "Cascade plateau." In view, however, of the complete dissection of this plateau into a complex of sharp ridges and peaks, as described by Russell, it is evident that both plateau and peneplain are somewhat hypothetical. A general uniformity of altitude of the ridges and peaks of the central portion of the Cascades may be made out in certain districts, but so frequently are other peaks seen which rise above this level that this class of evidence taken alone is far from conclusive. Indeed, this is best appreciated by those who have been most earnest in their search for traces of the old peneplain. Furthermore, the date of the supposed planation has not hitherto been determined even approximately.

The identification of possible remnants of the old lowland, if such a lowland existed, becomes most essential to the investigation of the later history of the Cascade region. By reason of the aridity of its climate and consequent slight erosion the conditions in the area along the lower course of Yakima River are most favorable for the preservation of land forms. Erosive activity is mostly confined to the larger streams which head in areas to the north and west where the precipitation is greater. Under such conditions it appears quite possible for deformation to outstrip erosion, with the result that the relation between structure and topography becomes at once both close and obvious.

At first glance, the topography of this Yakima region is seen to be dependent upon structure. The ridges are anticlinal and the valleys synclinal. This relation necessarily involves a more or less perfect parallelism between the surface and the rock structure. The parallelism may or may not be easily observed, but the determination of the degree of this conformity between structure and surface becomes of the greatest importance.

The first hypothesis to suggest itself in the course of the field work in the northern part of the area here discussed was that the anticlinal and monoclinal ridges bounding the extensive Kittitas Valley were in a great measure pre-Ellensburg. This valley with its floor of Ellensburg sandstone, horizontal or only gently inclined upward at the borders, has the general features of a structural basin in which lacustrine sediments have been deposited. Such a view would involve an unconformity -

a Cascade is here used purely in a geographic sense. To express the period of development of this lowland, Mr. Willis's term " Methow" would be more exact, and its use becomes necessary in his more detailed discussion of the suecessive stages in the history of the Cascade Range. 
between the Mrocene lava and the succeeding sediments, and the Ellensburg formation would be found to occur only in the synclinal basins where it had been deposited. Further study of the area, howerer, showed that the distribution of the Ellenshurg formation is too general to permut of its being considered a local deposit of the character suggested.

The second explanation to be tested in the field was that the soft sandstones had been eroded from the crests and higher slopes of the anticlinal ridges, the Ellensburg thus being left only in the lower parts of the synclinal valleys. This apparently was the opinion held by Professor Russell in his reconnassance of the Yakima region On this supposition, it was not pre-Ellenshurg but post-Ellensburg movement that uplifted the anticlinal rulges of the area. Subsequent to the warping of the surface of the Miocene sediments, crosion removed the softer beds fiom the ridges, which determined the general distribution of the Miocene rocks as now observed, the upfolded basalt forming the ridges, and the Ellensburg sandstone occurring in the valleys between. In this way there was a perfect conformity between surface and structure, although with a subsequent destruction of this orginal surface, except in the floors of some of the basins or valleys, where the whole thickness of the sedimentary formation may have been preserved. The level tops of the ridges, therefore, while not preserving the original surface, would be parallel to it and in a way represent it, since the sheets of resistant basalt parallel to the original surface have determined the present surface.

This second hypothesis also had to be abandoned because field evidence did not support it. The essentral feature of conformity between surface and structure was found to be wanting, so that it became evident that the true explanation is less simple. Where the even surface is best preserved, on the level crests of the ridges and on the long, gentle, and smooth slopes along the flanks of the same ridges, it is apparent that this surface does not parallel the underlying lock structurc. The dip of the rock and the inclination of the slope agree in drection but differ in amount. The rock dip commonly exceeds the slope, and higher beds occur in the valley than can be found on the rudges, and while such valleys may be unsymmetrical with regard to the slopes on either side, the rock folds are even less symmetrical.

Tracing the rock slopes of the valley sides upward until the even crests of the ridges are reached, lower sheets of the basalt are successively crossed, until it is evident that the crests of the anticlines have suffered considerable erosion, so that the highest heds are found in the synchnal valleys and the lowest on the crests of the anticlinical ridges. The result has been more than the crosion of the softer sandstone strata from the ridges and their preservation in the neighborng valleys. The surface is thus an enosion product and cuts across both the folded Yakima basalt and Ellensburg sandstone. 
This beveling of rocks as widely different in their resistance to erosion as the hard, compact basalt which withstands the attacks of stream corrasion and the soft friable sandstone easily eroded even by the desert winds is especially noteworthy in connection with the present discussion. The absence of any scarp or other topographic form expressive of differential resistance of the two rocks indicates a long continuance of the crosive activities producing this surface. Such perfection of planation could not be expected much short of reduction to a baselevel, so that the natural deduction from these observed facts is the former presence of an essentially level lowland over the area. Therefore, the third hypothesis was adopted in the field, namely, the ridges and valleys of the Yakima region represent a warped lowland surface. The relation of this surface to the rock structure is not a simple one. The reduction of the area of previously folded rocks to a lowland caused any perfect conformity between the surface and the structure to be very exceptional, while on the other hand, the general or approximate parallelism between the two as observed at many points becomes explicable from the fact that the warping of the lowland surface was in the main along lines coincident with the axes of prelowland folding. This double deformation resulted in steeper dips for the rock strata, which were subjected to both movements, and more gentle inclination of surface slopes which have been affected only by the later warping.

DEVELOPMENT:

The extent of this Cascade lowland and the degree to which it was developed may next be considered. In the Yakima region exceptional conditions favor its preservation, and the recognition of this physiographic feature is easy. Detailed mapping reveals the fact that the Cascade lowland was, in this area at least, a comparatively perfect one. Remnants of the old lowland now uplifted on the flanks of the anticlinal ridges are seen to have a remarkably uniform surface. On the sketch

- map of a portion of the Ellensburg quadrangle (PI. V) are indicated the portions of the old lowland surface that have escaped destruction by later erosion. In the field the evidence appears much less fragmentary than on the map. The narrow gulches that score the sides of the ridges are unsuspected when one looks along the slope. What is seen is a gently inclined featureless surface extending from the even crest of the ridge to the valley floor below, often without a perceptible break. This surface is commonly covered with basaltic débris, usually quite coarse, which has been derived from the basalt exposed in the immediate vicinity. On some very gentle slopes a thick deposit of fine silt is found. Whether or not this may represent a lowland deposit can not be definitely stated, but its present distribution is in part due to wind action.

On this planation surface it is often impossible to trace the contact between the 


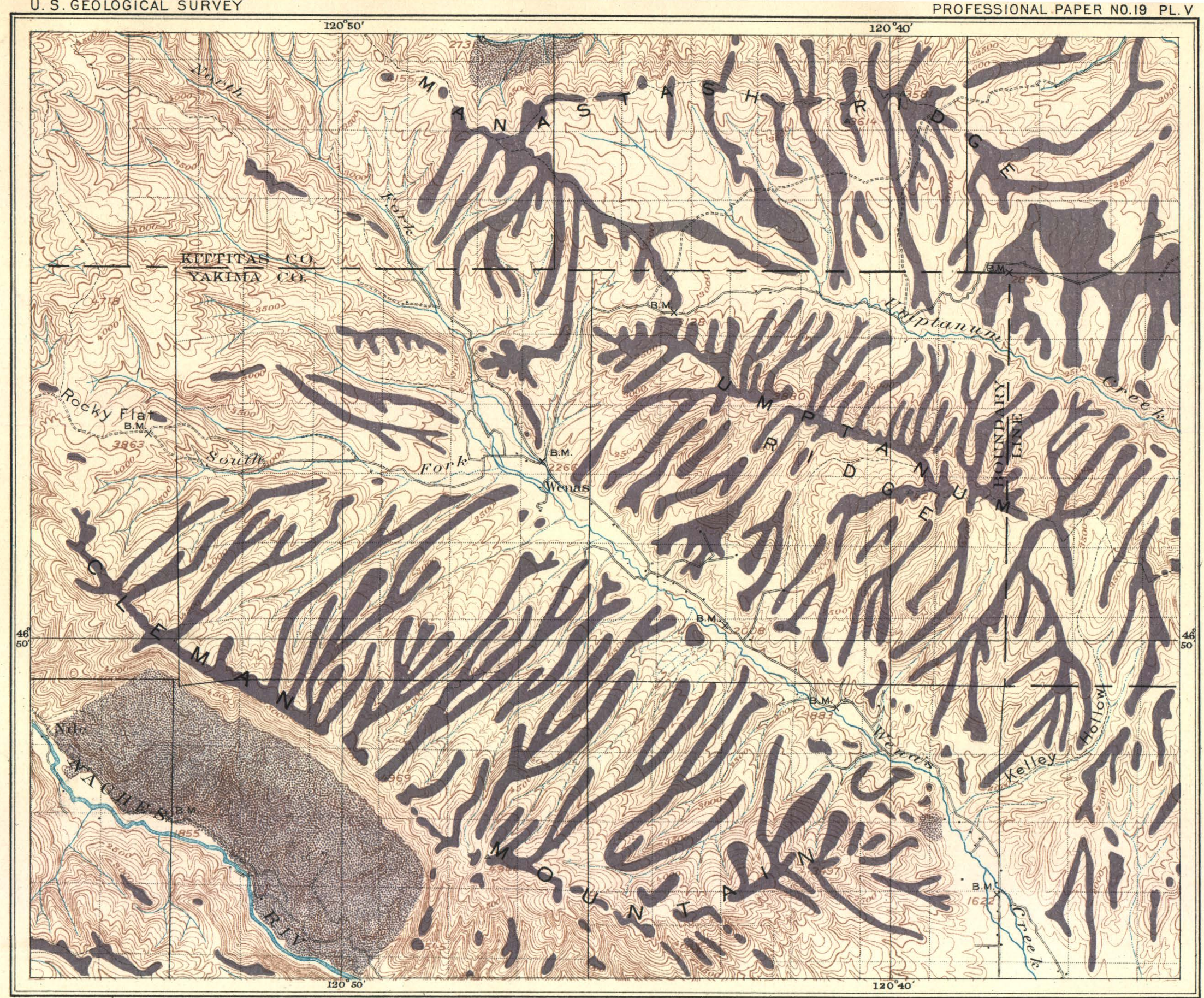

LEGEND

HN

Remnants of lowland surface

Landslide area

PHYSIOGRAPHIC SKETCH MAP OFAPORTION OF THE ELLENSBURG QUADRANGLE, WASHINGTON

Toposraphy by A.E. Murlin

Scale 5 miles 
two formations. The accompanying illustration (fig. 1) shows such a case, and is drawn from a photograph of the spur east of Kelly Hollow on the southern slope of Umptanum Ridge. This may be considered the type locality for the recognition of the lowland surface. The plateau is several hundred yards in width and over a mile in length, and preserves its even surface to the very brink of the steep-sided gulches that bound it on the east and west. The surface is thickly strewn with angular bowlders of basalt, and there is not the slightest indication of the contact between the Yakima basalt and the overlying Ellensburg sandstone. On either side, however, on the walls of the gulches the position of this contact can be accurately fixed and its dip seen to be $20^{\circ}$. Here, then, the planation was complete and the resultant lowland surface is perfectly preserved.

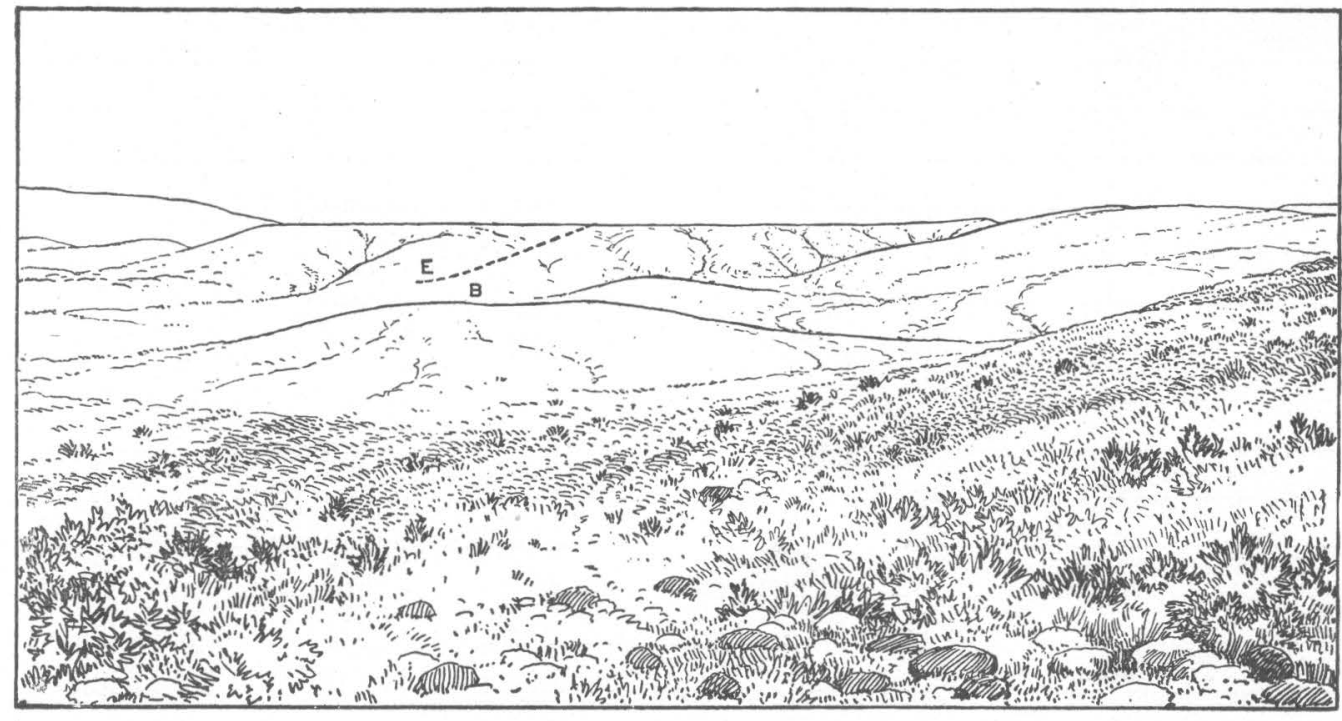

FIG. 1.-Contact of Ellensburg sandstone and Yakima basalt-E, Ellensburg; B, Basalt.

The profile of the deformed lowland, with the relation of this surface to the rock structure, is well shown in the section on Pl. VI. This section extends from Ellensburg to the vicinity of North Yakima, and while in a general way it is parallel to the accompanying map, it was made to follow as far as possible the unmodified spurs between the gulches that have been cut into the slopes. It represents, therefore, as well as a true section can, the lowland surface now warped to form the ridges and valleys of this area.

On the slopes of Manastash Ridge, Umptanum Ridge, Cleman Mountain, Cowiche Mountain, Selah Ridge, and Atanum or Yakima Ridge remnants of the Cascade lowland can be detected. Farther north, in the Kittitas Valley, the old surface may be recognized on the slopes of Table Mountain and of Lookout Peak, where the inclination of the surface is seen to be less than the rock dip, in the sloping surface of 
the even-topped terrace of Ellensburg sandstone along Yakima River, and in the flat-topped mesa of similar material near the Normal School Building in Ellensburg.

The identification of the old lowland surface becomes more difficult outside the area here described. Eastward, undoubtedly it can be traced to the plain of the Columbia, and to the northeast the even surface of Table Mountain appears to be continued in the even-crested but lower ridges just. south of the mouth of Wenatchee River. Table Mountain thus 'serves to connect physiographically the Yakima region with the area described by $W$ illis in the second part of this paper. North of Lookout Mountain, in the Mount Stuart quadrangle, as may have been inferred from the description of the topography, there are no traces of a peneplain surface. In the western portion of the Ellensburg quadrangle, where the ridges mentioned above unite to form a broad plateau, the distinction can not be made with certainty between the old surface and a possible later erosion feature, which may be determined by the gentle monoclinal structure of the basalt. Especially is this true on account of the absence of the Fllensburg sandstone and the consequent lack of the best criterion for the recognition of the old lowland surface.

The evidence of the reduction of a large area of folded Tertiary rocks to form the Cascade. lowland appears conclusive. The date of the development of this lowland is fairly well determined, since folds involving late Miocene strata are truncated, while on the other hand the subsequent history of a large part of the region has been so eventful that the production of the lowland surface could not reasonably have been later than Pliocene. Previous to this Pliocene reduction, erosion does not appear to have ever produced anything like a peneplain in the northern Cascades, as far as its history has been determined. In view of the eventful character of the whole of the Tertiary, it is plain that the period of reduction to base-level can not be considered as including any large part of. Tertiary time, as bas been suggested by Russell. Uplifts or subsidences of the extent that are known to have occurred during Focene and Miocene time in this area must be considered as inaugurating new topographic cycles. Furthermore, the land surface that was flooded by the basalt flows at the beginning of the Miocene possessed considerable relief. This pre-Miocene topography has been preserved in a large measure from later erosion by the basalt, and where the capping is partially eroded away and stream canyons are eut down into the underlying formations the contact shows very conclusively. the character of the old surface. Such a locality is the valley of Taneum Creek, where it is at once seen that the prebasalt surface was such as to deserve to be termed rugged topograpby. It seems necessary, therefore, to restrict the period of the development of the Cascade lowland to the Pliocene. ${ }^{a}$

a It is of interest to note that in the John Day Basin, Merriam finds evidence of the erosion of the upturned $M$ Iiocene formations early in Pliocene time: Bull. Dept. Geol. Univ. California, Vol. II, No. 9, p. 311. 
CASCADE PLATEAU.

CHARACTER OF TIE UPLIFT.

'Russell's term, "Cascade plateau," is used in this paper as a convenient designation for the uplifted lowland surface. The term is of value as expressive of the change in attitude and as descriptive of the mass from which the Cascade Range has been carved. It is not, however, to be inferred that a broad, unmodified table-land once existed where now there are rugged peaks and deep canyons. The uplift was not catastrophic but slow and gradual, and further knowledge of its character may be gained from the study of the Yakima region.

Here, as has been noted in the previous section, the uplift was effected with pronounced deformation along well-defined axes, producing parallel ridges. This evidence in the region where the upraised surface has been so preserved that definite conclusions are possible suggests that the uplift of the Cascade Mountains was not necessarily of a broad and general character, producing a dome with gentle slopes extending over thousands of square miles, but that the uplift was effected with similar local warping in other parts of the Cascades.

This may serve to explain the lack of uniformity in elevation of some of the higher peaks. - Such cases are cited by Russell, ${ }^{,}$and he suggests four hypotheses to explain the greater prominence of the granite peaks, of which Mount Stuart is a type. The postpeneplain elevation of such masses is rejected on the ground that the structure antedates the period of reduction to base-level. Another hypothesis is that these high peaks represent monadnocks on the old lowland, and another that the higher peaks, being composed of the more resistant granitic rocks, more nearly preserve the original general surface level of the Cascade plateau, which was about 10,000 feet above sea level, while the peaks of softer rocks have suffered a general diminution in height. A fourth hypotbesis "calls for local upheavals since the Cascade peneplain was raised into a plateau and subsequent to the initiation of the present master drainage lines," $b$ an upward movement which is thought possibly to be still in progress. This last hypothesis appears to Russell to best explain the observed facts, and a modification of this may be here suggested in light of the later observations in the Yakima region.

The uplift of the Cascade lowland to form the Cascade plateau on the present supposition was not a simple, broad, flat-topped, anticlinal uplift, but a deformation of more complex character. The Wenatchee uplift was not necessarily a local uplift subsequent to the main Cascade uplift, but rather a part of that uplift and contemporaneous with the localized deformation in the Yakima region. The Wenatchee Mountains are thus comparable to Manashtash and Umptanum ridges to the south, and may, indeed, form the higher part of a somewhat broader uplift, 
of which the Table Mountain-Lookout Peak ridge, 20 miles south of Mount Stuart, forms the lower flank. On the Wenatchee Mountains apparently no remnant of the old lowland surface remains, although such a surface is suggested by the level platform from which the upper 1,500 feet of Mount Stuart rises as a monadnock, but on Lookout Peak and Table Mountain such a surface can be detected extending down into the Kittitas Valley, as noted above. It must be kept in mind, however, that such an uplift in no sense explains the rock structure, which greatly antedates this surface deformation, but, like the cases cited in the Yakima region, the later uplift was apparently along an older structural axis, and it is only by detailed study of the basal contacts of the different Tertiary formations that the distinction can be made between Eocene deformation and the . deformation which followed the post-Miocene reduction to a lowland.

VARYING DEGREE OF DISSEOTION.

In the brief description of the topography of the Mount Stuart and Yakima regions the difference in type was pointed out. The variation in degree of dissection is at once apparent. This is in no sense due to differences in the formations eroded, but has its origin in climatic conditions. On the eastern flank of the range the precipitation is scanty and erosive processes correspondingly weak. Only the larger streams that head outside the arid belt accomplish much, so that deformation has been able to quite outstrip erosion, with the result that the warped lowland surface is preserved. On the higher slopes, especially nearer the crest of the range, the precipitation is greater, and active erosion has resulted in mature topography.

It is on account of this deep dissection that there is little remaining to more than suggest the Cascade plateau over large areas in the Cascade Mountains. Whether or not the acute peaks even approximate the old surface can not be determined, but it seems probable that in the higher portions of the range there has been a general diminution of height.

The cause for variation in degree of dissection other than that of a climatic nature is the length of the period during which erosion has been uninterrupted by crustal movement. In one area the topographic cycle may be continued from youth to old age, while in another region not far distunt, in the same time, one cycle may be terminated and another inaugurated simply by a local uplift. The physiographic stages enumerated by $\mathrm{W}$ illis in his puper have not been differentiated in the foregoing description of the central Washington area. It is doubted, moreover, if such distinctions can be made generally throughout this area, by reason of its physiographic development differing from that of the region described in the following paper. This difference appears possible, and indeed probable, since in the 
case of gaps cut by Yakima River in ridges only a few miles apart the record in one case is shown to be that of an uninterrupted uplift of the ridge, while the compound form of the other gap shows a balt in the uplift sufficient for widening the canyon in its earlier portion.

A few points of connection between the two regions may be noted, however. The greater part of the Mount Stuart and Ellensburg quadrangles lies outside the limit of glaciation, and therefore direct reference of the date of topographic features to a glacial episode becomes difficult. The period of development of the Cascade lowland as described for the Yakima region of course corresponds to the Methow stage of Willis. The Entiat stage is poorly represented in the Mount Stuart quadrangle, and the only traces of topography antedating the present are found in the old valley of Camas Land and in several small areas now capped by rhyolitic lava, the pre-lava surface plainly. possessing only moderate relief. Elsewhere in the northern half of this quadrangle dissection appears to have proceeded so far as to destroy all evidences of an earlier stage, while in the Yakima region these later stages have not been separated, the uplifted Methow topography having suffered extremely little modification. Since the physiographic development is the result of the interplay of earth forces and atmospheric agencies, it is evident both must remain the same throughout a region to result in the same succession of physiographic stages. Climatic differences appear to account for much of the topographic diversity, but the structural history is no less important. It would seem futile, therefore, to expect uniformity in the physiographic record over wide areas in a province like the northern Cascades if the writer is correct in his belief that the uplift of the range has been complex rather than simple. However, it is no less evident that the more complete record that can be deciphered for the one area is of material value in the understanding of the other area.

There is good reason to expect confirmation of the views here expressed in the course of future work. Already the writer has detected remnants of the uplifted lowland surface in higher portions of the Cascades. The Cascade plateau was also found to be exceptionally well represented immediately north of Mount Baker, near the international boundary. Here there is not only a marked uniformity in the elevation of the ridges, but their crests are broad and even. Such topographic characters belong to an older topography, and it is believed therefore that these features in reality mark the preservation of the lowland surface now uplifted to form the plateau with an altitude of over 5,000 feet. This plateau is incised by the deep canyons of Nooksak River and its tributaries, while upon it rests the volcanic cone of Baker. West of this region, toward the crest of the Cascades, the plateau character is lost and the more complete dissection makes the topography one characterized by the most acute peaks and rugged mountain masses. In this higher portion of the 
uplift the attack by crosive agencies has plainly been much more severe, and erosion has outbalanced deformation with the resulting destruction of the plateau type of surface.

RIVER HISTORY.

In the higher parts of the Cascade Mountains it will probably be found that the only line of evidence bearing upon these physiographic problems is that furnished by the streams. The antecedent character of such streams as the Icicle, which cuts across the granite mass of the Wenatchee Mountains, bas been recognized by Russell, and furnishes additional proof of the existence of the Cascade lowland. In considering the history of such streams and their relations to the rock formation across which they have cut their canyons it is most important that a sharp distinction be made between the rock structure and the surface warping. The former is the result of successive epochs of dynamic action preceding the Pliocene lowland reduction, while the latter comprises the elevation of the Cascade lowland to form the Cascade platenu or the uplift of the Cascade Mountains.

In the Yakima region where the lowland surface is best preserved the history of Yakima River, as it can be traced out, corroborates the physiography as stated in the earlier section of this paper. The antecedent character of this river is at once apparent, and, as noted in the review of the literature, Russell was the first to call attention to this important feature. As can be seen from examination of Pls. II and VI, the Yakima crosses the high ridges in a deep canyon in which the original meander's of the river are strikingly preserved. The course of the river antedates the uplift of these ridges, and the warping of the lowland surface must have been effected at a rate that permitted the Yakima to maintain its course without change. That there was no damming sufficient to cause the stream to seek a new channel is shown very conclusively. in the vicinity of North Yakima. The river leaves the broad transverse valley in which that city is situated by cutting through Atanum Ridge at Union Gap, which is nearly a thousand feet deep. Five miles east this ridge has a low saddle, purely structural in origin, which affords an easy pass less than 200 feet above the valley floor. Here, had there been any ponding of the Yakima waters during the uplift of the ridge, the river would surely have discovered the lowest point in the rim of the basin; but there is no trace of stream occupation of the pass. At other points where the Yakima cuts through other ridges the relations are hardly less convincing, since often the water gap interrupts the ridge in its highest part.

The surface upon which this course of Yakima River was established plainly must have been the Cascade lowland. The independence which this course shows of the hard and soft rocks which made up that lowland points to the development of the meanders on a surface on which there had been a perfect reduction to base-level. 


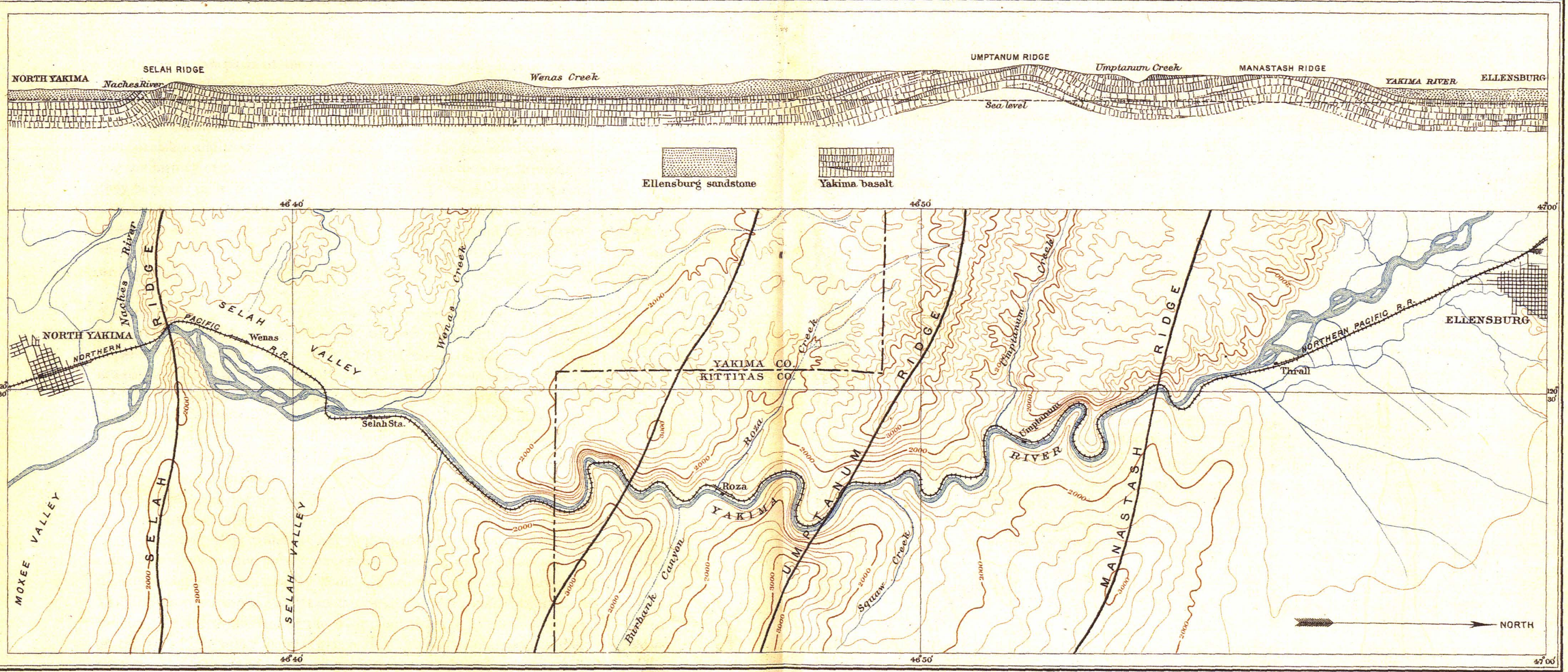

SKETCH MAP OF THE YAKLMA CANYON, SHOWING POSITION OF ANTICLINAL AXES WITH PARALLEL GEOLOGIC SECTION, SHOWING RELATION OF WARPED SURFACE TO STRUCTURE BY GEORGE OTIS SMITH

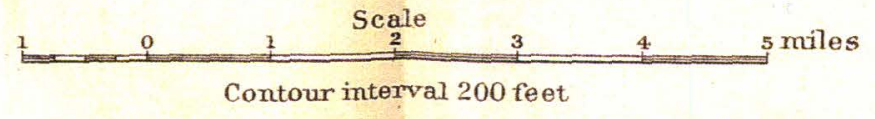


Furthermore, the manner in which the lowland surface cuts across folds involving the Miocene sandstone indicates that the course of the Yakima was not determined, at this time at least, by the slope of the uplifted lake bottom, as suggested by Russell. Here, again, the later warping must be distinguished from the earlier folding of the rocks.

Naches River, the most important tributary of the Yakima, is plainly also of antecedent character, since it has cut diagonally across one of the anticlinal ridges, uniting with the main river near the axis of the ridge (Pl. VI). The smaller tributaries of the Yakima in this region appear to be generally synclinal in position and also consequent upon the warping of the lowland. This statement, however, needs modification, since in the cases of Wenas and Selah creeks portions of the streams cut across minor ridges. Selah Creek also flows along the north side of Selah Valley in a canyon the brink of which is above and over a mile distant from the axis or lowest part of the valley. Such a relation may be taken as showing that the course of the' stream is antecedent to only a portion of the warping of the lowland, the axis of that deformation having shifted southward. Wenas Creek is peculiar in that while it flows along the rather broad valley between Umptanum Ridge and Cleman Mountain and may be considered a synclinal stream, its shallow canyon is cut along the axis of a low anticline. This fold shows both in the rocks, the basalt appearing in the canyon, and in the deformation of the surface. The geologic and topographic relations of the Wenas Valley can be seen on the map of this area (Pl. IV). Back from the creek on either side is a parallel valley across which the seasonal streams flow before joining the creek. The old lowland surface can be traced from the slope of the ridge across the back valley and up on the flat-topped hills overlooking the main creek, and the fact that basalt bowlders cover these hilltops where the underlying rock is sandstone shows that this is the lowland surface. At one place the back valley has so level a floor that a stream coming down from the ridge sometimes divides on its alluvial fan and flows out to the creek through two separate canyons. The explanation of these relations that presented itself in the field was that Wenas Creek was at first a synclinal stream in the valley between the two ridges, but by a later uplift of the low ridge along the center of this, valley the creek cut down through the sandstone into the basalt beneath. There is evidence, too, that this later warping followed a structural line marked out at the time of the prelowland folding. The uplift of this medial ridge, a movement not exceeding 300 feet, was so gradual that not only did the main creek maintain its course but the tributaries suffered no changes, but crossed the unaffected back valley and cut steep-sided gulches through the uplifted ridge. A simultaneous and indeed connected uplift also occurred a few miles up the valley, where the two

$$
\text { 14493-No. 19-03-3 }
$$


northern branches of the Wenas cut across an arch of basalt. The structure here can be seen perfectly in the canyons, and the flat crest of the ridge well expresses the lowland surfaces; and here again the absence of conformity between surface and structure is noticeable. This history of Wenas Creek is simply an incident, of little importance except as it may show that the warping of the Cascade lowland was not a simple, uninterrupted movement, in some localities at least.

An interesting problem in connection with the history of the Cascade Range will be the identification of the system of antecedent drainage of which Columbia, Yakima, and Wenatchee rivers appear to be important parts. It will be at once noticed that these master streams are in no sense consequent upon the broad Cascade plateau with its north-south trend, as described by Russell, nor altogether upon such minor uplifts as have been thus far recognized. These rivers are the streams that controlled and effected the reduction of the post-Miocene land surface to a peneplain, and the study of this drainage system may yield some data bearing upon the degree to which the planation was carried and upon the position of monadnocks and important divides. The extent to which it is justifiable to apply this hypothesis of the deformation of the old lowland surface into local domes or ridges, features measuring a few miles in shorter diameter, rather than into a broad plateau uplift measuring hundreds of miles in extent, can then be better discussed.

PHYSIOGRAPHY OF THE SNOQUALMIE QUADRANGLE.

Since writing the foregoing portion of this paper the author has extended the geologic mapping westward from the Mount Stuart area. The Snoqualmie quadrangle, which was surveyed in 1902, lies within the heart of the Cascade Range, and includes about 50 miles of the main divide between the Puget Sound drainage and the streams tributary to the Columbia. Such a region appears to furnish an opportunity for testing the wider application of the conclusions reached in the adjacent area. In the Ellensburg quadrangle erosion has been insufficient to destroy the traces of the Pliocene peneplain, now warped into the ridges described in the preceding pages. In the Snoqualmie quadrangle land sculpture has plainly reached a stage in which no traces of such a peneplain can be recognized. The topographic cycle is nearing maturity, and while the problem of interpreting the physiography is more difficult, it becomes interesting to make the test and to attempt to determine for this portion of the range the type of uplift which inaugurated the present cycle of erosive activity.

' As a preliminary to this, it is helpful to review certain of the general principles of land sculpture as first and most clearly defined by Powell and Gilbert. These will be briefly stated in so far as they apply to the question in band, which is, What was the character of uplift of this central portion of the Cascade Range? Such general principles may be stated thus: 
Degradation is controlled by declivity, rock structure, and climate. As will be seen below, the second and third factors may be omitted in the present consideration. While of great importance, they are essentially without value as criteria in this instance. Degradation, including erosion, sapping, and corrasion, as well as transportation, increases with declivity.

The work of ordinary degradation may be greatly augmented by glaciation, which, as will be noted later, was not universal in this area, hence glaciation has value for the purpose of this discussion.

In the case of the simple uplift of a broad arch, there would result a flat top and steeper flanks. On the steeper flanks the greater declivity would determine the locus of the more effective degradation. With consequent streams, therefore, the maximum rate of degradation would obtain along the flanks of the arch, and at any stage there would result an axial ridge with axial peaks as the highest portion of the uplifted area. This result may be stated differently, following Gilbert: There would be a persistence of divide, since at first it was the divide because an eminence, and later an eminence because the divide.

If the elevation was so slow in its first stages as to enable degradation to keep the axial region practically reduced, the resultant form would have a plateau character, as Powell has pointed out in the case of the western portion of the Uinta uplift. There, however, the axial region is higher, although its prominence is inconsiderable when compared with the whole amount of degradation.

With antecedent streams there is not the same persistence of divides, but rather a change due to the tendency of the streams to become more and more consequent. As developed by Campbell, the law of this migration of divides is that the divide tends to migrate toward an axis of uplift and away from one of subsidence. Thus it follows that in the case of a warped peneplain the antecedent drainage would tend to adjust itself to the warping and the streams would come to occupy the axes of relative depression with divides located upon the axes of elevation. In the case where the axis of depression shows changes in direction of pitch there would also be the tendency for the point on this axis, marked by divergence of pitch, to become also a divide.

Now, turning to the Snoqualmie area, certain facts of observation may be stated, as they apply to the problem under discussion.

The main divide of the Cascade Range within this quadrangle is wholly upon Miocene rocks, with the exception of 2 miles, where it is close to the contact of the Miocene with the Eocene. The highest peak on this divide, which bas an altitude of 7,512 feet, and the lower portion of the divide for a considerable distance-with an altitude of 3,500 to 4,500 feet-are composed of Miocene volcanic rock with essentially the same physical characters. For this reason it appears evident that, as was stated above, rock character is not at all a controlling factor. 
Climatic conditions are more or less uniform over this area, and any differences are dependent upon relative altitude, which in turn is involved in the question of relative uplift which is being discussed. Climate nust therefore be left out of the discussion, and it is plain also that it would not have any important bearing on the final decision.

In the Lower Yakima region, where the river was antecedent, it was shown that the rate of uplift of the transverse rudges was not essentially more rapid than the rate of corrasion. The uplift, however, was greatly in excess of ordinary erosion, since many remnants of the uplifted surface remain. In the central region Yakma River carries its low-grade valley well back toward its head, so that the rate of uplift here has not been much greater than the maximum rate of corrasion No actual remnants of the old surface, however, are known in this mountainous region, so that while degradation has far from kept pace with uplift, it has been efficient enough to produce a topography that has many characteristics of maturity. The question of the antecedent or consequent character of the drainage again depends upon the main question.

As can be seen on the accompanying map of the Snoqualmie quadrangle (Pl. VII), in which only the 500-foot contour's above 5,000 feet are shown, the trend of the higher portions of the area is slightly north of west. The main divide has a general trend of a few degrees east of north, so that the difference in trend is approximately 90 degrees. Further, it will be seen that the high peaks on the divide are where it is crossed by these east-west heights.

The streams in the vicinity of the outlying heights are fully as efficient as those near the main divide, and in many cases possess the advantage of shorter courses and steeper gradients.

The thick mantle of soil which is of common occurrence in the lower divide region must be taken as strong evidence of the inefficlency of transportation here as compared with the higher country.

Glacial erosion has been an important factor in the northern area, characterized by a greater topographic prominence, while glaciation has been wanting in the lower parts of the main divide.

As the third part of this section, the foregonng general principles and particular fucts may be brought together and certain conclusions deduced. This process will constitute the wider application of the hypothesis based upon the work in the Ellensburg quadrangle. The deductions are as follows:

(a) Whatever the rate of uplift, the axial region should exhibit some topographic prominence. If uplift has outstrupped degradation, as is the case in this area, the axial ridge must be a distinctive feature

In fact, the main divide in the Snoqualmie quadrangle fails to show any such prominence, except as was noted above. Therefore it is not the axial region. 


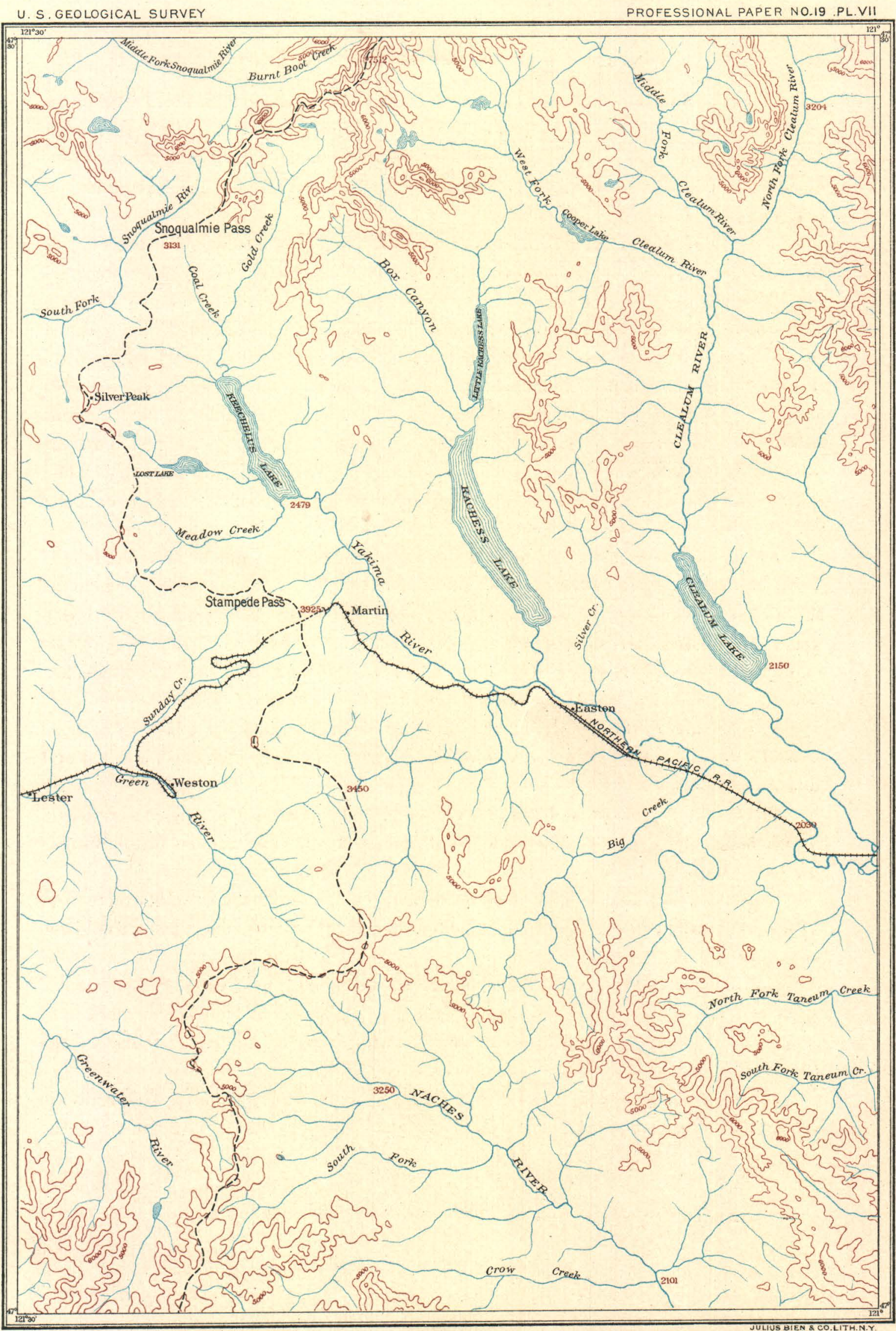

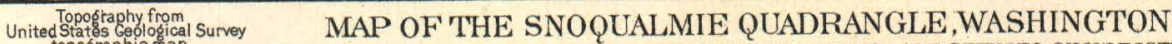

CONTOURS OP 5000 FEET AND ABOVE, WITH 500-FOOT INTERVAL, ARE GIVEN TO SHOW DISTRIBUTION OF HEIGHTS WITH REFERENCE TO MAIN DIVIDE OF CASCADE RANGE

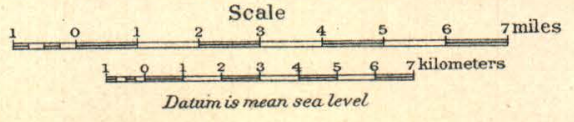


(b) Uniformity in present altitude of neighboring heights is suggestive of preexistent uniformity, even if not exactly indicative of the actual position of the older surface. A line connecting closely adjacent beights, even although these are separated by canyons representing the work of efficient stream corrasion, is expressive of the position of an axis of uplift.

In the Snoqualmie quadrangle the position of three such axes of uplift may be approximately determined. The southernmost of these extends beyond the boundaries of this quadrangle, both east and west from the divide. Next, northward, is the high ridge between Naches and Yakima rivers, which is topographically and, in part at least, structurally the continuation of Manastash and Umptanum ridges to the southeast, which are known to represent upwarps of the old peneplain. Likewise, the third line of heights along the northern edge of the Snoqualmie quadrangle connects with the prominent Mount Stuart mass which constitutes the axial portion of the supposed Wenatchee upwarp of the lowland surface. These three lines of heights, which thus possess marked topographic prominence, are believed to indicate the position of three upwarps of the lowland surface.

How nearly the present surface on these heights represents the old surface thus uplifted can not be so definitely stated. On the highest portions of the Naches-Yakima ridge the level tops are strongly suggestive of the old surface. The uniformity in the present altitudes is a striking feature of the northwestern portion of the area, as illustrated by Mr. Willis on Pl. IX, and this uniformity may reasonably be considered the result of a general reduction of these tops, which has been relatively slight in amount.

(c) In whatever degree the system of divides fails to accord with the deformation, the drainage system shows similar lack of consequence. Streams cutting across lines of uplift must be antecedent, in part at least, and, with antecedent streams, the divides may be in process of migration.

In the Snoqualmie quadrangle the main divide has been shown to be not coincident with the axis of most marked surface deformation. Near the northern edge of the quadrangle the divide makes a sharp turn to the east and continues this northeastern trend for several miles beyond the boundary of the area described here. This trend coincides more nearly with the axis of uplift indicated by the east-west line of heights.

In the lower country of the Ellensburg quadrangle Yakima River is known to be antecedent to the warping of the peneplain and Naches River to be antecedent in a portion of its course and consequent in other portions. The history of the Puget Sound streams has not been studied.

It appears evident, then, that these two master streams may also have a mixed character in the Snoqualmie quadrangle. The Naches system is for the most part 
consequent upon the two upwarps shown by the elevated ridges, and a relatively high portion of the divide is at its head where the downwarp between these two upwarps dies out. The most important tributary of the Yakima, Clealum River, appears to head somewhat north of the northern axis of uplift and is in that case antecedent. The Upper Yakima itself, however, plainly occupies an area of relative " depression and receives consequent streams from the slopes of the upwarps to the north and south. There is some evidence, however, of partial inconsequence, but the position of the main divide which parallels for about 10 miles the upper course of Yakima River appears to be in part determined by the cross axis from which this downwarp pitches.

A drainage system consequent upon complex warping of this character is thus less symmetrical than one consequent upon a broad arch. The partial inconsequence expresses simply the effect of the antecedent character of these streams which was partially preserved wherever the rate of uplift or warping failed to be the determining factor. In general, however, it is quite possible that much of the antecedent drainage may have been consequent upon prepeneplain structure, which was paralleled by this later warping, so that in the following cycle the antecedent streams have maintained their courses which may also appear to be consequent upon the warping.

The degree of agreement of the drainage with the surface deformation may furnish data for the separation of the uplift of the Cascade Range into distinct stages, as well as a more exact differentiation of the upwarps that constitute this uplift.

(d) The ultimate deduction is that, whatever the relative proportion of antecedent and consequent character in the drainage system, the main divide for the greater portion of its length in this area neither coincides with nor parallels the axes of most marked deformation of the preexistent surface. The uplift to which the Cascade Range owes its origin was not simple in type, but complex; and within this area can be resolved into three well-defined upwarps, which, moreover, are transverse to the main trend or major axis of the range considered over the larger area to the north.

\section{RÉSUMḰ.}

In the central Washington area detailed mapping has given data for the recognition of a lowland surface, the fixing of the age of its development as Pliocene, the suggestion of the drainage system which controlled that reduction to a peneplain, and the determination of the kind of deformation to which this lowland surface was later subjected. Such evidence has its bearing upon the broad problem of the origin of the great plain of the Columbia and the Cascade Range. To the east, deformation of the lowland has been less marked, while on the other side erosion has largely destroyed the uplifted peneplain. Future investigation may be productive of 
corroborative evidence over a larger area. The evidence in hand, however, is believed to be sufficient to prove the youth of the Cascade Range and to suggest that the general type of its uplift may have been complex rather than simple.

The data furnished by this study of the genlogy and physiogiaphy of central Washington may also have a bearing upon broader problems. The eventful character of Tertiary history in this province is noteworthy, as showing the rapidity with which geologic processes may accomplish their work. The Eocene section measures not less than 10,000 feet in thickness and is divisible into four distinct formations, separable both by physical breaks and by differences in fossil floras. In the Neocene period not only was there the great volcanic activity and the later deposition of the Ellensburg sediments, but also widespread deformation and the production of an extensive peneplain were effected.

Another feature of general interest is the deformation this peneplain has subsequently suffered. The evidence is belièved to be conclusive that the old lowland surface has been warped so as to form anticlinal mountain ridges and synclinal valleys. Elsewhere no such striking instance of pencplain modification has been describerl, and this unique character of the area is doubtless to be attributed in part to the structural characteristic of the jointed sheets of basalt involved in this deformation. Connected with this warping of the peneplain is the antecedent chanacter of Yakima River, which serves as an exceptionally fine example of that type of stream in that it has mantaned its course across not only one but several uplifted ridges.

A thind principle that demands recognition is the importance of separating the results of two or more distinct periods of deformation. In this way only can there be any tuue interpretation of structure in cases, such as the Yakima region, where the later movement largely followed the axes of earlier folding. Subsequent work in the Cascade Range has strengthened the belief that such persistence of structural lines through successive epochs of defor mation is not at all exceptional and must not be overlooked.

The results of this physiographic study promise to greatly faclitate future work in the northern Cascades, but they have also been presented here with the belief that they contribute somewhat to our understanding of peneplains and therr subse. quent modification, with the resulting difficulties attending therr recognition and 1dentification. 

CONTRIBUTIONS TO THE GEOLOGY OF WASHINGTON

PHYSIOGRAPHY AND DEFORMATION OF THE WENATCHEE-CHELAN DISTRICT, CASCADE RANGE

BY

BAILEY WILLIS 



\section{0 N T E N T S.}

P'age.

(1)

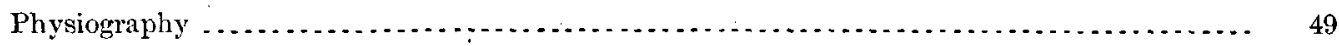

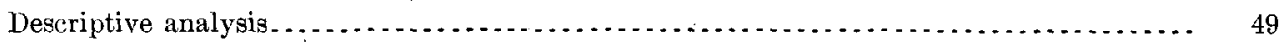

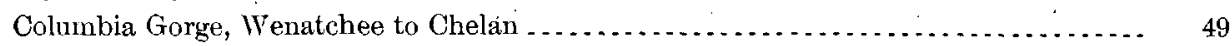

Columbia Canyon ...........

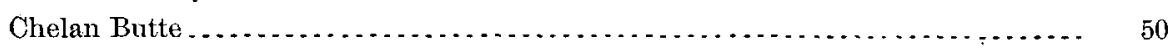

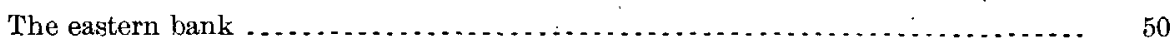

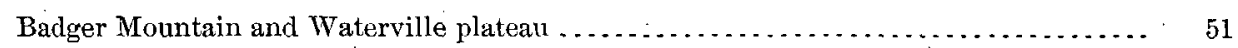

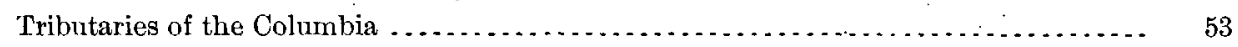

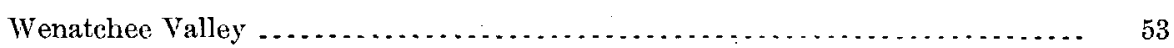

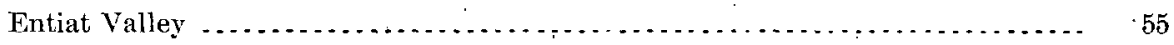

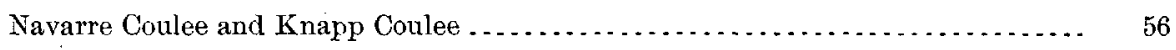

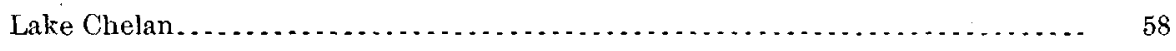

Entiat Mountains . . . .

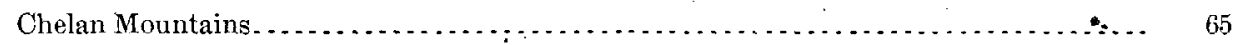

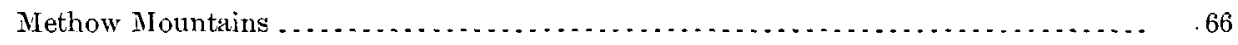

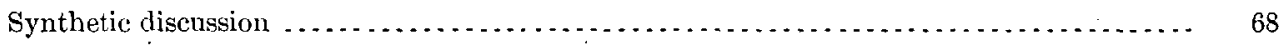

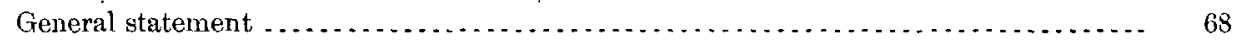

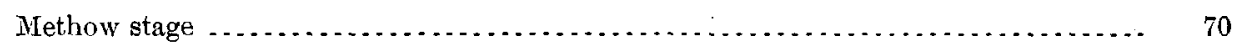

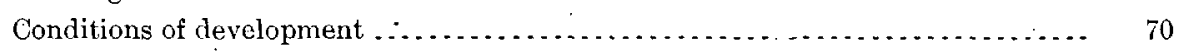

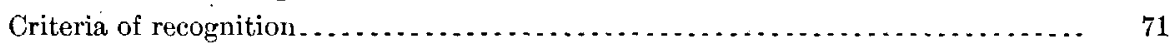

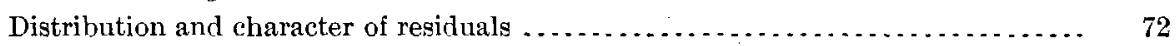

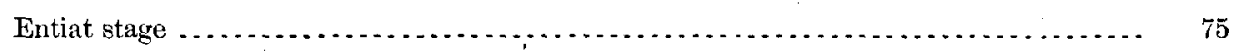

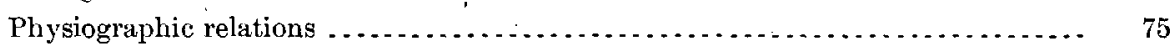

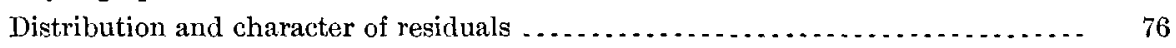

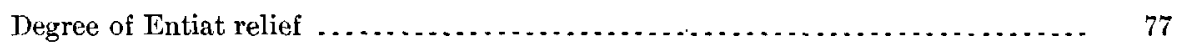

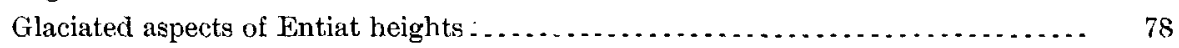

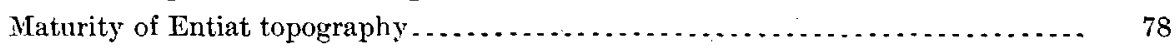

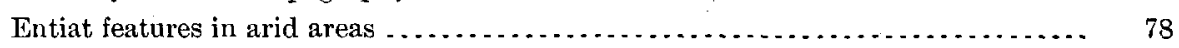

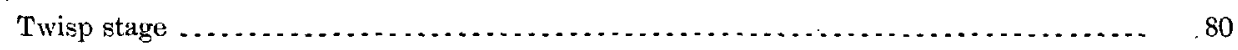

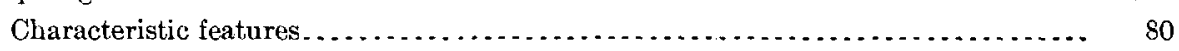

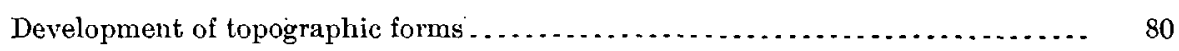

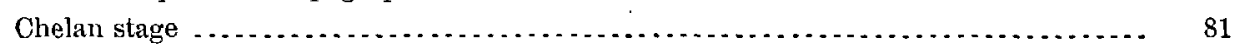

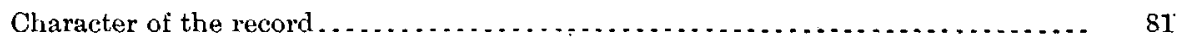

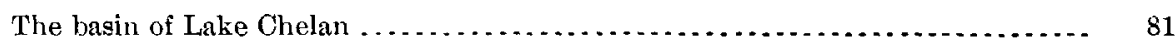




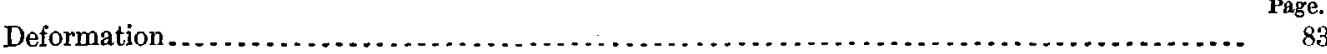

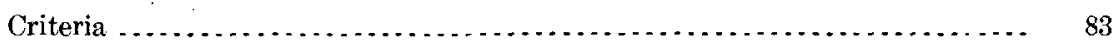

Fundamental propositions .................................... 84

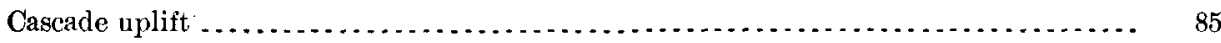

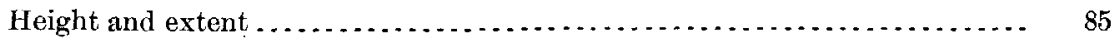

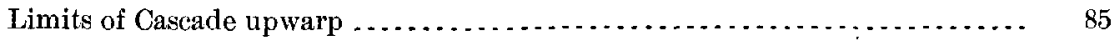

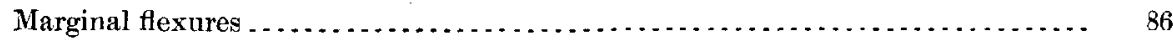

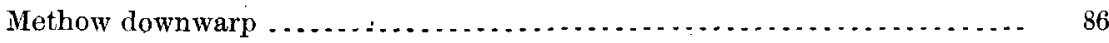

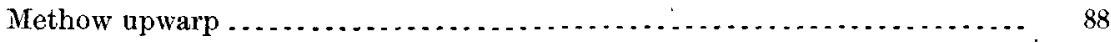

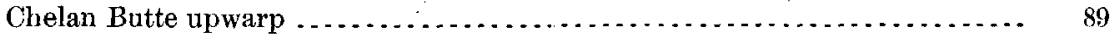

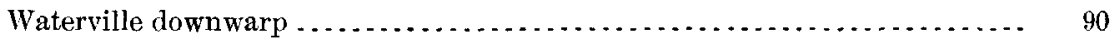

Badger Mountain upwarp...................................... 90

Wenatchee downwarp and upwarp............................... 91

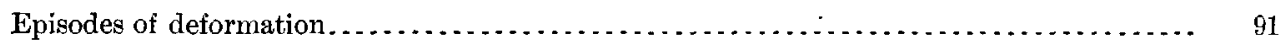

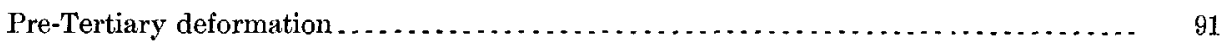

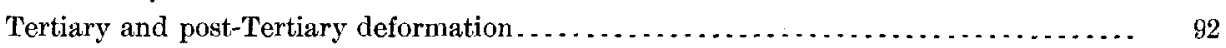

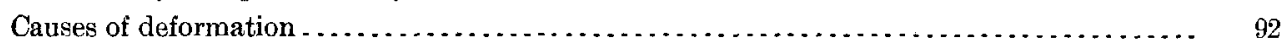

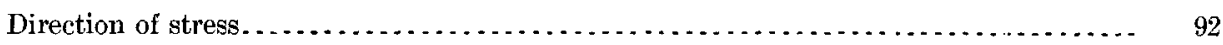

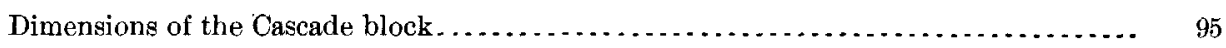

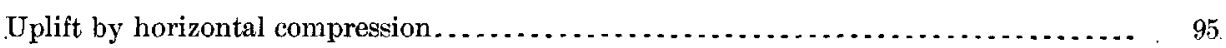




\section{IL L USTRATIONS.}

Plate VIII Map of Wenatchee-Chelan district, Cascade Range ........................

IX View of the high Cascades from head of Gold Creek, showng the uniformity of altitudes

$\mathrm{X}$ View of the high Cascades from near Cascade Pass. showing the unirormity of altitudes

XI View of Navarre Coulee

XII Chelan Butte from the north shore of Lake Chelan.....................

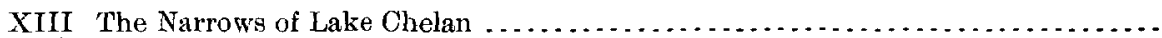

$\mathrm{XIV}$ View trom Chelan Butte, looking southwest down the Columbia Valley .........

XV View from Chelan Butte, lookıng northwest over lowe Lake Chelan to Stormy

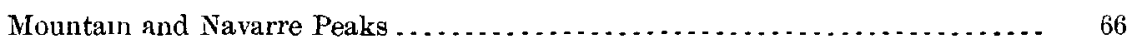

XVI Physiographic map of the southern half of the Chelan quadiangle ........... 72

XVII Physlographic map of the northern half of the Chelan quadrangle ............ 74

XVIII Physiographic map of the southern half of the Methow quadrangle ........... 76

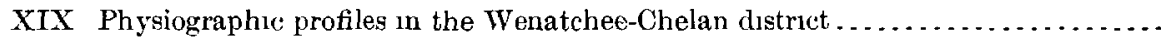

XX Views near Cascade Pass $A$, The southern slope of Boston Mountan, showing inclined joint planes, $B$, The pinnacles southwest of the pass, show ing vertical

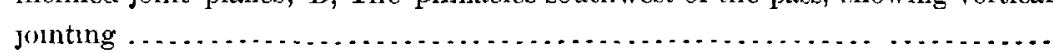

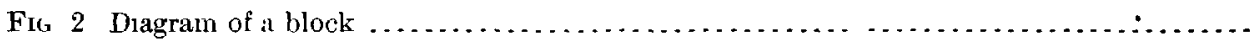

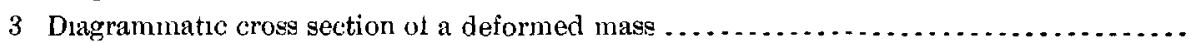

54

56

60

62

64

66
72
74
76
78

94

96

97 



\title{
PHYSIOGRAPHY AND DEFORMATION OF THE WENATCHEE-CHELAN DISTRICT, CASCADE RANGE.
}

\author{
By BaIley Willts. \\ INTRODUCTION.
}

The following article is based on observations made during several excursions in the Cascade Mountains from 1895 to 1900 , inclusive, and upon discussions with Messrs. I. C. Russell and George Otis Smith, to both of whom the writer is much indebted. When engaged in exploration in the same province, between 1881 and 1884 , the writer took little note of the physiographic aspects as such; to him they were then scenic aspects only, and impressive grandeur was the dominant idea they left. But upon returning in 1895, after eleven years spent in the Appalachians, the case was different. Association with Gilbert, Davis, Hayes, and Campbell in the discussion of physiographic relations of the eastern region prepared the observer to see the less evident, but not less definite, facts of the western province.

In 1895 the writer traversed the western slope of the Cascade Range from Mount Rainier to Skagit River, visiting especially Snoqualmie Pass and Monte Cristo. At the former place the diversion of Snoqualmie River by a moraine dam is a conspicuous fact. The former eastern course leads by a wide valley to Lake Keechelus, but the diverted stream is now cutting a precipitous canyon in the western slope. The discovery of fossil leaves, classed as Miocene by. Knowlton, in graphitic slates in the crest of the pass suggested the post-Miocene uplift of the range. Near Monte Cristo wide general views were obtained, which swept the sky line from southeast by south and west to northwest, and it was apparent that many jagged peaks rose approximately to uniform altitudes, which might reach or fall little short of an ancient plain. Stratigraphic studies of the Puget group of Eocene and Miocene strata led the writer tentatively to assign this hypothetical plain to a late Miocene date, and to place among the latest events of the Miocene epoch the uplift by which the old lowland was raised to a position at or above the summits of the Cascades. 
To test the validity of these inferences, during succeding years the heights and slopes of the range were viewed from many points, and the intersecting lines of sight, leaping from peak to peak at nearly uniform altitudes, were thought to define clearly the general attitude of the ancient plain. Among the panoramic views upon which this hypothetical reconstruction of a vanished surface was based may be mentioned that from the eastern side of Mount Rainier, at 7,500 to 10,000 feet above sea, looking east and north; that from a spur (6;000 feet) of Huckleberry Peak at the head of Gold Creek in the northeastern corner of the Snoqualmie quadrangle, tracing the sky line throughout the entire circle except from northwest to north; that from Stormy Mountain ( 7,219 feet) in the Chelan Mountains in the western quarter of the Chelan quadrangle; and that from Boston Mountain (8,300 feet) north of Cascade Pass at the head of Stehekin Valley.

In the meantime, in 1897-98, Russell reached the conclusions expressed in a preliminary paper on the geology of the Cascade Mountains in northern Washington a in the following terms:

"After the time of long-continued erosion referred to above, when the Cascade region in northern Washington was reduced to a peneplain, there came a time of elevation, when the peneplain, or a very large portion of it, was bodily raised some 7,500 feet at least, and thus became a plateau. In a broad view of the region this Cascade plateau may be considered as of the nature of a broad, flat-topped anticline, or, as Dana would probably have called it, a geanticline. 'The rocks composing this uplifted region had previously been folded, but we are justified in assuming, on what may be said to be general principles, that renewed movements occurred along these old structural lines. The main change was a general rise of a region of some 10,000 or 15,000 square miles. The total area affected was much greater than this, as the Cascade plateau extends both north and south of the field under discussion.

"One of the most remarkable features in the relief of the Cascade platean is the seeming nearly level character of its original surface. The uprising was effected without pronounced tilting. Perhaps, when our knowledge is more extended, it will be found that this conclusion is too hasty, but at present, from a study of the distribution of the rivers, as well as of the heights of the peaks left by erosion, it does not seem that the, plateau had a decided, if any, inclination toward either the east or the west. This is the most marked difference between the Cascade plateau in northern Washington and the Sierra Nevada. The Sierra Nevada, as we now find it, is the result of the erosion of a tilted plateau, bordered on the east, from Owens Lake to Mono Lake at least, by a great belt of branching fractures and faults. No such belt of fractures and displacements parallel with either border of the Cascade plateau is known. The evidence is that the rise from each side of the plateau to its nearly flat summit portion is gradual."

Among the services rendered the writer by George Otis Smith was that of wellmaintained skepticism in regard to recognition of an ancient plain over the Cascades. 
He asked for demonstration, which was difficult, since the suggestions of panoramic views failed to convince, but during his field work of 1900 he himself supplied the evidence of the existence of an old base-level plain on the hills of Yakima Valley, as stated in the first part of this paper. Of these results the writer was aware when he took the field in August, 1900, and he has found them of much value in tracing out physiographic relations in the vicinity of Lake Chelan. It would seem that the principal episodes in the history of the Cascade Mountains may now be stated with confidence.

In the field work of 1900 the writer was fortunate also in having the company

- of Prof. R. D. Salisbury, and statements concerning the glacial phenomena were suggested chiefly and often wholly by his observations and interpretations; but he is not responsible for the form in which they may here appear. The profiles which illustrate this article are drawn from topographic maps of the Chelan and Methow quadrangles, surveyed by Messrs. Griswold and Farmer, topographers of the United States ${ }^{\circ}$ Geological Survey. The writer has traversed much of the region with their maps in hand, and places confidence in the excellence and detailed precision of their work.

\section{PHYSIOGRAPITY. DESCRIPTIVE ANALYSES.}

COLUMBIA GORGE, WENATCHEE TO CHELAN. COLUMBIA CANYON.

The broad flood of Columbia River emerges upon the valley about Wenatchee from a noble gateway in the Entiat Mountains. The elevation of the river is somewhat less than 700 feet above sea. On the east the slopes of Badger Mountain rise to 4,200 feet, from which altitude the long, even profile of the summit declines gently eastward; on the west of the stream peaks of the Entiat Mountains in sight attain 5,700 feet, and these are the foothills of the Cascades. These heights of 3,500 to 5,000 feet that thus hem in the river spring from a flood plain one-half to threequarters of a mile wide, and the profiles swing upward in convex curves, steepest near the foot. The effect combines grace and grandeur, the wide river, the broad gorge, and the great mountains harmonizing in their proportions.

Such is the view from a little distance. Upon entering the gorge the observer who follows the road along the western bank feels more closely shut in. On the one hand it is but a leap into the dark-green river swirling past fallen blocks of gneiss; on the other the cliff is near, and its crest, 1,000 to 1,800 feet above, is impressively high. The boldest profiles occur from 4 to 7 miles above Wenatchee, and one conspicuous point-Ribbon Bluff-with precipitous face projects into the gorge 12 miles farther upstrean, 3 miles above the mouth of Entiat River.

$$
\text { 14493-No. } 19-03-4
$$


Cliffs are not, however, the most characteristic features of the gorge. Along the eastern side they do not occur conspicuously, and even on the bolder western side they give place frequently to steep slopes in which rocky ledges project sharply through scanty grass and sagebrush. These steeps terminate above in points of long spurs, which rise westward with gradual slope to the highest summits of the adjacent mountains. The prominent angle between the steeper and gentler elements of the profile is an important physiographic feature, upon which broad deductions are based.

CHELAN BUTTE.

Looking upstream from near Ribbon Bluff, the view includes a summit higher than its fellows on the west bank and peculiar in the long sweep of its spurs in a concave curve from the top to within 800 feet of the Columbia, where the slope breaks off into the gorge. This is Chelan Butte (3,892 feet), the eastern end of a ridge which lies between the Columbia and Lake Chelan. Its graceful profile presents the first view had from within the gorge of those higher topographic elements which lie between the mountain tops and the steeps that shut in the river. . The fact that this profile descends from Chelan Butte to within 800 feet of the river, whereas in the Entiat Mountains it ends 2,400 feet above the stream, is an index of the relative amount of recent uplift in the two places.

The graceful silhouette of Chelan Butte is broken near the extreme summit by sharp, rocky ledges, which support a narrow but flattish crest. They are formed by granite dikes cutting the softer gneiss. Peaks of this partially cliff-girt form occur isolated but dominant among the mountains west of but near the Columbia, and will hereinafter be referred to as monadnocks upor the Methow plain, ${ }^{a}$ the remnants of which, so far as recognized in this region, will be described later.

THE' EASTERN BANK.

The eastern side of the gorge differs markedly from the western. Not only is it in general not so bold of profile, but the forms of the slopes are genetically distinct. For a few miles above Wenatchee the bluffs on the east of the river almost equal those on the west in height and boldness where they rise to Badger Mountain; farther upstream, however, the slope recedes gently from the river, and, growing steeper, ends 2,000 to 2,300 feet above the stream in a mural escarpment 150 to 300 feet high. This wall crowning the height is the edge of a sheet of basaltic lava whose darkbrown color and columnar structure give it emphatic value in the otherwise gray and tawny landscape. In general the summit is even and nearly level, it being the western margin of the plateau of eastern Washington, and the line of the escarpment

a Cascade plateau, the term used by Russell to designate the surface which might be restored over the Cascade Range, would be used as the name of the peneplain, but its prior use (1872) to denote a stratigraphic series renders it unavailable. Methow peneplain is therefore here applied, from an important spur of the Methow Mountains, in which the old level is well exhibited. 


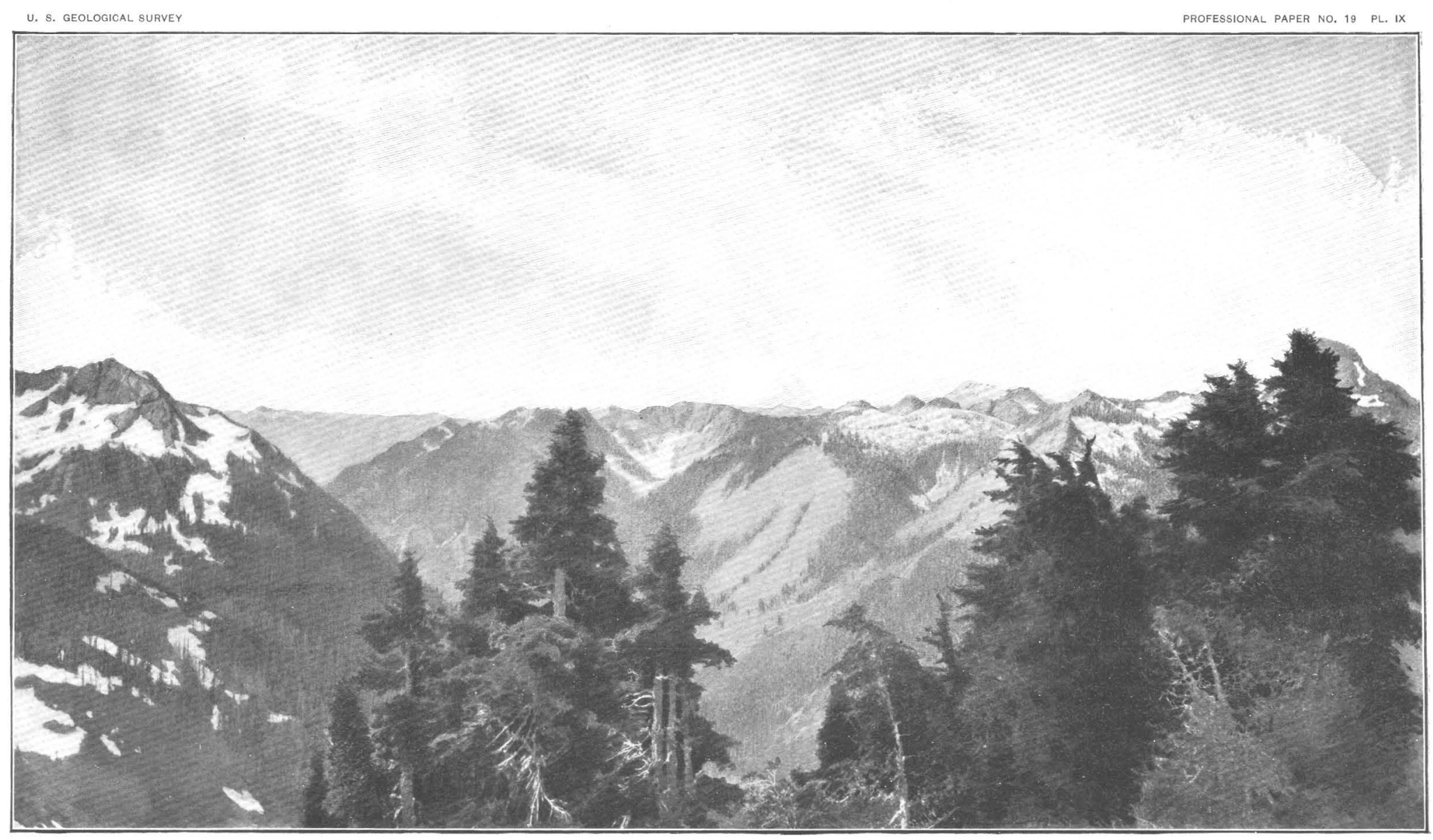

VIEW OF HIGH CASCADES FROM HEAD OF GOLD CREEK, SHOWING UNIFORMITY OF ALTITUDES, 
is in sympathy with other level lines that cross the slope at various altitudes. Some of these lines are terraces due to landslides, others in ravines are terrace-like embankments that may be traced to the work of glaciers, and others much more continuous and nearer the river are stream terraces of the great Columbia itself. These last are represented on the western side of the gorge also.

Among the features which in any complete account of the region should be fully described are the several types of terraces of this eastern side of the gorge-the landslides, most common where the heavy columnar mass of basalt weighs upon the underlying schist and granite; the ice-built terraces, which are in part effects of tiny glaciers that gathered in the shaded lee of the platean, in part results of occupation of Columbia Canyon by a tongue of a large glacier which, descending from the north, flowed down the river to a mile below Chelan Ferry; and the river terraces that extend for miles along the stream, their even tops sloping down its course and their perfect embankments rising near Chelan Ferry as much as 600 feet above the water. But all these features belong to a chapter of the history which is herein touched only incidentally-the very recent episode of glaciation.

BADGER MOUNTAIN AND WATERVILLE PLATEAU.

In its great sweep westward, southward, and southeastward across Washington Columbia River marks out the central plateau of the State. Most elevated near its western margin, this highland slopes in a general way east and southeast, and it is diversified both by channels and by uplands. The former, such as Grand and Moses coulees, appear to have been canyons of a large stream, probably the Columbia, but they are now nearly dry. The uplands are elevated portions of the plateau, connected with the lower parts by continuous slopes, usually not distinguished by scarp or steep.

Badger Mountain and the Waterville platean are parts of this central district, situated at its extreme western margin and separated from the easte: $n$ foothills of the Cascade Range only by the canyon of the Columbia. It will appear later that there is in fact no separation in the sense that the mountain district west of the river has had an orogenic history different from that of the plateau east of it. But the rock structures and conditions of sculpture are so unlike that the two provinces appear at first sight to be physiographically and geologically distinct.

In the vicinity of Waterville the plateau presents an undulating surface, with a maximum but very local relief of 200 feet in a tenth of a mile. Well-defined but shallow drainage channels converge southeastward from a flat divide at 2,900 to 3,000 feet above sea. They constitute the headwaters of Moses Creek, which soon falls into a newly cut ravine. There was no water in any of the head strearns in August, 1900 , and the flow is not only intermittent but never large. The surface is deeply 
mantled with fine soil, derived from decay of the underlying basalt. Active corrasion would quickly gully and remove it. The surface forms are rounded and filled out by blown material, showing that wind rather than water is now the efficient modeling agent; yet the landscape as a whole presents relief due to stream work.

In the flat spaces about the margin of the plateau, in the even divide between Coberly and Moses creeks, and in table bills southeast of Waterville, there are areas of considerable extent which are not now being eroded by streams. They present flattish surfaces, due to earlier low-level erosion, and are herein correlated as remnants of the plain once cut upon the basalt surface. From these remnants this plain is traced into the Cascade or Methow plain recognized by Russell.

Badger Mountain appears as a long, low hill when seen from the north from Waterville plateau. Although it rises 1,400 feet above the plateau, its slopes are so gentle, its surface so smooth, its length so extended, that it does not appear to be more than a hill. The summit is broad and flat, and long spurs with even slope extend not only northward but also southward several miles into the high valley of Rock Island Creek. Only when seen from the depths of the Columbia gorge or in relation thereto is Badger Mountain impressive, as toward the canyon it generally presents one or more mural escarpments of basalt crowning a confusion of landslide terraces, and it is conspicuous in height and mass.

The details of relief cut in its northern and southern slopes are more marked than those of the Waterville plateau, as might be expected from their steeper grade; but they are not accented by rocky walls, as are the similar features of Moses and Coberly creeks. Careful study of the two slopes of the mountain in riding across it discovered no conspicuous rock outcrops on the north or south. In the district of basalt flows, in which Badger Mountain lies, ontcrops are rare where the dip of the basalt sheets and the surface slope nearly or quite agree; the outcrops are, on the contrary, conspicuous and continuous, like terrace walls, where a gentle dip of the sheets is beveled by a steeper surface slope. It is inferred, thereforo, that the basalt sheets conform in a general way to the arehed surface of the mountain, as they do to the surface of the Waterville plateau and of the synclinal valley of Rock Island Creek.

When the physiographic features of the mountain are compared with those of the plateau they are found to be very similar if not identical. In the plateau there may be recognized flats of an old lowland and later slightly developed relief. On Badger Mountain the flats may be identified in surfaces of long unmodified spurs and in the level summit, while the later relief appears more decidedly developed, but of the same stage as that of the plateau. The mountain therefore appears to be a part of the plateau, raised to a greater elevation without interruption of the slope. In consequence of altitude and accented grade, the mass is undergoing more rapid corrasion than the adjacent plains of like rock, but the process of dissection has made 
very little progress. Hence we may infer comparative inefficiency of the process or recency of relative uplift, or both.

\section{TRIBUTARIES OF THE COLUMBIA.}

The traveler following the eastern bank of the Columbia crosses but a single stream, Coberly Creek, whereas along the western bank from Wenatchee to Chelan he encounters in 35 miles six streams, of which three are rivers. This distinction is not limited to the short stretch under consideration, it being true of the Columbia tbroughout central Washington. From Spokane River to Snake River, 275 miles, no tributary of noticeable size enters from the east, while seven large rivers come in from the west. On the one side is an arid plateau; on the other, well-watered mountain systems.

Wenatchee River, Lake Chelan, the independent streams between them, and their tributaries drain approximately 30,000 square miles of high, mountainous country, which receives for the most part very heavy precipitation. The volume of water which they contribute to the Columbia is accordingly large. The three dominant rivers are Wenatchee, Entiat, and Chelan. Their courses are practically parallel, and at first sight, as stated by Russell, ${ }^{a}$ appear to be simply consequent upon the surface slope of the uplifted Cascade Plain. Evidence will be given later to show that Chelan is a composite stream, made up of several parts united by piracy; and it is probable that Entiat also consists of parts of what were formerly distinct streams. The history of Wenatchee River is not made out in detail, but it has a wider branching system than the others, and may, like them, be a composite river. Reason will be shown later, however, for considering it an older river than Chelan, and one which has lost to the Chelan system an important part of its headwaters. The Yakima and Methow systems appear to be equivalent to the Wenatchee in age and general history, and these three may be classed with the Columbia as representing a drainage system from which the existing one is derived by adjustments.

The several valleys which join the Columbia from the west between Wenatchee and Chelan may now be appropriately considered.

WENATCHEE VALLEY.

Wenatchee Valley is developed on a mass of arkose sandstone lying between harder granite and gneiss. Whatever the antecedent conditions of drainage, adjustment to this soft mass and opening of a wide valley must result in time. The degree of adjustment attained and the extent of the valley appear to be such as to show that there has been adequate time. In one respect, however, the river exhibits an eccentric course. After flowing some miles southward in the sandstone area, it turns abruptly westward and crosses into the adjacent granite on the west. Russell ${ }^{b}$ 
describes the depth of the canyon which the river has cut in granite as 3,000 feet, and the length 6 miles. An interesting problem is thus presented, and several alternative hypotheses occur in explanation. First, there is the idea that the meandering river was superimposed upon sandstone and granite at a time when their surfaces came to a common peneplain. ${ }^{a}$ In this view the eccentricity is an original feature which adjustment has not yet modified. Second, the broad valley which exists in the sandstone may be looked upon as the original course of Wenatchee River, and the eccentricity of the present channel may be ascribed to diversion. A possible cause of diversion may be found in glaciation. As described by Russell, the Wenatchee glacier once filled the upper valley as far down as a point abreast of the present entrance of the river into the granite canyon. Under appropriate topographic conditions the ice might be competent to carry a stream flowing on its western margin over a divide into a small ravine adjacent, and thus the conditions for development of the present relations might be established. The fact that Upper Wenatchee River flows along the western side of its broad valley lends color to the hypothesis.

At present a low divide crosses the sandstone area south of the elbow which carries the Wenatchee into the granite. The divide is so low that it does not interrupt the view up the valley from Leavenworth, and its sky line falls in with the general elevation of neighboring hills of sandstone, while all such hilltops lie much below the granite and gneiss mountains on either hand. It is this view of a continuous valley which suggests the hypothesis of a formerly straight and now diverted course of Wenatchee River. The divide, nevertheless, requires explanation. Its elevation above that part of the valley upstream from it is a condition which could have resulted only from degradation of the upper valley, since the Wenatchee ceased to flow straight south across the divide. The depression of the upper valley may have occurred (a) through post-Glacial work of the diverted river; (b) during a glacial epoch through ice erosion by the Wenatchee glacier; (c) in interglacial time by degradation due to the diverted river, provided the stream was turned into the granite area during an carlier glacial epoch than that which is well known by its evident and widespread phenomena. Two epochs of glaciation are recorded in separate tills (the Admiralty and Vashon tills) in the Puget Sound Basin, ${ }^{b}$ and the glaciers were there confluent from the Cascades, yet in the area of glacial erosion records of one epoch only have been found. It is possible that general uplift and erosion were incidents of an interglacial time and that the earlier glacial sculpture and deposits have been largely obliterated. Detailed study of the profiles and gravels of Wenatchee Valley and Canyon may throw light on the problem of two glacial epochs. 


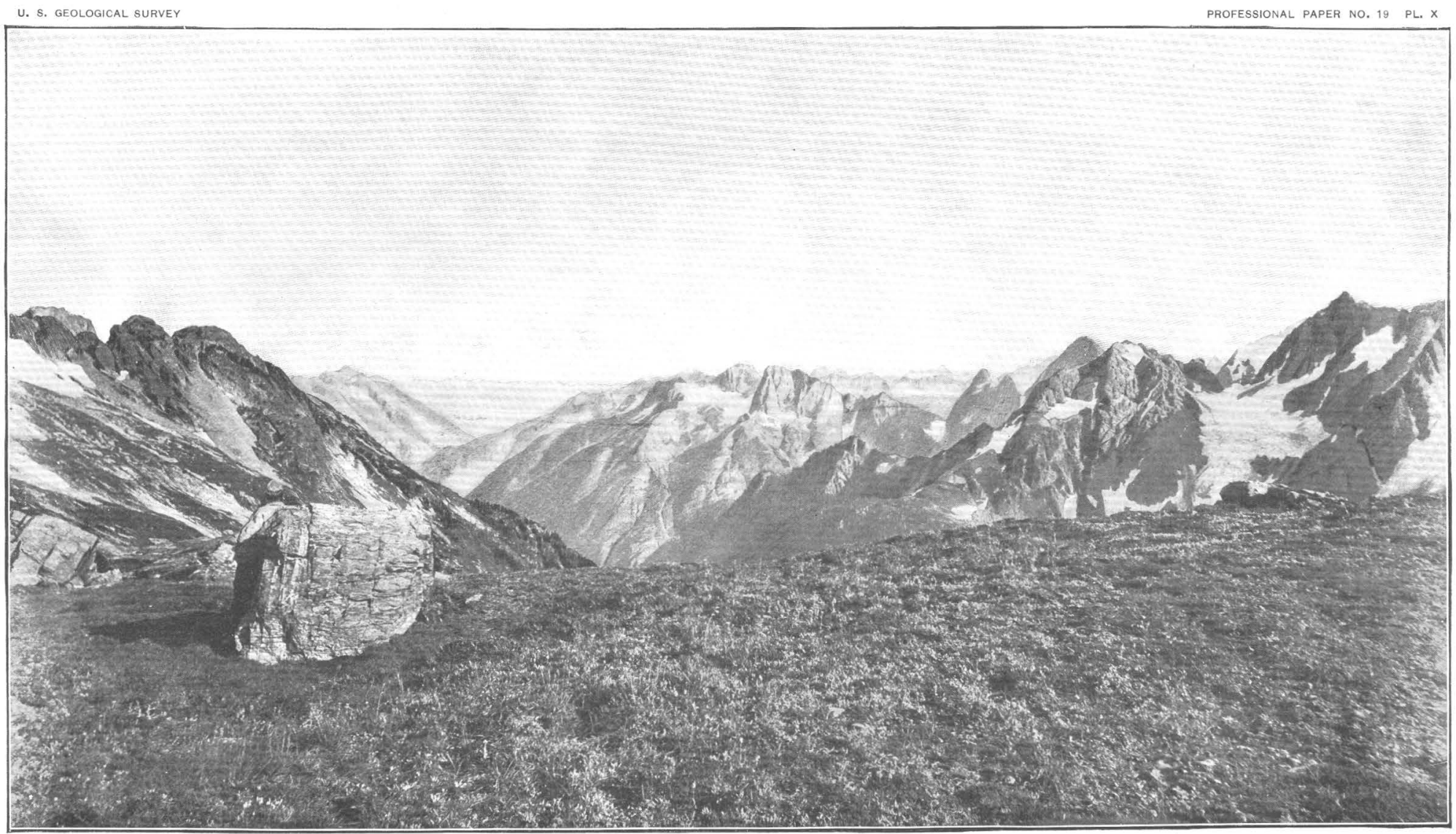

VIEW OF HIGH CASCADES FROM NEAR CASCADE PASS, SHOWING UNIFORMITY OF ALTITUDES, 
The effects of deformation which are described in the last sections of this paper may also be considered in this connection, and the area about Wenatchee Lake may be found to have been depressed or warped down relatively to the lower valley.

ENTIAT VALLEY

Entiat River is a small stream among its fellows. It lies between Wenatchee and Chelan ricers, and its drainage basin is surrounded by the basins of these streams, which join around its head and eut it off from the high glacier-bearing district of the Cascades. The stream is about 35 miles long and has a stranght course (S. $28^{\circ}$ F.) to within $3 \frac{1}{2}$ miles of its month, where it turns east to the Columbia. The valley is very symmetrical and is linited by the parallel Entiat and Chelan mountains.

The Entiat flows in a deep gorge, comparable in form with, but narrower than, that of the Columbia. Near its mouth the steep slopes are about 1,500 feet lingh, and on the south, up to 2,600 feet above the iver, the tributary ravines are sharply chiseled. North of the stream and 1,900 feet above it begin gentler slopes and broader features, which are connected with those that lie above the inner gorge of the Columbia. Up the Entiat, about the junction with Mud Creek, the canyon appears to be but 1,200 feet deep and near Stormy Creek not more than 1,000 feet. These differences are coordinate with the grade of the Entiat, which from Stormy Creek to the Columbia falls 950 feet, and thus sinks that much deeper below the practically lerel contour of the base of the outer gentle topographic forms.

Three miles above Stormy Creek the Entiat Valley bottom is half a mle wide and the slopes of the canyon are continuously steep for 3,500 feet up to the closely adjacent summits of Tyee Mountain and the Chelan Mountanns. This phase of the gorge is related in aspect and position to the section of Lake Chelan above Twentyfive Mile Creek. Each presents the appearance of a youthful canyon modified by glaciation, and their development will be further discusssd in stating the history of Lake Chelan.

The position of the Entiat Valley does not appear to be due to any zone of rocks weaker than others so far as the distribution of rock masses is known by examination of float in the river near its mouth and by traversing the Chelan Mountains. The area is one of gneisses and intrusives, probably related in intricate manner. The rocks of the erest of the Chelan Range are, indeed, dikes which are relatively hard, and the divide is determined by them; the Entiat Range may be similarly crested; but these dikes of hard materials are not confined to the summits They presumably occur irregularly within the Entiat Basin.

A simply fortutous condition might determine the position of a minor valley like that of the Entrat between two larger ones. but there are some reasons for 
believing that chance has not becn a dominant factor in this case. It will be shown that the Entiat Mountains are located on an uplift, which was there more pronounced than along adjacent lines. The trend of this uplift is northwest-southeast, and it now limits the Entrat drainage basin on the southwest. The Chelan Mountains are probably along a similar line of uplift. Thus the Entiat Basin apparently occupies the position of a depression between two uplufts, possibly a downwarp valley.

The stream is, however, older than the most recent carth movements which bave affected its present course. The uplift of the region in general, and of the BadgerEntiat Range in particular, ocenrred in two distinct episodes, and the first limited the Entiat Valley. The river appears then to have flowed straight to the Columbia. Its old channel is marked by the gap in the spuı southwest of its present mouth, the gap which is shown on the topog raphic map at the contour of 2,600 feet, and which is 1,100 feet below the hilltop that rises northeast of it. The interpretation is that the stream was checked by the later movement on the Badger-Entiat axis, and was diverted to a new course, its present easterly one. It has since then cut its inner canyon down 2,000 feet below the old one.

NAVARRE COULEE AND KNAPP COULEE

Navarre and Knapp coulees are unlike ordinary valleys in several respects. First, they carry no running water, except that from a spring which in each flows out near the level of the Columbia, at the foot of a gravel terrace. Second, the rivulets that now flow from beneath the gravel fillng and which gather from gulches tributary to the main coulee are disproportionately small when compared to the valleys they occupy. Third, the canyons which constitute their present upper sections continue beyond the divide and extend into the Chelan Basin. Fourth, they have wide, Hat fioors of gravel, the one 400 , the other 600 feet above the Columbra. This gravel filling appears as a conspicuous terrace when viewed from the castern bank of the Columbia. Fifth, the wash from the adjacent hills is so copious that alluvial cones are built clear across the flat-bottomed coulee, and thus sections of it are converted into hollows, which occasionly hold water and accumulate sediment.

In cross section the two coulees are miniatures of the Columbia gorge. Each exhibits a narrow valley or canyon within a wider valley and thus records eplsodes of development which are directly related to those of the great river. Like the Columbia, Navarre stream and Knapp stream had their beginnings back in the time of the ancient plain whose remnants barely survive in neighboring helghts. Navarre was always much larger than Knapp, and its features are more conspicuously developed.

From the Columbia the ascent to Navarre Coulee is by a sharp $\vee$ gulch, beyond which one rides out upon the surface of the gravelly tlat 400 feet above the river 


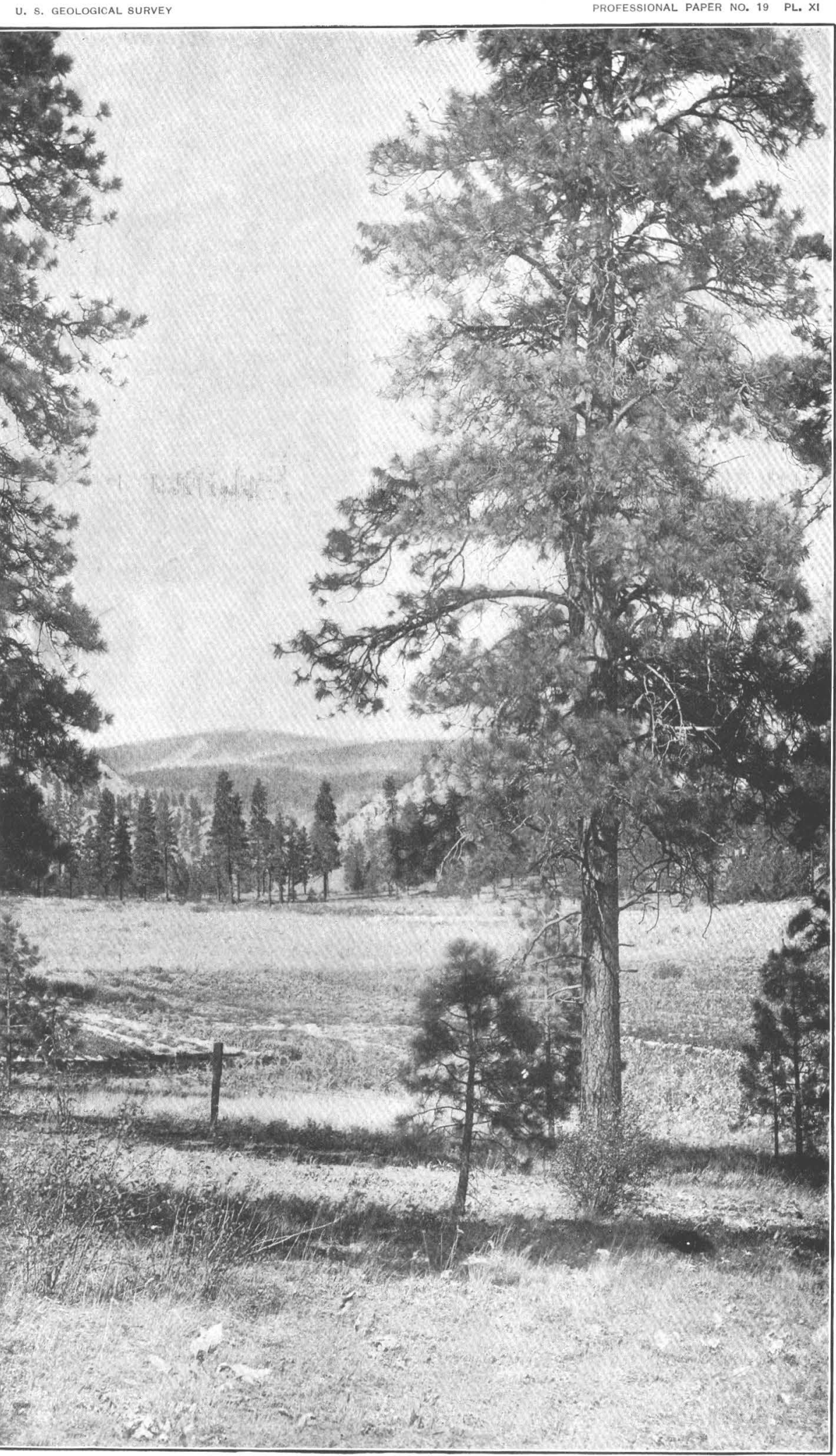

VIEW IN NAVARRE COULEE. 
(see Pl. XI), and for 5 miles may follow the level bottom. One then enters a narrower canyon, marked on the west side by a conspicuous vertical wall of granite 800 feet high, and in three-fourths of a mile passes through this gate into a pretty glade lying level between wooded slopes. The head of this glade is an amphitheater, little more than 200 yards in diameter and steeply hemmed in. It is silent now save for the sighing of the pines, but at its farthest point is the vacant site of a cascade, whose voice once resounded from the surrounding hills. 'The fall was about 150 feet and the volume of water was large. The stream was a river flowing from the Chelan glacier, and by this pass the great mass of gravel which fills the lower canyon entered Navarre Coulee. At the end of the latest glacial episode the ice sank within the Chelan Basin and the river found a lower eastern course. The cascade, however, is only the latest incident in the bistory of the valley. Before the ice time Navarre stream had cut the inner canyon and before that the outer valley.

Above the cascade's vacant channel, as one rides out upon a gravel terrace from which the slope descends 600 feet to Lake Chelan, the emphasis of the environment is upon the recent glacial condition; but reverting to the earlier history one finds no apparent source of the older stream. The valley is cut clear through the divide and ends in the air high above any streams which might once have been its headwaters.

Knapp Coulee closely resembles Navarre, but on a smaller and less emphatic seale. Near its southern end and western side bare rocks rise boldly in the face of the gravel terrace below the channel of the latest glacial stream and formed the sill over which the cascade dashed. Northward and 500 to 600 feet above the Columbia the surface of the gravel terrace extends 2 miles to a narrower section, which corresponds to the conspicuous canyon of Navarre, and by this pass the open slope above Lake Chelan is reached. Again the valley is cut through the divide and at least 400 feet below it, but the headwaters of the stream which accomplished the task have been so diverted to lower channels that they can no longer flow through the pass; indeed, they can no longer be positively identified, except that they must now be tributary to Lake Chelan.

The history of these coulees is thus seen to comprise in order (1) an early stage of valley development at a surface now above the 2,000-foot contour; (2) a phase of canyon cutting, which was sharply accentuated in a space just south of the Chelan Basin; (3) the diversion of the headwaters; (4) the reoccupation of the channels by glacial streams, which, being heavily overloaded, filled them with gravel; (5) their present condition, in which they are being aggraded by wash from the steep side slopes, and reexcavation has begun in gullies facing the Columbia.

These incidents of individual history, especially the accented canyons and diversion of headwaters, fit in with other evidences in the interpretation of the character and distribution of deformation of the region. 
LAKE CHELAN.

Lake Chelan is a slender body of water 65 miles long, whose southeastern end lies open to the sky between the grass-grown hills of the outer Columbia Valley, while its northwestern lies in shadow between precipitous mountains in the heart of the Cascade Range. There are sandy shallows near its outlet, but beneath the cliffs of its upper course the water is profoundly deep.

In brief technical phrase, the lake basin is a canyon modified, deepened, and dammed by glaciation. The canyon, is that of the Stebekin-Chelan River, which rises in latitude $48^{\circ} 30^{\prime}$ in glaciers of the Cascade Range at altitudes of 5,000 to 8,000 feet. The headwaters descend very abruptly, 1,000 to 1,800 feet in the first mile below the glaciers, and combine in a $U$-shaped valley of gentler grade, the fall being 2,500 feet in 23 miles. This section is cut in rock bottom. For 12 miles farther downstream the valley is floored with bowlders, coarse gravel, and sand, and the slope is but 20 feet to the mile, ending in the delta which the stream is building into Lake Chelan.

The gravel-filled section of the valley is no doubt deeply eut in the solid rock, since but a short distance beyond the front of the delta the lake is more than 500 feet deep. For a distance of 35 miles the depth varies from 1,000 to 1,400 feet, 1,419 being the maximum as yet sounded. As the water surface is but 1,079 feet above sea, the bottom of the lake is for a short stretch 300 feet below sea level, and an interesting question is raised as to how so deep a basin originated. Fifteen miles from its outlet the lake begins to shallow, and in its lower reach does not exceed 200 feet in depth.

The water is retained at its present level by a dam of sand and gravel, which in the section exposed by Chelan River is seen to consist of several successive members, i. e., soil, coarse stream gravel, till, very coarse gravel in pockets or channels, and cross stratified sands. The base of the drift is not exposed. This drift dam fills the preglacial valley by which the Stehekin-Chelan River once reached the Columbia, and the present outlet turns from the drift into the gneiss and granite south of it, and has there cut a deep rock gorge.

The topographic environment of Lake Chelan presents several distinct phases. (See Pls. I and XIII.) About the eastern end the general aspect is that of a wide, open valley bounded by hills 1,500 to 2,500 feet high. The slopes are marked by long, low spurs, whose profiles rise moderately, but with increasing angle upward to the summits. Slight hollows between them have consistent grades. The surface is that of mature topography characterized by profiles which are concave upward, but on traversing the hilltops one notes in their flattish and rounded forms that the stage of maturity is not everywhere completely developed, else the ridge crests would be sharp, and sympathetic with the active corrasion of the slopes. The earlier phase is not, however, distinctly traceable in these summits. 
Upon this mature surface are cut and built certain younger features. Where the major spurs sweep downward to the level that once was the valley floor and become gentle in slope, they end abruptly in steep or precipitous facets which break directly down to the lake shore and are about 400 feet high. These bluffs might readily be attributed to ice erosion, in view of the conspicuous evidences of glaciation in the Chelan Basin, but they are traced and correlated with the steeps which wall the inner gorge of the Columbia below the limit of any glacier, and they therefore are similar elements of the Stehekin-Chelan canyon which was cut within the mature topography of an earlier date.

Terraces which fill the hollows and occasionally skirt the slopes for some distance occur at various levels up to 1,100 feet above the lake. Their topographic position, relations among themselves, and constitution show that they formed in lakelets confined on the hillside by spurs and on the now open side by the glacier which occupied the Chelan Basin. A full discussion of them belongs to the glacial history of the region.

In the view from Chelan Butte northwestward, the lower section of Lake Chelan is seen for a distance of about 15 miles to occupy the wide basin just described. Its trend in this stretch is north by west 8 miles, and thence due north 7 miles. Along the western side of the latter reach runs a bold ridge, whose even crest is 3,600 to 4,200 feet above the lake and whose eastern face descends precipitously nearly to the water. A marked feature of its scarp is a deeply stained surface, freshly exposed, which is locally known as Red Slide. The lake trends westward around the northern end of Red Slide ridge and disappears from view among lofty mountains. The Methow Range lies north, the Chelan Range south, both rising to more than 7,000 feet above sea within 5 or 6 miles of the lake, and both sending out long, high spurs which maintain altitudes of 6,000 feet above sea to within 2 miles or less of the lake. From these spurs descend very steep slopes, scored by little ravines and worn by glacial action.

Sunk deep among the mountain heights, the fiord-like lake extends 32 miles. The grandeur of the scenery readily lends itself to superlative description, but exact statement must be moderate. The walls of the canyon are sloping, not precipitous. Bare and gray and desolate, the mountain sides and cloud-draped peaks are very impressive, but though their height be 6,000 feet above the lake they nowhere tower in precipices like Yosemite walls. The maximum inclination is usually near the water surface, and for a hundred feet or so may locally approach 60 degrees. Generally it is less than 40 degrees. And from this steepest facet the profiles rise in a curve which is convex upward, and pass into the nearly level spurs of the adjacent ranges. The narrowest and boldest section of the canyon is just above Safety 
Harbor Creek. It is called the Narrows and is shown in the view Pl. XIII, and in profile in fig. 5 of $\mathrm{Pl}$. XIX.

The physiographic features of the fiord lake are readily correlated with those of the Columbia River gorge. The steeps of the latter are not only homologous with the walls of the former, but they are mutually traceable one into the other through Navarre Coulee, Knapp Coulee, and the Lower Chelan Basin. That they are due to a common activity-the familiar corrading action of a stream-is apparent. They differ, however, in certain aspects. The gorge of the Columbia exhihits acute pinnacled rock ledges cropping through slopes of soil and loose rock. The canyon of Lake Chelan presents massive rounded bosses of rock, cleaned and worn down by. a mighty scouring action. This is the work of ice which, as a glacier, flowed through the fiord, driven by the accumulations in the tributary valleys of the Cascade Range.

The diverse aspects of the Chelan Basin invite discussion. Its lower valley section and its upper fiord-like extent are of different topographic stages, the one being mature, the other young. Their diversity may be explained as the result of either one of two conditions or of their combination. The lake basin below Twentyfive Mile Creek may be cut in softer rocks than the part above that stream, and its more advanced topographic development may be due only to a consequently greater rate of erosion. Or the section below Twentyfive Mile may actually date farther back in time than the upper portion, and may have attained its present stage through longer exposure only. But in the view now held by the writer both of these conditions have been effective.

As to the rocks in large masses they may be considered in two classes. The sufter ones are gneiss and schist; the harder are jointed intrusive rocks. Granite occurring as dikes outcrops in bold ledges in Chelan Butte and elsewhere, and is one occasion of the high divide south of eastern Chelan Basin. Rhyolite-porphyry and graniteporphyry dikes stand out ruggedly as the crest of the Chelan Range, and similar rocks occur extensively in the Methow Range, at least about the head of Safety Harbor Creek. On the other hand, the rocks seen north of the eastern part of Lake Chelan are micaceous and schistose. In so far as these differences coincide with heights and hollows, we may attribute a certain effect to them, and the most conspicuous instance of such coincidence is found about Lake Chelan below Twentyfive Mile. But on the whole the region is characterized by indifterence of topographic phase to rock structure, and the distinctions described are not adequate in themselves to explain the great features of Lake Chelan.

A number of facts go to show that the Stehekin-Chelan canyon is a composite one, and that the development began at the east and extended westward. In that case the eastern section dates farther back, and its advanced topographie aspects 


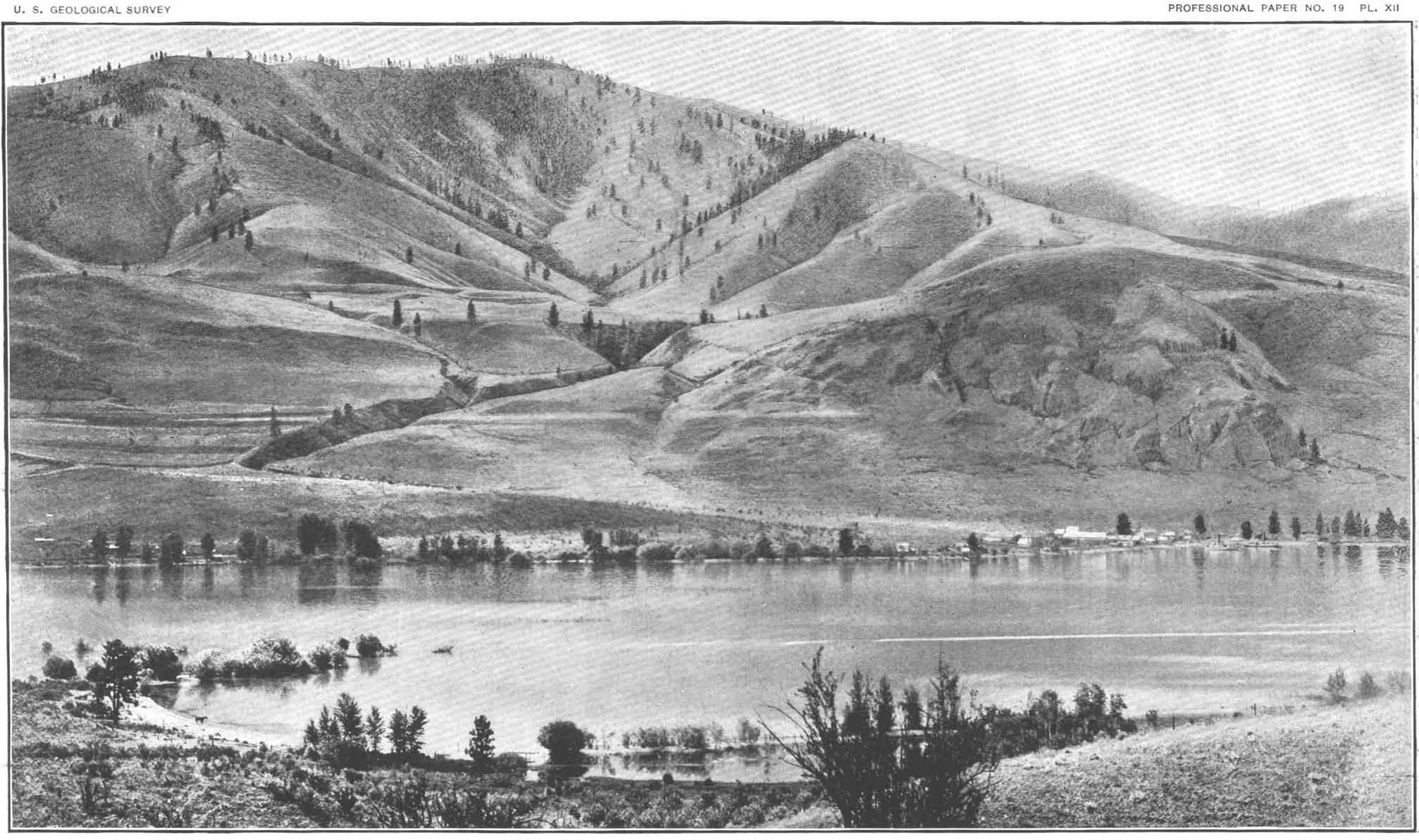

CHELAN BUTTE FROM NORTH SHORE OF LAKE CHELAN. 
may thus be explained as not only more aged in appearance, but actually older. If the valleys of Navarre and Knapp have been properly interpreted as beheaded, Chelan Canyon, below Twentyfive Mile, carries their headwaters. The drainage once consisted of Chelan Brook, a little stream which entered the Columbia at the old outlet of the Chelan Basin half a mile above its present mouth, and which headed east of Knapp Coulee; of Knapp Creek which drained certain slopes north of the present Lake Chelan; and of Navarre stream, which was composed of First Creek, Twentyfive Mile, and the brooks that enter Lake Chelan east of Falls Creek. It is doubtful whether Falls Creek then existed, and a divide is thought to have extended from Navarre peaks of the Methow Mountains uninterruptedly across to the Chelan Range. According to hypothesis, little Chelan beheaded Knapp, greater Chelan captured upper Navarre, and the valley below Twentyfive Mile was established in its present course.

This piracy is attributable in part to adjustments of drainage to hard and soft rocks. As already stated, both Navarre and Knapp coulees exhibit sharply accented canyons near their northern ends. These are in hard granite. Columbia River, if it encountered this same granite axis farther east, would reduce the obstacle much more rapidly than the smaller streams could, and thus little Chelan Brook, flowing on softer gneiss with a low outlet might gain sufficient advantage to divert its stronger neighbors. - It is believed that this condition existed and was infuential in effecting the readjustment, but its sufficiency is doubted unless it was aided by other circumstances.

Deformation is believed to bave played an important if not a major part in the diversion of upper Navarre and Knapp to Chelan. As will appear in the synthetic study of the Methow plain, its remnants are recognized south of the ridge which connects Baldy Mountain and Chelan Butte and on the western part, but not on its eastern extension. (See Pl. XVII.) The area of the ridge appears to have suffered greater degradation, which is attributed to that greater elevation of which there is evidence in the position of the Methow plain. This upwarp stretched across the courses of Navarre and Knapp streams and ponding their upper courses, made them an easier prey to little Chelan. The accented canyons which they now exhibit as the upper sections of the coulees are interpreted as evidence of the efforts made by the streams to maintain themselves before capture.

The preceding interpretation suffices only for the Lower Chelan region. The extension of Chelan drainage above Twentyfive Mile and to the Stehekin is still to be explained, and that explanation depends chiefly upon the slope, which connected the upraised surface of the Methow plain at an altitude of 8,500 feet or more with the level of that same topographic surface east of the Columbia at 3,500 feet. This slope is shown in fig. 4, Pl. XIX, east of Navarre Peaks, but it is there probably 
gentler than it was toward the basin of lower Lake Chelan at the place where Chelan drainage beaded against it. There can be no question but that the development of that slope caused vigorous growth of the head branches of streams rising on it, and that capture and diversion of any river less favorably situated must result. That there was such a river appears to follow from the recognition of an old valley which now lies at a great elevation and is completely dissected. In describing this feature it will be convenient to name it, and it will be called Russell River. ${ }^{a}$

The valley of Russell River was first recognized in the summer of 1899 in a view east and northeast across the Entiat and Chelan mountains. On the southeast the Mount Stuart group formed the right wing, and on the northwest the high summits of the Cascades were the left wing. In the far distance on the horizon lay the basalt plateau of central Washington. According to expectation, the Chelan and Entiat mountains, extending from the high Cascades on the west to the basalt plateau, should descend in a general slope without marked depression along the mid-sections, or decided elevation in the eastern ends. But such depression and elevations were striking features of the view. Stormy (7,219 feet), Baldy (6,432 feet), Tyee (6,688 feet), and heights in the eastern Entiat mountains not yet mapped stand higher than those portions of the ranges between them and the Cascades. The profiles of the lower mid-sections of the ranges are peculiarly flat and suggested cross sections of a shallow valley. The heights east of the mid-sections are traversed by the deep canyons of Eritiat River and Chelan, such canyons as should be formed by streams attacking an elevated bench and retrogressively cutting into it. The slope of the supposed bench forms the eastern side of the Cascade mass and is a necessary feature connecting the mountain block with the lower surfaces on the east. And a stream flowing on the bench and parallel to its face in the general position of a valley corresponding with the lower mid-sections of the range would be peculiarly liable to capture.

When in 1899 this hypothesis of the former existence and complete diversion of Russell River was framed, equal consideration was given to another explanation. It was that the depression along the mid-sections of the ranges was due to a zone of weak rocks, which had wasted faster and yielded lower divides between the attacking streams. In 1900 these hypotheses were tested so far as practicable. The depression was clearly recognized from various points of view on the Chelan and Methow mountains, and it was visited at the only place accessible to the route followed. This place is in the southwest corner of the Methow quadrangle (see Pl. XVII), about the head of Lake Creek. The divide between Lake Crcek and Lake Chelan is 5,900 to 6,000 feet above sea, and the heights on the east rise above 6,700 with points over 7,000 , while those on the west reach 8,500 feet at a considerable distance. The low

a In honor of Prof. I. C. Russell, who first published an aceount of the Methow plain, on which the river flowed 


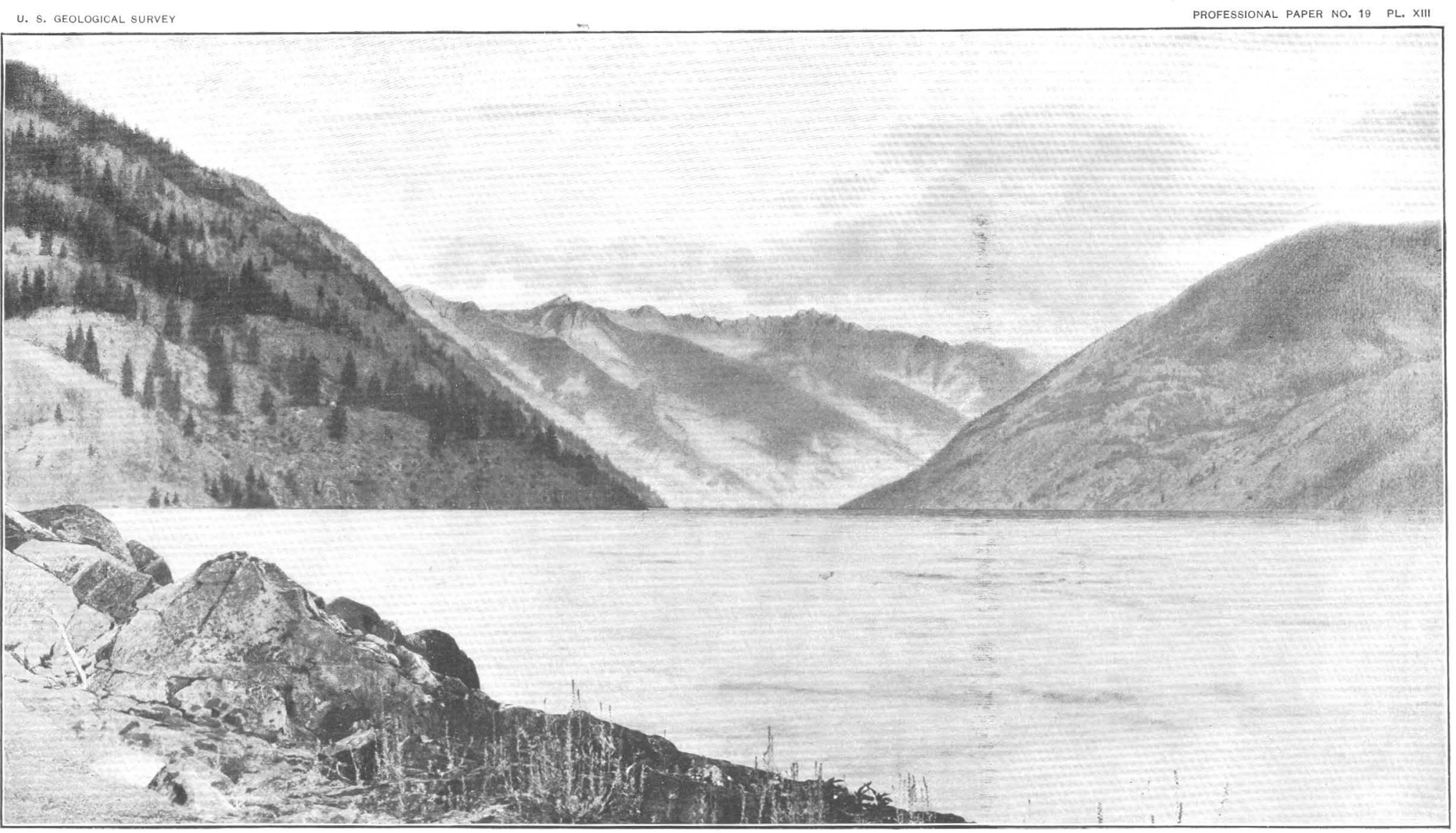

NARROWS OF LAKE CHELAN. 
pass is a mile and three-quarters wide between the points of the 6,000 -foot contour. The ridge was examined for the presence of a weak zone of rocks, but it was found to consist of gneiss cut by granite in essentially the same relations and of the same general character as the masses of the heights on either side. Specially active work of the streams opposed to each other across the divide is not evident, the crest being broad and deeply covered with soil. The further thought that the depression was due to locally energetic agencies of present streams or possibly of past glaciers, was therefore not sustained.

On the other hand, positive evidence of Russell River, such as river 'gravel, was not found, and indeed could hardly be expected to have survived. The ancient stream thus remains in a measure hypothetical rather than known, but its supposed course may be sketched as follows: The headwaters of Russell River are now known as the Stehekin and are diverted to the Chelan system, the diversion having occurred at a point now about 10 miles southwest of Navarre Peaks (Pls. VIII and XVIII), and 6,100 to 6,300 feet above sea; that is in the air 5,000 feet or more above Lake Chelan. Thence the course of Russell River was across the divide at the head of Lake Creek, the valley floor lying probably above the lowest sections of the ridge as it is now sculptured. Lake Creek may be a surviving remnant of the old stream, representing a beheaded section which was cut off also from its lower course by the Entiat. Between Entiat and Wenatchee rivers the valley of Russell River is marked in the heights, and the course was probably southwesterly. Finally Russell River joined the Wenatchee, of which it was the northern and possibly the principal branch.

Reverting now to the development of the Chelan system, we bave to consider what may have been the conditions if Russell River did not exist. In this case the writer has little to present that is satisfactory. It may be assumed that Chelan and Stehekin constitute a consequent stream, which has flowed in its present course without any such complex adjustments as have been discussed; but in that case the beheaded condition of Navarre and Knapp coulees remains an unsolved and apparently insolvable problem. If again it be suggested that Navarre stream formerly included not only Trentyfive Mile but also all the upper Chelan-Stehekin drainage, the valley of Navarre is disproportionately small, and the diversion of so large a river to the present outlet appears altogether improbable.

The youthful aspect of Chelan Canyon above Twentyfive Mile remains a fact, whatever the early history of the drainage system, and is due to and evidence of recent uplift of the mass in which it is sculptured. Its significance in relation to deformation will be further considered in discussing that subject. 
ENTIAT MOUNTAINS.

To see the Entiat Mountains against the sky and in their relation to the Columbia gorge and Badger Mountain, one should ascend the spur between Navarre and Knapp coulees to an altitude of 3,100 feet. Thence Badger Mountain presents an unbroken even-topped height which is taken up by the Entiat Mountains and carried westward for 2 miles till it rises into conical poaks 800 feet higher. (See profile 7 , Pl. XIX.) The otherwise uniform sweep is broken by the great valley of the Columbia, which clearly exhibits its inner gorge and outer slopes. Restoring what the river has cut away, the topographic continuity of Badger and Entiat is apparent, and they are also geologically a unit, since the basalt and gneisses occur in similar relations in both.

The continuity of structure and profile of the mountains which the Columbia divides shows that they are of one mass that moved as a unit in the uplift of the region. Similar reasoning and conclusion apply to Waterville plateau and the mesa north of Entiat River. They also, though divided, are of one mass, but their surfaces lie 1,000 to 2,000 feet lower than the mountains. The river's trench is deeply cut in both masses, but if we filled it to the brink between the plateau and the mesa, the stream could not flow across the higher mountains before it. It is clear that when the river adopted its course the mountains were not higher than the plateau, but that since that time the Badger-Entiat mass has been raised higher than the region north of it. As has already been pointed out, this uplift sufficed to cause the diversion of the lower part of Entiat River, but it did not rise with sufficient rapidity to turn the great master stream, the Columbia.

The broad flat at the eastern end of the Entiat Range, 4,500 to 4,900 feet above sea, corresponds in extent with a basalt remnant. The dip of the basalt is not less than 3 degrees and probably nearer 5 degrees to the north. The slope of the surface is about $1 \frac{1}{2}$ degrees in the same direction. The dip and slope therefore appear to diverge 150 feet or more to the mile. If we assume that at any time the surface was level, the basalt then dipped $1 \frac{1}{2}$ or more degrees, and the level crossed the basalt beds at a slight angle. It is more probable that the surface declined slightly down the course of the Columbia and was cut across the nearly level basalt. Both have been tilted in the uplift of the Entiat Range.

Though small, the angle at which the flat surface and the basalt bedding diverge is important, since the surface is thereby identified as one of erosion in contradistinction to one of structure. The evidence is slight and by itself insufficient to establish a conclusion, but it is sustained by the fact that in this region similar flats are cut across structurally indifferent gneiss and granite, and it is corroborated in the Yakima district by the definite observations of G. O. Smith, with which it is in line. 


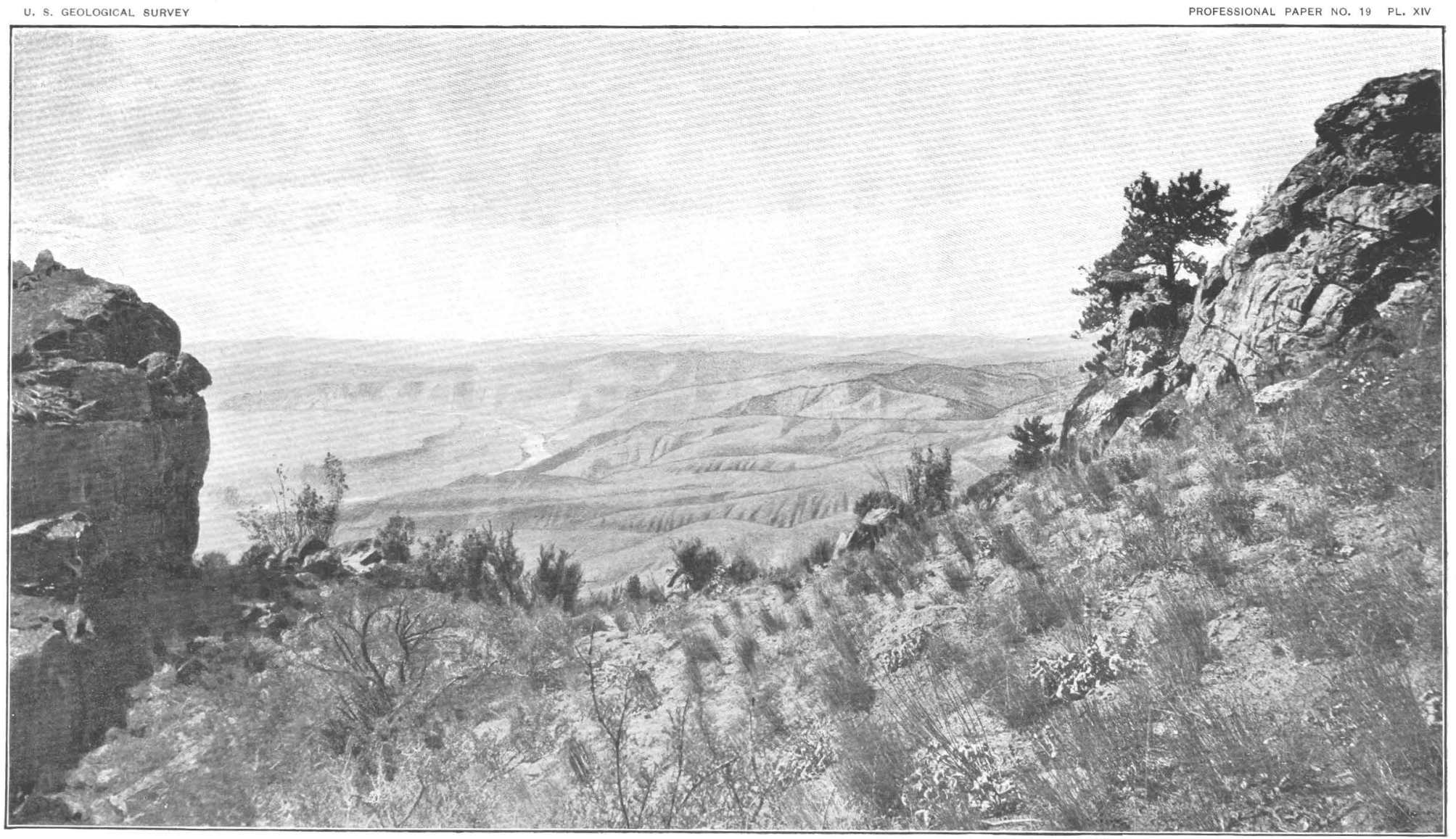

VIEW FROM CHELAN BUTTE, LOOKING SOUTHWEST DOWN THE COLUMBIA VALLEY. 
CHELAN MOUNTAINS.

From Columbia River at Navarre Coulee an Indian trail leads to Stormy Mountain, the highest point of the Chelan Range, and following the crest for some miles in a northwesterly direction crosses the Entiat Valley and the Wenatchee Mountains toward Leavenworth. Like most Indian routes in this region, it was chosen from among the many possible ones because it presented little difficulty to the passage of horses, the ridges followed being of gentle rise. To this fact of topographic form and to exceptions to it, attention is now called.

After a sharp scramble of 1,200 to 1,600 feet it is a surprise to ride out upon nearly level or broadly rounded surfaces which are deeply mantled with soil. Yellow pines (Pinus ponderosa) grow vigorously, but widely spaced, as is their habit; the surface is scantily covered with grass, and groups of shrubs stand here and there. A few hundred feet to right and left this surface rounds off into steep slopes that descend to adjacent hollows. Follow a lateral spur of the ridge and you come to a cliff, the margin of a larger ravine. Pursue your course northward along the ridge and you ascend easily, though with occasional slight descent, to about 4,000 feet above sea. Gradually the ascent becomes steeper to the top of a ridge at 5,000 feet, and following this two miles to the eastern side of Baldy Mountain you strike a moderate slope of limited extent at about 5,500 feet above sea. Above this Baldy presents a serrate ridge whose highest tooth attains 6,432 feet above sea. The height, the ragged angular forms, and bare talus all mark the hardness of the rocks, risyolitic porphyry and granite, which occur in a system of large dikes traversing hornblende-gneiss. Stormy Mountain (7,219 feet), the spur (7,142 feet) 8 miles northwest of Baldy, and much of the intervening crest are sustained by similar dikes and present the same acute topographic forms, but adjacent to them, at elevations above 6,000 feet, there are gently rounded flattish surfaces, which are physiographically not in sympathy with the active work of frost on the peaks above or the energetic corrasion progressing in the ravines near by. These flats are of small extent, but of definite character. The most apparent one lies between 'Twentyfive Mile and Lake creeks, where the divide trends north, leaving the dike system of rbyolitic porphyry that runs out in the sharp peak at 7,142 feet. For convenience, it may be called Fourmile Ridge. The prevailing rocks of Fourmile Ridge are granite and gneiss, which afford no structural occasion for the flattish surface. For a distance of 4 miles the summit bas a general elevation above 6,600 and below 6,800 feet, declining gently northward. It is slightly notched at several points, and even where it widens out it is rounded, not level. But lying as it does between steep and even precipitous slopes which descend a thousand feet into the adjacent depths, its grassy, soil-corered surface is a striking remnant of an earlier physiographic 14493-No. $19-03-5$ 
condition. It is a derivative from a pla1n, and although modified it has not lost 1 ts significant aspeet, a long and practically continuous uniform slope. (See profile 5, Pl. XIX.)

Had the rider, ascending from the Columbia along the old Indian trall, turned southwest on the level ahove the 3,000-foot contour, he might have followed the divide between the Columbia and the Entiat, over the broad hill having an altitude of 3,757 feet, and out onto the bit of platean or mesa which overlooks the junction of the two livers. As may be seen from the topographic map, the accents of the ridge are slight, but the ravines carved in its sides are acute. The surface at an altitude of about 3,757 feet, its northeastern and southwestern spurs, and the mesa southeast of Strummel Canyon are peculiarly broad and simple forms as compared with therr environment. The mesa exhlbits occasional hasalt scarps and is a corner of the Waterville plateau isolated by the Columbia Gorge. Through its structural and physiographic characters it is an important link between the great plateau and the Chelan Mountains. Approaching the mesa in form, but unlike it in rock structure, the hill having an altitude of 3,757 feet contmues the same topographic phase, and its spurs extend the type on the one side to the Entiat Gorge, on the other to Navarre Coulee.

Considered as a whole, these features are clearly distinguishable from the steeps which are now subject to energetic corrasion by brooks and rivulets Considered in detail, two less clearly distinct phases may be recognized among these broader features Discriminating by form we may find surfaces which approach a plain and those which are marked by moderate relief; judging by relative elevation, we shall discover the plainer surfaces above the more clearly sculptured ones, but without definite boundaries between them. Carrying the comparisons over wider areas the flats are found at different heights, but always in the same physiographic relations.

Thus, physiographically, the mesa, the spurs of the hill with an altitude of 3,757 feet, and Fourmile Ridge belong to one and the same stage. The crests of the hill which has an altitude of 3,757 feet, of Baldy, of Stormy, and of the hill which has an altitude of 7,142 feet, are older monadnocks, whereas the long spur's of the range fall into the class of later features, and the canyons of all magnitudes into that of the latest.

\section{METHOW MOUNTAINS.}

The Methow Mountains lie between Lake Chelan on the southwest and Twisp and Methow rivers on the northeast. Only their southeastern portion, up to Stal Peak, is included in the accompanying map (Pl. XVIII) and in the profile (Pl. XIX). A portion of it, known as Sawtooth Ridge, extends with serrate and glacier-bearing peaks into the heart of the high Cascades. 


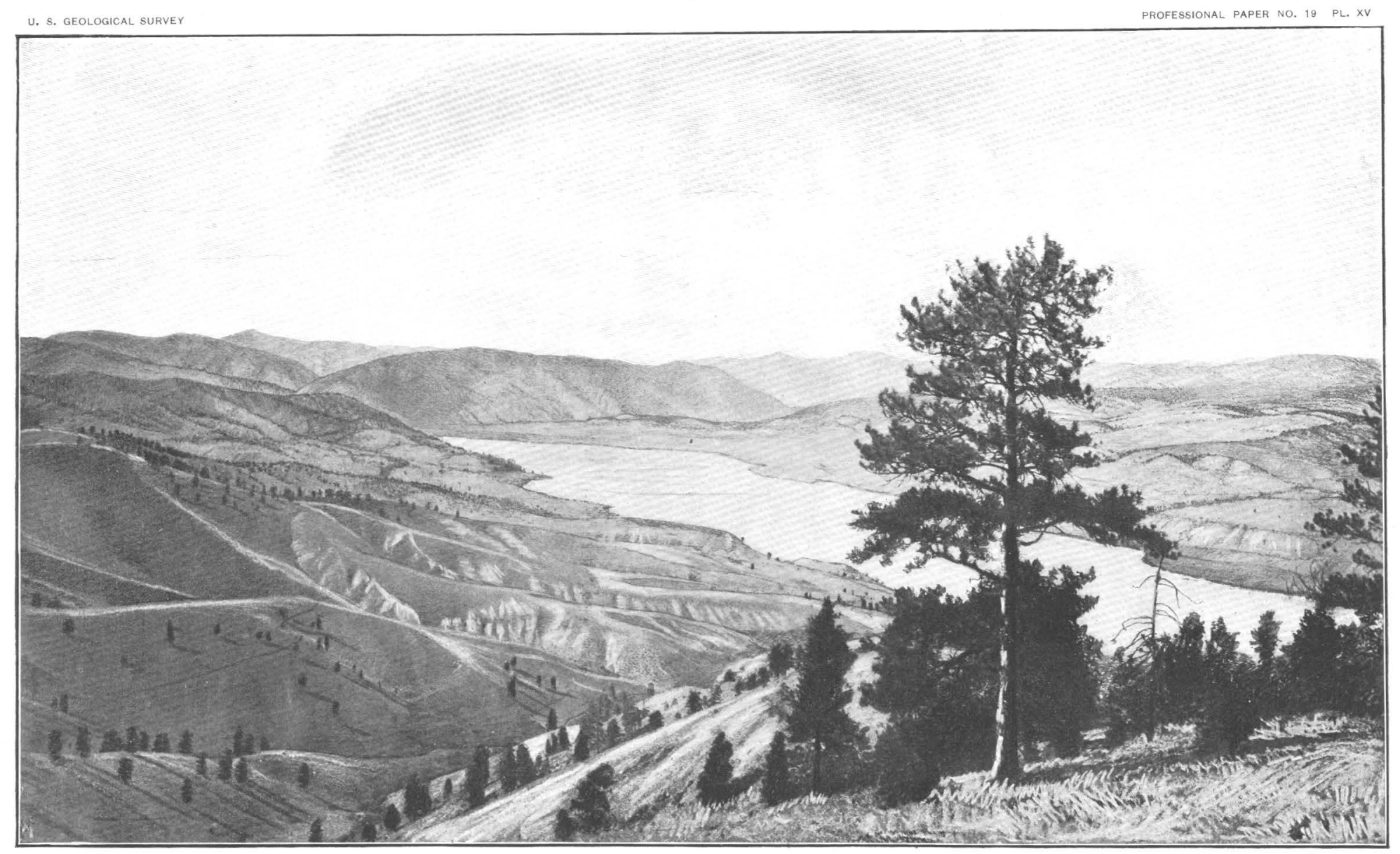

VIEW FROM CHELAN BUTTE, LOOKING NORTHWEST OVER LOWER LAKE CHELAN TO STORMY MOUNTAIN AND NAVARRE PEAKS. 
At their eastern end the Methow Mountains are no higher than the neighboring plateau east of the Columbia. Like the Entiat and Chelan mountains they are structurally continuous with the plateau, from which they are separated only by the canyon which the river has cut. Looking northward from Chelan Butte or the margin of the plateau above Chelan Ferry, the sky line of the plateau is continuous with that of the Methow Mountains at an altitude of about 3,400 feet. Rising westward with moderate grade the peaks of Navarre are reached, 7,800 to 8,200 feet above sea, and thence northwestward for many miles the summits are of remarkably uniform altitude

As a mountain mass between Lake Chelan and the parallel valleys northwest of it, the Methow Mountains are 12 to 15 miles across from southwest to northeast. They have a very definite watershed from which all streams flow by the shortest routes to Chelan, Twisp, or Methow rivers. West of a line drawn north and south about 3 miles east of Navarre Peaks the crest is narrow and often ragged, but high spurs extend out on either side to distances of 3 or 4 miles, mantaining in their heights the general altitude of the watershed. Navarre Peaks are the southeastern representatives of a large number of points which closely approach or slightly exceed 8,000 feet in elevation, and which are linked together by high ridges branching from and on a general level with the central divide. These peaks and spurs are clearly derivatives from a plateau.

The eastern part of the summit exhibits some broad areas, and from them the spurs decline gradually, especially toward the southwest. As compared with the deep canyons cut in them, these surfaces belong to an earlier stage of topographic development. They are residuals which distinguish the district east of an ideal line from the region of acutely mature topography west of it. The distribution of these residuals and of the drainage lines flowing southwest and northeast suggests that the surface between the Methow and the Chelan east of Navarre Peaks would, if restored, form an arch pitching southeast and merging in that direction into the basalt plateau. Traced westward this arch flattens out in a level above the summits. of the higher part of the range.

In topographic forms and drainage the Methow Mountains present most interesting problems which involve the discussion of earlier topographic phases, deformation, stream adjustment, and glaciation. But the writer's opportunities for observation have not been sufficient to solve them. 


\section{SYNTHETIC DISCUSSION}

GENERAI STATEMENT.

In the preceding pages the separate features of the region have been described as they now are, and their interpretation in terms of topographic development has been suggested. In what follows it is proposed to discuss each stage of that development from the earliest recognized up to the latest glacial epoch. The glacial phenomena are very conspicuous and have been noted from the terraces of the Columbia to the lingering glaciers of the Cascades, but their record is one which is more complex than can be read without special studies which are yet to be made by an experienced glacialist. That chapter is therefore not included in this discussion.

Enough has been said in the descriptions to indicate that several stages of topographic development have been recognized. They are clearly evident in such a profile as No. 1, Pl. XIX, from the Entiat Mountains across Columbia Canyon to Badger Mountain. Beginning with the highest, the peaks (5,700 to 5,800 feet) and the flat adjacent to them are considered to be representatives of the oldest stage of which definte evidence remains. They are correlated with Badger Mountan, the Waterville plateau, surfaces in the Chelan and possibly the Methow Mountains, and the level from which the high Cascades aro sculptured. This oldest stage is therefore that of the Cascade plateau, as named by Russell, but now called the Methow stage. It is also identified by (x. O. Smith. The characteristic topographic type of the Methow stage was a plain, upon which residual hills survived. Following Davis, it may be designated a peneplain, with monadnocks.

Within this plain were carved valleys which appear to have attained nearly mature development That of the Columbia in profile No. 1, Pl. XIX, appears to have been 2,000 or 2,500 feet deep and 7 or 8 miles wide. The smaller streams certainly developed shallower and narrower valleys, hut remnants of the Methow plain west of the Columbia were few and limited. On account of its preservation in the basin of the Entiat, this stage is named from that river. The characteristic topographic form of the Entiat stage is mature. It occurs as a spur or divide below occasional residuals of the Methow stage and above features of later stages.

Within the rolief of the Entrat stage there were cut deeper channels, some of them canyons of impressive depth, many of them simply mountain ravines. They constitute the most marked and everywhere the most characteristic features of the topography of the region. Any large stream might be chosen as exhibiting the type, but probably none shows it in various degrees better than the Twisp, which from its junction with the Methow to its source in the Cascades lies in a canyon that varies from a few hundred to 4,000 feet in depth, as can be seen on the Methow topographic 
atlas sheet. This stage is accordingly named Twisp. The characteristic of the Twisp stage is a canyon, the typical feature of topographic youth, but the development progressed far toward maturity.

The Twisp stage closed with accumulations of glacial ice, which occupied the canyous and in many instances greatly modified them. Rivers overloaded with drift filled their channels to greater or less extent. Lake Chelan and the terraces of the Columbia. near its outlet afford the most conspicuous examples of these phases of activity. This stage of glaciation will accordingly be called the Chelan stage.

With retreat of the glaciers to the highest amphitheaters of the mountains the streams began to reexcavate their channels. The glaciers still linger, and the rivers are still engaged in removing drift. To complete the sequence of stages, this latest and present one may be designated from a stream which flows from several surviving glaciers and is clearing its old valley of drift, the Stehekin.

It is somewhat difficult to place these several stages in geologic time. On the evidence of fossil plants from the Ellensburg formation, the Methow plain in the Yakima district is post-Miocene. The data are fully presented by G. O. Smith, and the unity of the feature throughout the Cascade Range is discussed by the writer under its proper head below. The very long time required to accomplish such extensive and uniform leveling appears reasonably to occupy most of the Pliocence and to bring the date of the next stage near the close of that epoch.

The line between the Pliocene and Pleistocene can not be fixed with certainty. By definition Pleistocene begins with and dates from the earliest Glacial epoch. In the Puget Sound Basin there are deposits of two glacial advances with those of an inter-Glacial epoch, but in the region of glacial erosion and on the eastern side of the Cascades generally the observed record is of one advance only. The relation of the repeated record to the simpler one has not been made out. They may correspond to the same time interval, during which in the lowlands of Puget Sound there was an epoch of glacial retreat not marked in the mountains. In that case glaciation of the canyons covers the whole time of glaciation and all glaciation was later than that of canyon cutting. In other words, the Twisp stage was pre-Glacial, and therefore pre-Pleistocene. On the other hand, it is equally probable that glaciation of the heights as now recognized corresponded only to the later epoch which is recorded in the Vashon till of Puget Sound. An earlier epoch of glaciation, that of the Admiralty till, in that case occurred also in the Cascades, but has not been made out. Its record may not be recognizable if the Twisp stage of energetic erosion corresponded with the inter-Glacial episode. On that hypothesis, the Entiat stage may have been early Pleistocene. 
The following tabulation expresses the most reasonable estimates of correlation for the several stages in geologic time.

Physiographio development of the Cascade Range.

\begin{tabular}{|c|c|c|c|c|c|}
\hline $\begin{array}{l}\text { Physio- } \\
\text { graphic } \\
\text { stage. }\end{array}$ & 'Type locality. & $\begin{array}{c}\text { Nature of characteristic } \\
\text { activity. }\end{array}$ & $\begin{array}{c}\text { Date, if one un- } \\
\text { interrupted } \\
\text { Glacial epoch. }\end{array}$ & $\begin{array}{c}\text { Date, if two or } \\
\text { more Glacial } \\
\text { epochs. }\end{array}$ & Period. \\
\hline Stehekin & $\begin{array}{c}\text { Stehckin sources and } \\
\text { valley. }\end{array}$ & $\begin{array}{l}\text { Glacial retreat and reexca- } \\
\text { vation of old valleys. }\end{array}$ & $\begin{array}{c}\text { Post-Glacial to } \\
\text { present. }\end{array}$ & $\begin{array}{l}\text { Post-Glacial to } \\
\text { present. }\end{array}$ & Recent. \\
\hline Chelan & $\begin{array}{l}\text { Gorge of Lake Chelan } \\
\text { ard terraces of the } \\
\text { Columbia. }\end{array}$ & $\begin{array}{l}\text { Glacial occupation of can- } \\
\text { yons, canyon modifica- } \\
\text { tion, and valley filling } \\
\text { by overloaded streams. } \\
\text { Glacial diversion of } \\
\text { streams. }\end{array}$ & Glacial epoch .. & $\begin{array}{l}\text { Latest Glacial } \\
\text { epoch. } \\
\end{array}$ & Pleistocene. \\
\hline Twisp. & $\begin{array}{l}\text { Canyon of the Twisp, } \\
\text { Methow quadrangle. }\end{array}$ & $\begin{array}{l}\text { General acceleration of cor- } \\
\text { rasion, resulting in exca- } \\
\text { vation of canyons and } \\
\text { ravines with readjust- } \\
\text { ments of drainage. }\end{array}$ & Pre-Glacial. & Inter-Glacial . & $\begin{array}{l}\text { Pliocene or } \\
\text { Pleistocene. }\end{array}$ \\
\hline Entiat & $\begin{array}{l}\text { Basin of the Fntiat and } \\
\text { foot spurs of the Chelan } \\
\text { Runge. }\end{array}$ & $\begin{array}{l}\text { Development of mature } \\
\text { topography generally } \\
\text { throughout the Cascade } \\
\text { plateau. }\end{array}$ & Pre-Glacial & $\begin{array}{l}\text { Earlier Glacial } \\
\text { epoch. }\end{array}$ & Gai \\
\hline Methow . & $\begin{array}{l}\text { Generally throughout the } \\
\text { broad mountain dis- } \\
\text { trict, and specifically } \\
\text { in Yakima Valley. }\end{array}$ & $\begin{array}{l}\text { Planation by erosion to a } \\
\text { low plain with monad- } \\
\text { nocks. }\end{array}$ & Pre-Glacial ..... & Pre-Glacial ..... & Pliocene. \\
\hline
\end{tabular}

\section{METHOW STAGE.}

CONDITIONS OF JEVELOPMENT.

The characteristic feature of the Methow stage was a plain, and where now recognized the essential form of the remnants is a flat, or approaches a flat, from which the existing surface is immediately derived. The plain might have originated through (a) marine deposition, (b) marine planation, (c) as the original surface of a lava flow, $(d)$ by erosion to a peneplain.

$(a$ and $b$ ) Marine deposition and planation are excluded from among the possible conditions of development of the Methow plain, because the surface extended over hundreds of square miles without being in any way conformably related to any sedimentary formation, and is cut unconformably across the bedding of the youngest sediments of the district, the Ellensburg formation.

(a) The original surfaces of Miocene basalt flows probably coincide with the Methow plain in some areas of the Columbia Basin, and it has been thought that these coincidences were so extensive that the plain was determined by the basalt, at least as far as the flows extended. The writer's local observations about Waterville and west of the Columbia are not satisfactorily definite in this regard. At the one point where dip of the basalt could be seen in the Entiat Mountains there is a slight unconformity, but generally no good observation was possible. In the Yakima district, however, where the evidence of coincidence was thought to be most striking, G. O. Smith has observed a general unconformity, which, though commonly slight, 
is often considerable, and, though the angle of divergence be small, it is sufficient to carry the plain diagonally across the great thickness of the basalts, from older to later rocks. Thus in a broad view the unconformity is unmistakable, and the plain is not identical with the surface of the lava flows.

(d) The extent of the Methow plain as observed by Russell and the writer is more than 10,000 square miles. It has been identified by Russell, Smith, and the writer as a feature cut upon nearly all rocks of the region, the schistose metamorphics, the Tertiary arkose sandstones, the bedded basalt flows, and the pumaceous clastics of the Ellensburg formation. These facts are consistent with but one interpretation, that of widespread planation by agencies of subaerial erosion to a plain approaching base-level. The Methow plain, therefore, represents a flat lowland. The plain has been observed not to agree with nor pass over some summits of granite, granite-porphyry, rhyolitic porphyry, and other intrusives. These eminences are regarded by the writer as monadnocks, which mark a certain degree of incompleteness in planation.

Criteria of recognition.-The characteristics by which areas of the Methow plain are identified are flatness, unsympathetic relation to environment, and relative elevation. Flatness is not used in a mathematical sense. No topographic feature is a plane, and it is not probable that any area of the old plain survives with unmodified surface. An approach to flatness is all that can be looked for, Flat does not mean level. The old plain had indeed a very low slope, but in course of elevation to the altitudes at which it is now found- $-3,000$ to 9,000 feet--it has acquired relatively steep inclinations at some places.

An unsympathetic relation of a topographic feature to its environment is that relation in which the feature could not develop or in which the prevailing activities are working to destroy it. An elevated flat crowning steep slopes is in an unsympathetic relation to its environment. Less obviously, but not less truly unsympathetic, are long, smooth slopes and spurs subject to attack by streams retrogressively developing their channels. In the usual case the unsympathetic feature is a residual, which still retains in part a surface developed under a different environment, but where the original surface is all eroded the unsympathetic form may. still be seen in inherited features or relations. Thus uniform elevation of mountain summits is interpreted as inheritance from a plain which was dissected in consequence of elevation. The uniformity is not in sympathy with the height. There are, furthermore, degrees of unsympathetic relations. The extreme is that existing between a plateau and a canyon, between passive age and aggressive youth. Of a less degree is the diversity between a wide or rounded ridge crest and slopes which approach maturity. And canyons cut in maturely developed topography afford examples of least conspicuous unsympathetic relations 
Relative elevation is an important factor in recognizing remnants of the Methow plain, but in this respect elevation above sea is less significant than position above other features. Since in course of physiographic development an older residual feature commonly lies above all younger forms, we should look for remnants of the plain, the oldest surviving phase, at the greatest altitudes in any locality; but where the plain falls below any summit we are constrained to recognize the latter as a residual, or monadnock, upon the plain.

Distribution and character of residuals.-Detailed geologic surveying with adequate base maps has been carried out in the Cascade province chiefly by $G$. $O$. Smith. His identification of the Methow plain in the Yakima province is described by him in the earlier part of this paper, to which the reader is refered. In what follows the plain is traced in the district between Wenatchee and Methow and in portions of the high Cascades seen by the writer.

The distribution of recognized residuals is shown on the maps, PIs. XVI, XVII, and XVIII. The mapping is an adaptation of observation to base map, carried out in the office and largely guided by the topographer's delineation of forms. Exact boundaries can not be recognized in the field, except occasionally for short spaces, and none are attempted in the graphic statement. The areas delineated as representing the Methow plain are not thought ever to correspond exactly in surface with it. They have been modified slightly by corrasion and materially by disintegration and wind erosion; but they retain the typical character of the plain sufficiently to demonstrate its former existence and to represent it.

In the Waterville plateau wide areas are characterized by flatness. They occupy the positions of broad divides and are commonly distinguished from lower, gently sloping surfaces by an intermediate steeper facet. They are unsympathetic to the slightly accented drainage channels, and they fall into one general plain. They probably correspond nearly with the surface of basalt flows, but no outcrops of the rock were observed, deep soil prevailing everywhere within sight of the writer's route except on the scarps toward Columbia River. Their great extent removes them from the category of surfaces possibly due to rock structure only, and their other characters identify them as residuals of an ancient lowland plain of erosion.

Two isolated hills southeast of Waterville and the nearby spurs of Badger Mountain are believed closely to approach the flat of the Methow plain. The spur east of the main road from Waterville across the mountain most nearly continues to the summit an unbroken surface, which may be considered representative. The top of Badger Mountain has the character of the Waterville plateau, and long, even spurs extend this aspect into the valley of Rock Island Creek on the south. Independent physiographic evidence of Columbia Canyon and some meager structural facts show that the mountain is an anticline of later development than the 


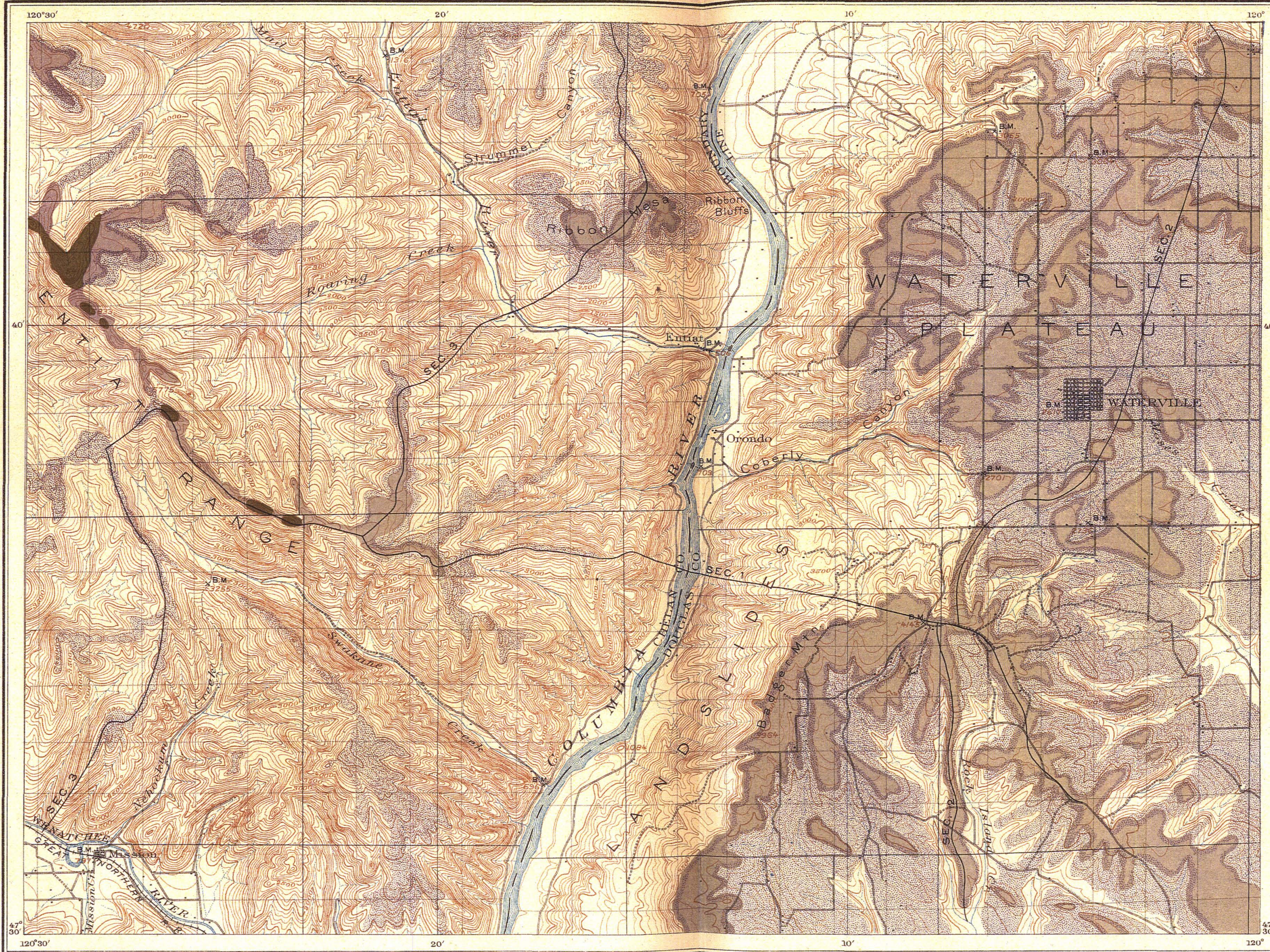


Methow plain, which should accordingly rise above the arch or to a greater or less degree coincide with it. In general profile the coincidence appears to be close; the summit and southern slopes are probably not much modified; but the northern slope is dissected untıl very little, if any, part of the surface represents the plain.

South of Rock Island Creek the characteristic broad expanses extend to the escarpment above the Columbia gorge and their sky lines are continuous across the canyon with the heights of Table Mountain, from which they descend to the Yakıma Valley.

The Methow plain west of the Columbia is preserved in a few small remuants only. The even slope on hasalt in the eastern end of the Entiat Mountains, 4,800 to 4,900 feet above sea; Ribbon Mesa, 3,300 feet; spurs above the contour of 3,400 feet on the hill, which reaches an elevation of 3,747 feet; and Fourmile Ridge, 6,700 feet, have all been described. They are topographic tlats which are on the whole not determined by structure planes of the basalt, where there is basalt, and which occur on jointed and schistose rocks as well, which are not in sympathy with their present environment, and which have, to later topographic stages, the relation that the Cascade plain holds. Therefore, in spite of their considerable and diverse altitudes, they are identified as residuals of that once continuous lowland.

It is possible that detailed study of the Chelan Mountains between Baldy Mountain, Ribbon Mesa, and Chelan Butte will discover other bits of the plain on summits of spurs and about monadnocks. There is room for question whether the hill which rises to an elevation of 3,757 feet is a monadnock or not. The plain may sweep above it, but the general interpretation of facts would not be modified in any essential particular by such changes in the determination of local positions.

Of the Methow Mountains the writer has not seen the portion east of Navarre Peaks except in general views trom a distance. Therr profile thus seen is characteristically that of a tilted, somewhat dissected plain. They rise with continuous line from the plateau level east of the Columbia from 3,400 feet or less to 6,000 feet above sea. They then appear to sweep up in a steeper but moderate grado to the heights of Navarre Peaks at 7,800 feet. The topographic map and the profile derived from it (fig. 4 , Pl. XIX) confirm this observation. Along the crest, from 3,400 to 6,000 feet above sea, there are residual surfaces of flat form unsympathetic to their environment. One extends from 3,600 feet to 3,800 feet. There is then a sise over Cooper Mountain, which is probably a monadnock, about 300 feet above the plain. Beyond this the flats occur near or above 5,600 feet, with ascent to 6,100 feet, and thence upward the crest is sharp. Navarre Peaks might be regarded as summits older or younger than the flat surfaces--as 
monadnocks or descendants; ${ }^{\prime}$ but, considered in their relations to the many heights of about the same altitude which occur west of them and connect them with the general level of the high Cascades, Navarre Peaks appear to be descendants, and the plain sweeps up to and over them.

The reconstruction of the Methow plain bas proceeded thus far upon identification of residuals, which actually or so nearly represent its surface that they may be taken for it. In extending the reconstruction further over the Methow Mountains and the high Cascades, another line of reasoning must be followed.

In the Cascade Range views from high altitudes present two striking features, that mutually are in strong contrast. The one is the acuteness of the mountain forms, often sharply needle-like; the other is the uniformity of general elevation which these boldly sculptured peaks approach. The sharp forms result from the activity of frost and thaw, of corrasion, and of transportation in shattering and removing rock masses, whose principal controlling structure is steep jointing. The uniformity of heights has been interpreted as inheritance from a former plain surface, and also an effect of erosion at great altitude.

The latter hypothesis has been considered in view of facts closely resembling those observed by Dr. Dawson, its author, in the same mountain range, but it does not seem to be sustained. The activities of erosion do not appear to tend toward more uniform effects with greater altitude, on the contrary elevation emphasizes their locally unequal intensities. Corrasion and transportation are effected by falling water, whose energy for a given mass is directly as the fall, and consequently increases with height of land. Corrasion and transportation are very narrowly localized in activity, and hold the same relation to general degradation that a circular saw does to a planer. Their intense application results in deep canyons, the extreme of height and depth. Disintegrating influences, whether chemical or mechanical, may act equally with equal opportunity, but they are controlled by conditions of exposure. Upon an uneven surface these are varied and they become more and more diverse as inequalities of relief develop. The suggestion that frost and thaw may with elevation gain in effectiveness more rapidly than corrasion and so may limit the height to which peaks may attain in a growing range, appears not to be sustained by study of mountains much higher than the Cascades, nor by theoretical reasoning in regard to the work of freezing water. Thus after careful consideration the writer has felt obliged to abandon the hypothesis of development of a common high level among mountain peaks.

The general level of Cascade summits is suggested in the views, Pls. IX and X. The one is the central section of a panorama of three views, looking southwest

$a_{A}$ desccndant is a topographic feature carved from the mass beneath an older topographic form which has been removed. 

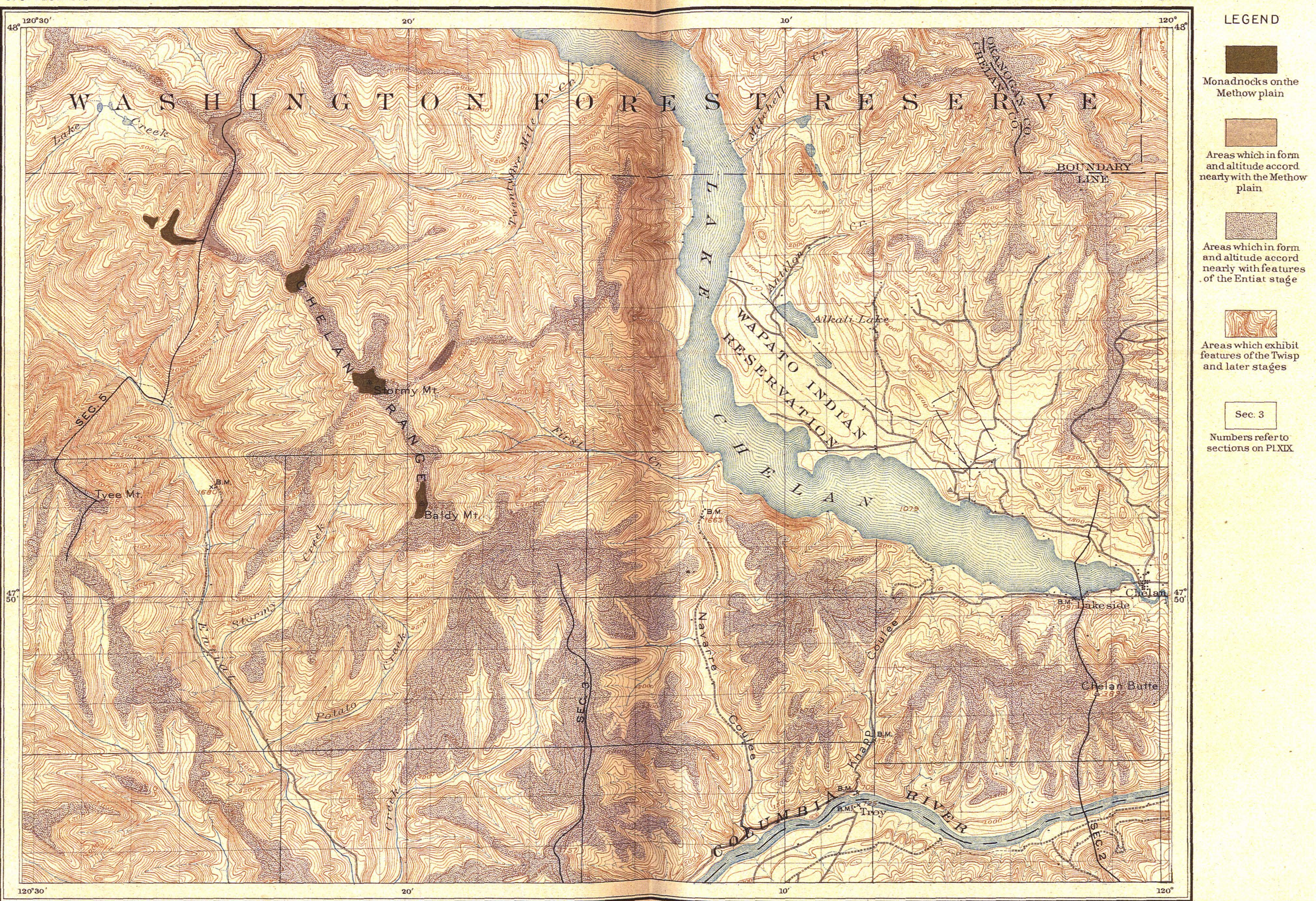
from th; head of a tributary of the Yakima across spurs of the range. The other is a view down Stehekin Valley to the distant Methow Mountains. In neither case does the photograph give the full effect of these landscapes; the angle is but 50 degrees of the full circle, of which the greater part may in a central situation show similar effects, and in each of these particular cases the camera was 1,000 feet or more below the peaks, which consequently appear higher near by. To see such a surface of common altitude the eye should be in it. A diagrammatic presentation of the fact of nearly uniform altitudes is given in the profiles of the Methow Mountains west of Navarre Peaks. (Figs. 4 and 5 of Pl, XlX.) Of the dozen or more summits represented in as many miles, none is lower than 7,800 feet and only one, Star Peak, rises to 8,500 feet above sea. While this diagram gives but a single line, several profiles across the range might be constructed showing similar relations of mountain tops on spurs which extend 3 to 4 miles from the central divide.

The fact of uniformity of summit level becomes more and more impressive as it is observed over wider and wider areas. Russell and the writer have found it to extend over practically all of the high Cascades, occurring at altitudes which vary from 6,000 to 8,500 feet according to the portion of the range in view. There will probably be little if any dissent among future observers from the inference that this widespread equality of heights is derived from a landscape of gentle relief, but opinions will differ as to the degree of plainness of the ancient surface. The occurrence of granite monadnocks, such as Mount Stuart, rising a few hundred feet above the probable position of the old plain, is significant in this connection. Were they numerous they would indicate a billy region, but far apart as they are and of moderate altitude they suggest that planation had made general progress toward a low peneplain.

The present altitude, which the plain would have above the mountain tops if it existed, is yet to be carefully estimated. In that portion of the Methow Range which has been topographically mapped and studied, the summits near and above 8,500 feet (Star Peak, 8,500; Oval Peak, 8,800) have broad, rounded forms. It is possible that they rose to, if not above, the Cascade plain in this vicinity. On the assumption that the altitude of the plain would now be about 8,500 feet, the inherited summits lie 200 to 600 feet below it. This is probably a minimum. On the other hand, if Mount Stuart and similar granite cones are monadnocks, the plain can not well be reconstructed more than 1,200 feet above the ridges which surround them.

ENTIAT STAGE.

PHY'SIOGRAPHIC RELATIONS.

The physiographic relations which constitute the chief criteria that serve to identify features of the Entiat stage are those of a development intermediate between an older and a younger stage. In position and in form Entiat residuals lie between the flats of the Methow plain and the canyons of the Twisp stage. 
The Entiat stage was first recognized by the writer in riding from Wenatchee up the Columbra gorge and over the high spurs between it and Entiat River. It then became evident that the Columbia Valley consisted of at least two parts, an inner canyon and an outer valley, a younger and an older phase; and above the older were found the surfaces identified as parts of the Methow plain In extending the observations it was found that a distinction must be made between those parts of the Cascades which had been subject to much precipitation and consequently had suffered deep corrasion, and those which had recenved slight precipitation and had been but faintly engraved. This difference of sculptures in Entiat time is parallel with the present diverse aspects of corresponding areas of great and little ramfall

The criteria by which Entiat and Methow features are distınguished have already been stated. Where they hoth occur adjacently, the former lie helow the latter and in unsympathetic relations. The distınguishing point between Entiat and Twisp slopes is a more or less prominent projecting angle or bench Its significance depends upon the fact that in homogeneous material normal profiles of a continuous cycle are concave upward. The curve or angle which is convex upward or outward may result from rock differences or from glaciation or from revival of stream activity; the first is commonly a local, the others general phenomenon of anr particular district. Along the western side of the Columbia the gneiss and granite are unlike in detar, but in general they are homogeneous in their attitude toward erosion agencies. The hills have not been glaciated, nor did glacier's of the latest epoch extend so far down either the Columbia or Entiat Nevertheless, each of the

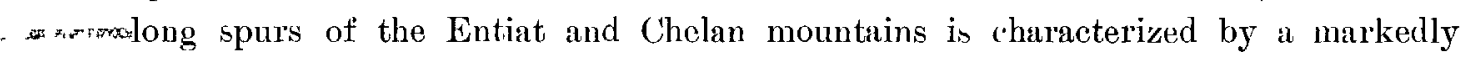
prominent angle, and in the ravines a corresponding change occurs at the top of a steep stream grade or fall. In all the unglaciated heights west of the Columbia, this angle in a prominent, and significant feature. In glaciated slopes the older records cut by the streams are modified hy ice work, and the features are more complex

IHSTRIJUTION AND CIARACTER OF RESHUUAIS

Featuin such as are characteristic of the Entiat stage exist generally throug hout the higher Cascades, so far as the writer's observation goes, but ressduals, in the sense of unmodified forms, probably do not survive to the same extent as do those of the Methow stage, if at all. This follows from the greater effectireness of erosion on slopes as compared with that on plains.

Represcntative Entrat features are rounded or flat ridges, spur', and gentle slopes, commonly distung uished by a covering of deep soll, as well an by their physiographic relations. To enumerate them would be to repeat much that has been said in describing the ranges, but typical examples may be cited. In the eastern end of the Entiat Mountains the spurs, which extend at about 4,700 feet from the that of 


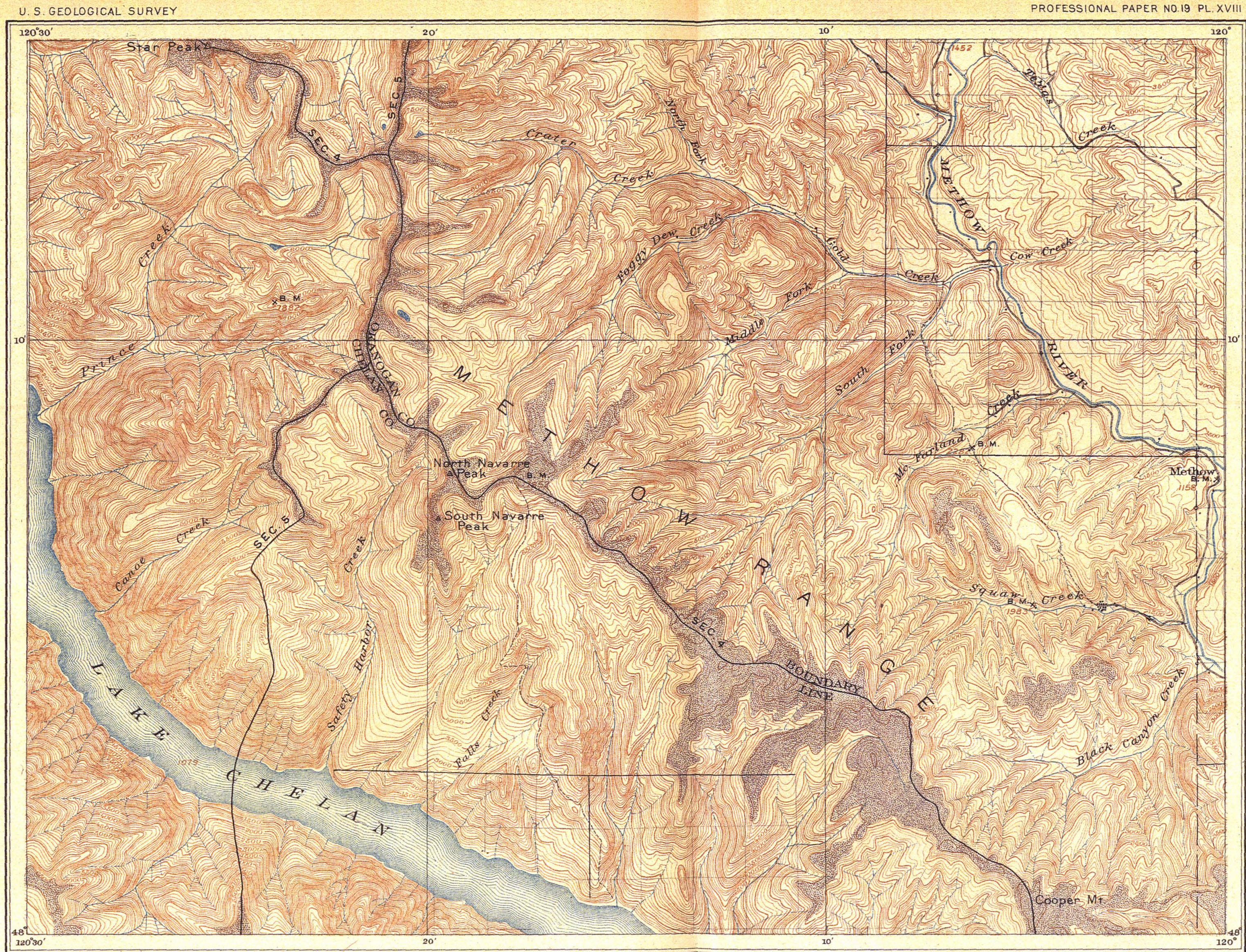

LEGEND 
Methow date down to about the contour of 2,600 feet, exhibit typical Entiat profiles. (See profile 1, Pl. XIX). The ridge isolated by Lake Chelan, Columbia River, and .Knapp Coulee is a characteristic Entiat form in its summits and spurs above the 1,500-foot contour. (See profile 2, Pl. XIX.) The rocky height of Chelan Butte is probably a monadnock of pre-Methow date, but the development of Entiat features has gone so far as to remove the plain from about it. The slopes of the ridge are scored by numerous ravines, in which corrasion has progressed steadily during all the time since the Entiat epoch closed. They are therefore more deeply cut than formerly, having steeper grades toward the top. In their lower channels they bave been materially modified by deposits of the Chelan glacial epoch.

The profile 3, Pl. XIX, exhibits Entiat slopes in relation to the forms that preceded and followed them. The long spur between Mad Creek and Tyee Mountain, 3,500 feet to 6,500 feet; the spur of the Chelan Mountains, 5,500 feet to 6,700 feet, and those of the Methow Mountains above 6,000 feet, along this section line, are reasonably near: Entiat features. They exhibit the long concave curve, the windgaps, and the rounded summits, for the most part deeply soil covered.

There may be features whose age is indeterminate because their aspects and relations are capable of more than one interpretation. Such a one is the flat spur contoured by the 3,000-foot line west of Navarre Coulee and rising by gentle grade to the mountain which has an altitude of $3,75 \%$ feet. If of Methow date, it is a part of the plain marked out around the last-mentioned mountain near the 3,500-foot contour, and its inferior position is due to warping. If of Entiat date it is a low level of an early epoch in the widening of Navarre Valley; and in that case, also, it may, in consequence of warping, now occupy a position lower than it had in relation to the Chelan Mountains. Were the ridge continuously broad and gentle of slope from the mountain having an elevation of 3,757 feet nearly to the top of the Chelan Mountains east of Baldy, the former date would seem probable; but the hill crowned by the 3,500 -foot contour and several interruptions of the gradual slope by steeper intervals indicate that the plain was eroded, and we have to deal with an Entiat surface which locally developed a flat feature.

DECIRET OF FNTIAT JELIEF,

West of the Columbia the differences of elevation covered by features assigned to the Entiat stage are considerable: In the eastern portion of the Entiat Mountains, from 2,600 feet to 4,700 feet; in Chelan Butte, from 1,600 feet to 3,700 feet; in the district west of Navarre Coulee, from 2,000 to 6,000 feet; in Tyee Mountain, from 3,500 to 6,600 feet; in profile across Lake Chelan from Fourmile Ridge to the Methow Mountains, from 6,000 to 7,700 . These variations occur not only in different places, but on slopes which decline in different directions, and some part 
of the apparent relicf is attributed to deformation. We may therefore distinguish between those which apparently have not and those which have been tilted.

The spur which descends at the eastern end of the Entiat Mountains connects a well-preserved Cascade flat with the gorge of the Columbia, the largest stream. Lying on but parallel to an axis of uplift, its inclination has not been affected appreciably by warping, and its relief-2,100 feet-may fairly be taken as representing the facts at that place in Entiat time. The spurs of the Chelan Mountains extending north from Fourmile Ridge and those of the Methow Mountains opposite them are apparently once continuous parts of a profile now inter'rupted by Chelan Canyon. They do not exhibit evidence of depression or tilting toward the canyon, and their degree of relicf-1,700 feet-is probably not greatly different from what was the maximum in Entiat time at that point.

The long slopes which rise 3,000 feet and more to Tyee Mountain and to the Stormy Mountain ridge are apparently not in their original attitude. The elevations of Cascade residuals and the canyons cut in these ranges show that the heights of Tyee and Stormy are due in part to local as well as to general uplift, and that the Entiat features have shared in the change of attitude. In a less degree this is believed to be true also of the Chelan Butte ridge.

GLACIATED ASPECTS OF ENTIAT HEIGH'TS.

Where extended masses occur at high altitudes in the Cascade Range, the togographic features may be classed as four in number: (1) Dominant peaks, usually acute in form; (2) high serrate ridges and spurs, which are often very narrow; (3) elevated amphitheaters of characteristic glaciated form; (4) canyons, usually also glaciated. Those dominant peaks which rise approximately to a common altitude or higher are considered to be descendants of the Methow. plain and its monadnocks, as already stated. Similarly, but even less adequately, the serrate ridges and glacial amphitheaters represent features of the Entiat stage. They are developed in masses which were not deeply cut by canyons of the Twisp stage, but those masses may probably have been sculptured into valleys and divides during the Entiat stage. The alternative is to assume that degradation of the Methow plain to post-Chelan aspects of glacial sculpture was accomplished without any intermediate stage of - aqueous erosion. This view possibly might resonably be held were not the Entiat stage clearly recognizable in the unglaciated area. Since the latter is the case, however, it is logical to infer the development of valleys and ridges of Entiat date, from which glaciated amphitheaters and their tangent arêtes are derived.

MATURITY OF ENTIAT TOPOGRAPHY.

In the usual threefold division of a topographic life period into youth, maturity, and old age, maturity may be used in either one of two senses, namely, to describe 


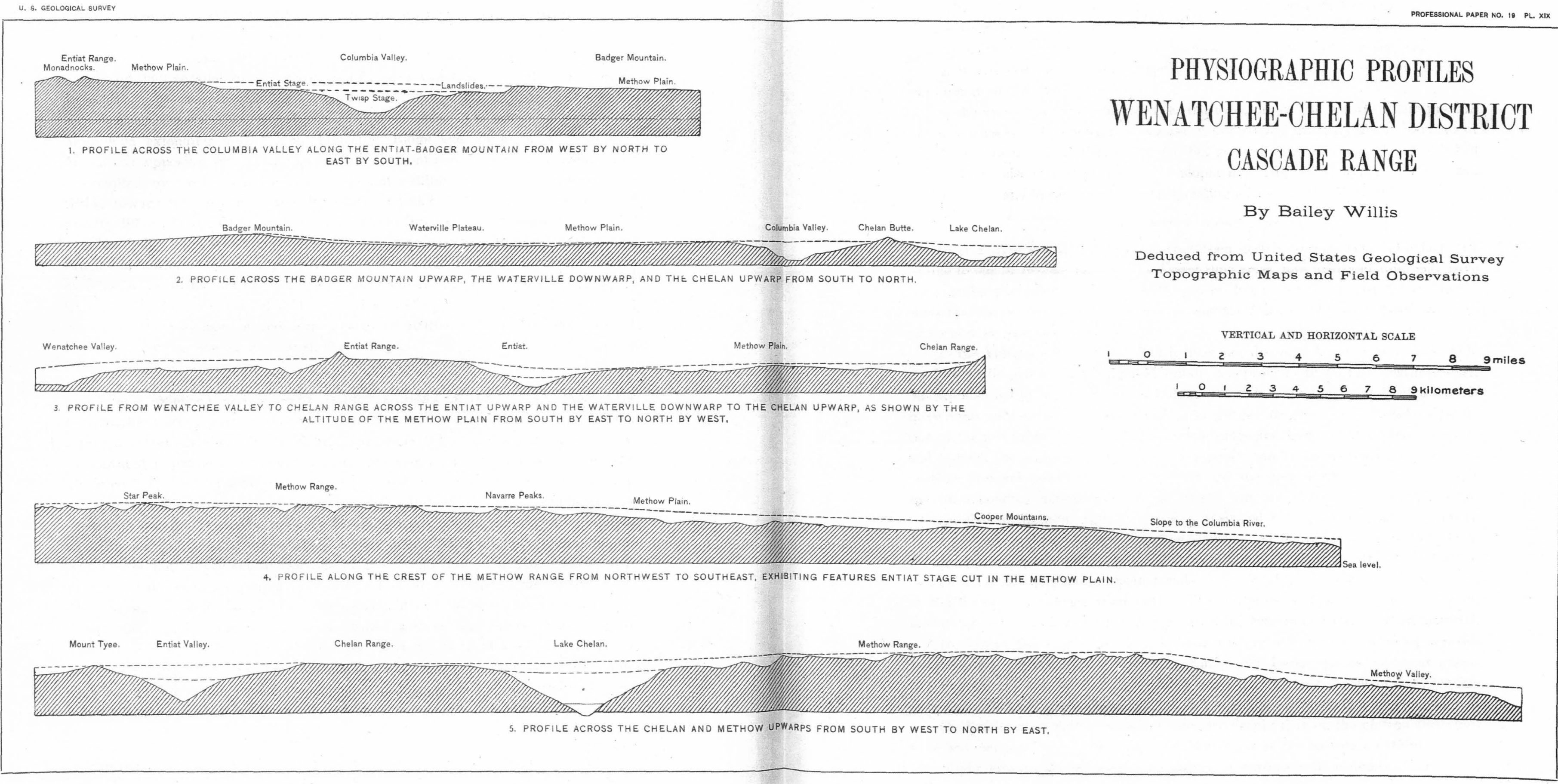


a long mid-interval during which the prevailing features are narrow divides, steep slopes, and $\vee$ valleys; or, second, to designate with precision that exact date at which a given residual of an earlier stage is reduced to nothing and the divide begins to dwindle under the attack of opposed headwaters. In the latter sense maturity at any particular date is a term of strictly: local application, since residuals do not all succumb at one time.

In the broader sense of the word, Entiat topography was mature where precipitation was heavy. In the narrower sense, it approached maturity about residuals of the Methow plain, where they still exist, but generally outside the arid region it had passed the precise instant of mature development. That is to say, the divides had become sharp and lower than the corresponding surface of the Methow plain.

ENTIAT FEATURES IN ATRD AREAS.

In arid areas Entiat features have not been clearly recognized: This fact may be due to one of two conditions. In Entiat time areas now arid and high may have been similarly situated, or they may have been low. In the one case aridity, in the other lowness, would have limited erosion, and the features which developed would in either case be inconspicuous.

In the Yakima district G. O. Smith does not distinguish the Entiat stage. On the Waterville plateau and Badger Mountain it is probable that Entiat features exist, but are mantled by later deposits and obscured. The valley of the Columbia bounds these areas on the west. Its inner and outer gorges are less conspicuously separate east of the river than west of it, because landslides have generally modified the scarp, and to them the suggestive details of the profile might be ascribed; but the two episodes of development are distinguishable on the east in appropriate relations to the corresponding details west of the river. On the platean there occurr, below residual flats of Methow date, long spurs separated by lightly engraved channels. Their contours and profiles are round and gentle. They appear nowhere to be composed superficially of hard rock. Soil derived from basalt and a soft sand deposit of unknown age and origin were the materials seen. Well-filled angles and fluent curves of the landscape evidence wind work. The sculpture is that of aqueous erosion, moderately developed, and later modified by wind erosion and wind-drifted material.

In view of the stages elsewhere found, it is probable that the work of aqueous agencies was accomplished during the Entiat and Twisp epochs, and that effects of mantling are due to conditions which prevailed during the Chelan and Stehekin (Glacial and post-Glacial) stages.

On Badger Mountain ravines are cut more deeply than on the plateau and winds have had comparatively little effect; yet the slopes of the nountain exhibit remarkably slight erosion as compared with the heights west of the Columbia. It will be 
shown in discussing deformation that the elevation of Badger Mountain above Waterville plateau is chiefly a growth of post-Entiat date, and therefore Enitiat features are inconspicuous on the mountain, and what dissection has occurred there is of Twisp age and later.

TWISP STAGE.

CHARACYMRISTIC FEATURES.

Canyons are the prevailing valley forms of the Cascade province. In elevated districts they are profound and numerous, and, having the $U$ section due to glaciation, their volume represents a large part of that of the original uplifted mass. Between the glaciated and arid districts lies the zone of simple but energetic aqueous erosion in which unmodified canyons are most strikingly developed. In the arid region, the central plateau of Washington, canyons are deeply cut in the basalt. The most conspicuous, such as Grand Coulee, are ascribed to diversion of the Columbia during glacial time, and if that be true, do not belong to the stage here to be discussed.

The inner gorge of the Columbia between Wenatchee and Methow is a steep-sided channel cut below older topographic features in the bed rock mass of the region. Its position and proportions are such in relation to the river that there can be no doubt that the master stream cut it out. Glacial striæ were found by Salisbury on its western wall just above Chelan Ferry. A morainic terrace occurs on the eastern bank a mile below Chelan Falls, and from this southern limit of the glacier a very conspicuous system of river terraces, composed of glacial drift, extends down the valley. The gorge is, therefore, of aqueous origin and was carved prior to the latest glacial cpisode. As such it is a representative canyon of a pre-Glacial stage. It lies within and clearly distinct from features ascribed to the Entiat stage, and its development thus occupies an interval of time between the Entiat epoch and glaciation.

A geographic name for this stage can not well be chosen from this typical section of the Columbia Gorge, the desirable names having been applied to other uses, but it would appear from the topographic map of the Methow quadrangle that Twisp River has worked out a channel scarcely less characteristic, and the name is selected accordingly.

DEVELOPMENT OF TOPOGRAPHIC FORMS.

The Twisp cycle of topographic development was interrupted at an early phase by the advent of glacial conditions. The survival of Entiat and Methow residuals and the effects of glaciation sufficiently demonstrate this fact.

Columbia Canyon, between Wenatchee and Chelan, was cut to its present depth by aqueous corrasion before the latest Glacial epoch, since it is occupied by drift, which the river has removed down to bed rock at various points along its channel. The 
canyon walls receded to some extent during Glacial and post-Glacial time, and the amount of recession is shown to be appreciable by the fact that cliffs above Chelan Falls, past which a glacier extended and over which it rose, now exhibit pinnacled profiles that have developed since the ice withdrew. But the occurrence of glacial striæ near the summit and on the river side of the cliffs indicates that the form of the canyon was not greatly different then from what it now is. This is within less than 2 miles of the end of a tongue of the wide-spreading glacier which came from Methow and Okanogan districts. The ice was probably nearly stagnant and ineffective.

In the glaciated region of the higher Cascades, the canyons are developed on a grand scale. Russell has rightly described them as extending with channels at railroad grades into the very heart of the mountain mass, and they are from 1,000 to 3,000 feet in depth. They have been widened and deepened by ice work, to what degree is yet to be determined, but apparently in some instances greatly. Nevertheless, when all reasonable allowance has been made for glaciation, the canyons which may be ascribed to corrasion during the Twisp stage were of great depth. They were relatively narrower than they now are, and their topographic development had the character of advanced youth.

\section{CHELAN STAGE.}

CHARACTER OF THE RECORD.

The climatic conditions of the Chelan stage interrupted the topographic cycle of the Twisp stage. They induced glaciation, and occasioned very pronounced phenomena of glacial erosion and glacial construction, the latter including extensive deposits from overloaded streams. Russell has already described these features in a preliminary way, and they bave been touched upon incidentally in this article. The general facts are conspicuous, have been widely observed, and are published. It is expedient here to discuss only one fact, the depth of Lake Chelan, which has a possible relation also to the question of deformation.

THE BASIN OF LAKE CHELAN.

Lake Chelan occupies a canyon in granitic and gneissoid rocks. The waters are retained by a dam of drift, but discharge through the gorge of Chelan River into the Columbia, whose bed is not far from solid rock. According to the altitudes above sea of rock in place in the Columbia several miles below the junction, that of the lowest rock sill over which the waters of Lake Chelan can have escaped is about 700 feet. 'The elevation of the lake's surface is 1,079 feet, and its depth exceeds 1,000 feet through a stretch of 16 miles." The maximum sounding was 1,419 feet, i. e., to 340

a Sounded by Mr. W. G. Steel, at request of Mr. Henry Gannett, for the United States Geological Survey. MS. records. $14493-$ No. $19-03--6$ 
feet below sea level, or 1,040 feet below the rock rim of the basin. The depths are given on the map (Pl. XVII), and they present an interesting problem in the question, How did the lake channel become so deep?

According to the physiographic record, the Chelan channel developed by stream robbing and became a river canyon through the usual effects of stream action, which are, however, incompetent to have so greatly deepened it. It may have been deepened by faulting or glacial erosion.

Faulting is not readily capable of direct proof or disproof in the rock structures of gneiss and granite. There is, however, throughout the Chelan-Stehekin system of channels a unity of form, which strongly suggests unity of development, and through which any hypothesis of faulting as a condition of the Lake Chelan canyon should be extended to its tributaries; but the ramifications of the system and the slenderness of the supposed downthrows are such that the hypothesis is untenable. If the area of faulting be restricted to that of excessive depth in the Chelan Basin, there is a similar peculiarity of form in the supposed downthrow and no evidence to support the proposition. We may turn, then, from the purely theoretical idea of faulting to that of glacial erosion.

Effects of glacial erosion are obvious throughout the Chelan-Stehekin system. They may be traced from the moraines of existing glaciers in the cirques about the headwaters, down the grooved and rounded canyon walls, into the waters of Lake. Chelan, and out to the terminal moraine near the Columbia, in all a distance of 70 miles. Three miles above the terminus of the ancient glacier its thickness was 1,000 feet, and its surface stood about this amount above the present level of Lake Chelan. Thirty miles above its lower end, that is, near Safety Harbor Creek, the thickness of the ice was 4,500 feet, and toward the head of the lake it probably exceeded 5,000 feet. Detailed observations as to the upper limit of glaciation along the lake shore are needed, but the above statements are based upon a few points definitely noted. That this mass of ice was capable of exerting great erosive power can scarcely be doubted, but it remains to be shown that the phenomena of depth of the lake basin bear some logical relation to the probable effects of ice corrasion.

It is believed that the erosive power of ice when moving as a glacier is a function of the volume of ice, the restriction of channel, and the rate of flow. ${ }^{a}$ These factors are, it is true, in a measure interdependent, but it is not important here to separate their influences, as we can not deal with the problem quantitatively. It will suffice to show that the excavation of the channel is proportioned to the amount of ice entering from successive tributaries and that, where the volume is constant, the depth of the channel is inversely as its width. 
The extent of former glaciers in the Chelan-Stehekin system is indicated (with a rough approximation only to the facts, but sufficient for this purpose) in the map (PI. VIII). It may there be noted that the drainage from a considerable area is concentrated at the junction of Stehekin and Bridge creeks, and it is at that point that the headwater canyons pass into a conspicuously wider channel, and that the stream assumes a flatter grade. Just above the junction of Agnes Creek this flat ends in an abrupt descent to a wider and lower valley floor, which extends from Agnes Creek to the head of Lake Chelan. The cross section of the canyon widens slightly, but not notably, and its depth, so far as it may be determined by the soundings in Lake Chelan, increases gradually to the junction of Railroad Creek. Abreastof this stream the valley is considerably wider, and may be regarded as a basin competent to store a considerable volume of ice. A short distance down the lake, near Prince Creek, is the upper end of the Narrows, which extend to Twentyfive Mile Creek. Here the walls of the canyon are steepest, and approach each other most nearly, and here the depth of the lake increases rapidly. Below Twentyfive Mile Creek the valley. opens out and the lake basin rapidly shallows.

There is in the above-described relations that coincidence between width and depth of channel which in the single case might be considered fortuitous, but which, when oft repeated and found to be systematic, presents a strong argument for a relation between cause and effect. While the data are by no means so complete as might be wished, and while a thorough discussion of the problem would require that one should eliminate the effects of glacial and stream filling in order to arrive at a true measure of the depth of the channel, it is not probable that these subordinate factors could change the dominant relations from which it is inferred that the basin of Lake Chelan owes its unusual depth and character chiefly to glacial erosion.

A further test of this conclusion may be applied by contrasting it with other valleys in the same region, many of which have been occupied by glaciers, and none of which exhibit similar peculiarities. A thorough study of the glacial effects throughout the region should shed much light upon the nature of the phenomena, but it may here suffice to say that the Chelan case is exceptional (1) in the large volume of ice contributed from an area of approximately 350 square miles, throughout which the mountain summits range in altitude from 7,000 to 8,500 feet, and (2) in the remarkable depth and narrowness of the canyon through which the glacier was forced.

\section{DEFORMATION.}

Criteria.-The criteria according to which the nature and amount of deformation are commonly determined are of a stratigraphic character. The surface of a stratum, assumed to have been plane and observed to be flexed, is a datum from which changes of form may be deduced. In the area under discussion in the present 
case the rocks are gneisses and intrusive granites, whose structures do not afford dips from which to infer the nature of recent deformation. The occurrences of basalts, which do afford such data in the Ellensburg district, are of no value in the area west of the Columbia and north of the Wenatchee, as their distribution is very limited. Jointing, the commonly developed structure of all the rocks of the district, bas not been so studied as to yield results. It follows that deformation must be investigated upon a different basis, viz, chiefly upon physiographic evidence, through the warped form of the earliest recognized topographic surface, the Methow plain; and the facts described in the account of the physiographic history are thus made use of in the following discussion.

Fundamental propositions.-In the preceding discussion certain principles have been applied in interpreting the relations of physiographic features and deformation, but the statement of those principles has been deferred to this place, where it may form an introduction to the account of mountain growth. In general terms the propositions are as follows:

(1) Mountain growth involves changes of altitude of such vertical amount and such moderate extent as compared with continental areas that elongation of the earth's radii beneath the mountain mass may more plausibly be assumed to account for the elevation reached above sea level than general subsidence of the datum plane. The effect of such elongation is appropriately described as an uplift when the whole mass is considered.

(2) Uplift results in deformation of the preexisting topographic surface, which is elevated in some areas above othors that may be considered relatively depressed. In what follows the term warp will be used to designate deformation of the surface, upwarp and downwarp being employed to describe, respectively, elevated and depressed areas, always the former topographic surface, and independently of the rock structure. The latter is appropriately expressed in the terms anticline and syncline.

(3) Erosion occurs only as a result of change of relative altitude, and its effects are a function of the amount of change.

(4) Other things being equal, the several sections of a river valley between source and mouth are consistently developed, when uplift has been uniform and simultaneous, within moderate limits of variation. Inconsistent sections are evidence of unequal uplift or of uplifts of different dates.

(5) At any particular stage of development in homogeneous rocks the normal grade, or slope, of a plain or river valley is variable within narrow limits only; abnormally steep, gentle, or reversed grades are effects of warping during succeeding cycles. 
CASCADE UPLIFT.

The Cascade Range is an elevated mass which is observed by all who come within sight. Equally recognizable by adequate observation is the wide, tabular form of its surface, as are also the marginal slopes which connect it with lower adjacent surfaces. The gross form, all details of spurs and sculpture being omitted from consideration, is that of a broad uplift, with wide, flat top and sloping flanks.

'The general fact that the uplifted surface has been eroded is obvious, and investigation of the topographic forms shows that they express several stages of development, of which the initial one was an ancient peneplain that extends over the mountain mass. The peneplain having been practically flat and low, according to its origin, and being now elevated in part, there has been warping, the amount and character of which are expressed in any section by the difference between an are of the earth's spheroid at sea level and the flat arch of the uplifted surface. Thus we may describe the Cascade uplift as that broad and flat-topped elevation which lies between Puget Sound on the west and the central plateau of the Columbia River Valley on the east.

Height and extent. - With reference to sea level, the surface of the Cascade uplift, or the upwarp, actual and restored, varies in altitude from 6,000 to 8,500 feet throughout the area of its upper level. The maximum of 8,500 feet is attained probably north of the forty-seventh parallel and is maintained throughout more than one degree of latitude to the forty-ninth parallel. South of the forty-seventh parallel the extent and altitude of the warped plain are not well known, except that at an altitude of about 7,500 feet it forms the platform upon which stands the volcanic cone of Mount Rainier, and probably extends in a similar manner beneath Mount Adams, Mount Hood, and other volcanoes in Oregon. Its altitude probably lessens toward the south, but it is not likely that it falls below 5,000 feet along the broad axis of the uplift. The width of the uplift at its elevated platean level is variable, but is probably rarely less than 60 miles nor more than 100. As may be seen in Pl. I, the eastern margin is crenulated, and in consequence of the fluting the width of the flat top of the upwarp is very variable, and it is possible, as suggested by Smith, that the larger marginal downwarp may extend nearly across the axis or entirely across it.

The further description is limited to the area north of the forty-seventh parallel and more narrowly to the regions which have been described in detail in the preceding chapters.

Limits of Cascade upwarp.-The limits of an upwarp are bere taken to be represented by those slopes produced by warping, by which the descent from the high, flat top to adjacent areas is accomplished, without regard to effects of erosion. 
In this sense the Cascade upwarp is limited on the north, according to the observations of G. O. Smith, apparently by a slope which extends across the axis of the range a short distance north of the forty-ninth parallel and leads down to a lower surface south of the Frazer River, but still high above the canyon of that stream. On the west, south of the forty-ninth parallel, according to Smith, the plateau of the upwarp extends, at an elevation of 5,000 feet, under Mount Baker, and thence descends to the Sound level by a monoclinal flexure. A degree of latitude farther south, northeast of Seattle, its western margin lies farther east. In the vicinity of Index, on the Great Northern, at the town of Snoqualmie, and along Green and White rivers, north of Mount Rainier, the descent from the mountain summits, at elevations of 6,000 to 7,000 feet, to that of the gravel plateau of the Puget Sound Basin is so abrupt as to suggest a fault scarp. There is no positive evidence of a fault as yet known, and the alternative hypothesis of glacial erosion has at least equal value at the present time. Beneath Mount Rainier and possibly to some distance west of that peak the upwarp maintains an altitude of 6,000 to 7,000 feet, and it appears in this latitude, just south of the forty-seventh parallel, to attain an' expansion comparable to that which it has along the forty-ninth parallel.

The eastern limit of the Cascade upwarp may in general be described as a slope which stretches in a direction south by west from the vicinity of Osoyoos Lake, on the forty-ninth parallel, to Ellensburg, and thence southerly along the west side of Yakima Valley, across the Columbia, into Oregon. This general statement of the position of the slope must, however, be qualified by the description of marginal flutings, which extend nearly at right angles to the major uplift far out into the adjacent plateau on the east and give to the axial upwarp an extremely irregular form.

The area of the upwarp thus described covers approximately 5 square degrees of the surface north of Columbia River, equivalent to about 20,000 square miles. Its further extent in Oregon has not been determined, but it is probable that it is equal to that in Washington.

MARGINAL, FLEXURES.

The eastern slope of the Cascade upwarp north of latitude $46^{\circ} 30^{\prime}$ has been studied physiographically by $G$. O. Smith and the writer with sufficient care to determine several marginal flexures, whose axes trend, in general, nortbwest and southeast; that is, nearly at right angles to the broad major axis of the upwarp itself. A statement of these features, so far as they may be described by the writer follows, with a brief account of the evidence according to which each is recognized.

Methow dononwarp.-Methow River is one of the larger tributaries of the Columbia, which it enters about midway between the Okanogan and the Chelan, in latitude $48^{\circ}$, longitude $120^{\circ}$. The general trend of the Methow Valley is south by 
east. Its headwaters are near the forty-ninth parallel, and are opposed to those of Paysayten River, which flow northerly. On the east is the Okanogan Range, and on the west the Methow, hoth of which are of great altitude. The elevation of the Methow above sea at its junction with the Columbia is 750 feet; at the town of Methow it is 1,158 feet, and at Winthrop, 30 miles from Methow, along the stream, it is 1,765 feet. Winthrop is situated at the principal forks of the river, aud above this point the grade of the strean rises more rapidly. The aspect of the valley at the present stream level varies, according to the rocks in which it is carved. A lower section, cut in schists, is narrow and canyon-like; an upper section. comprising most of the stretch between Methow and $W$ inthrop, is excavated in soiter Mesozoic rocks, and the valley floor is wider. It has been occupied by a glacier, which has left extensive deposits, especially along the river channel. From those conditions of diversity of rock structure and interaction of stream and ice work, it follows that the physiographic aspects of the valley are not simple, and that it presents a problem in sculpture which can be fully solved only by careful observation on the ground. That observation has not been had, and the inferences which follow are based upon distant views from the Methow Mountains, study of the Methow atlas sheet, and an interpretation consistent with that of phenomena of adjacent regions.

Above the valley bottom of Methow River, between Methow and Winthrop, many hills rise to an altitude of about 4,000 feet above sea, and they are thought to represent a former level, which theoretically may be that of the Methow Valley bottom reached during the Entiat stage or may represent the older Methow peneplain. If the former be the case, the corresponding level of the Methow plain would lie at an altitude above 4,000 feet, an amount which may be deduced from the depth of the Columbia Valley at the close of the Entiat stage. The maximum determined for that valley is about 2,100 feet, as observed in the Entiat Mountains: There is no reason to suppose that the Methow has made any deeper excavation than the Columbia. Indeed, the inference would be rather the other way. Hence the position of the Methow peneplain in the Methow Valley is not far from 6,000 feet above sea, provided the general uniformity of hilltops at 4,000 feet represents the bottom of the Methow Valley in Entiat time. On the other hand, the 4,000-foot level may stand for the Methow plain, and, if so, it would coincide by gradual slope with the general altitude of that plain in the Columbia River Plateau to the southeast.

Whether the level of the Methow peneplain in the Methow Valley be 6,000 or 4,000 feet above sea, it is lower than that of the plain on the adjacent Okanogan and Methow mountains, its place in the former being probably not far from 8,000 feet, and in the latter not less than 8,500 feet above sea. Hence it seems reasonable to regard the Methow Valley as a downwarp resulting from deformation of the Methow plain. 
Methon upworp. - Southwest of the Methow Valley, in latitude $48^{\circ}$, is a great mass of mountains known as the Methow Mountains. In it are sunk the canyons of the Twisp and Lake Chelan, and it extends westward into the highest part of the main Cascade Range. Its area may be estimated at 1,000 to 2,000 square miles, according to the limits which may be arbitrarily drawn between it and the central Cascade upwarp. This mountain mass is designated the Methow upwarp.

The Methow upwarp is defined not only by existing topographic features, but by the altitude of the Methow peneplain and the slopes which it has assumed. In general, where most elevated, the Methow plain has an altitude of 8,500 feet, coincident with the crest of the Methow Mountains. On the east the surface descends from Navarre Peaks to the Methow and Columbia, sloping from a probable altitude of 8,000 feet to that of 3,500 or less. Toward the northeast the surface slopes to the position of the plain in the Methow Valley: On the south the descent is from an altitude of 6,000 feet to that of 3,500 feet. The southern margin is complicated by a much smaller feature, the depression within which lies the lower end of Lake Chelan, and south of which is the uplift forming the Chelan Range. The upwarp of Chelan Mountains is, in fact, a spur of the Methow upwarp, with which it is continuous along Fourmile Ridge and across Lake Chelan at the Narrows, as shown in profile.

The rocks of this uplifted mass, so far as they have been observed by Russell and the writer, consist of ancient schist, together with intruded granite, quartzdiorite, and similar igneous rocks. They afford no structure significantly related to the present upwarp, unless it be vertical jointing. The cleavage which they exhibit is probably of much more ancient date. Considered in detail, there are marked differences in structure and texture, which constitute elements of heterogeneity; but considered in mass the whole is remarkably homogeneous. The northern and western portions of the upwarp do, it is true, include areas of Mesozoic sedimentary rocks; but they may be considered as incidental, rather than characteristic, since they are quite subordinate in area and volume.

The evidence of the Methow upwarp being thus limited to physiographic phenomena, it is found first in the altitude of the Methow plain, whose position has already been described. By reference to the sections on PI. XIX, it will be seen that it is essentially flat-topped and connected by gentle slopes with the position of the plain on three sides. Further evidence is found in the effects of corrasion, especially as exemplified in the canyons of Twisp and Chelan rivers, which are among the most profound and most sharply cut of the entire Cascade Range. That of the Twisp heads near the junction of the Methow uplift with the main Cascades, where the elevation of the flat surface is about 8,500 feet, and descends rapidly to its junction with the Methow at 1,600 feet. The greater part of this descent of 7,000 
feet is made in the first 10 miles, and the canyon thence to its mouth is flat-bottomed. It is clearly the product of retrogressive activity of the stream working headwards against the slope of the upraised mass west of Methow River. The upper course of the stream is along the axis of the uplift, and there is a sharp bend by which the river turns, as it were, down the slope. toward the Methow. It is possible that this change of direction is significant of an episode of capture in the history of the Twisp, which may formerly have flowed on in a continuous southeasterly course toward Libbey Creek; but no adequate study of the topographic forms has been made to determine that such was the fact. The development of the Chelan Canyon has already been described, and it has been shown that the relations between its several parts and to the old channels of Knapp and Navarre creeks are best explained as results of the opportunities for piracy which were provided by the growth of the Methow upwarp. The open valley of lower Lake Chelan is inconsistent in topographic phase with the great canyon above Twentyfive Mile Creek, and the inconsistency is regarded as evidence of the vigorous elevation from which the youth of the latter section follows. The mature aspect of topographic forms about the lower section of Lake Chelan, and the beheaded character of Knapp and Navarre coulees, are facts which show that the Lower Chelan region was relatively depressed as the Methow upwarp rose.

Chelan Butte upwarp. - South of Lake Chelan, and between it and the westwardtrending course of Columbia River, is the striking eminence of Chelan Butte, having an altitude of 3,892 feet. The summit of granite dikes and schist is considered to be a monadnock, rising perhaps 400 feet above the Cascade plain. Thence westward extends a ridge having an elevation of 3,000 to 3,500 feet, which rises to the summit of Baldy Mountains, 6,432 feet, and continues northwestward in the Chelan Mountains, of which the culminating summit is Stormy Mountain, 7,219 feet. The heights of Baldy, Stormy, and other acute peaks which are largely maintained by outcrops of quartz diorite, are believed also to represent monadnocks above the Methow plain, the altitude of which is somewhat above 6,000 feet. South of this elevated ridge the Methow plain is recognized in the Waterville plateau at an elevation of 2,800 to 3,000 feet, that is at least 500 feet below its probable position on Chelan Butte, and is noted in Ribbon Mesa and in the hill rising to an altitude of 3,757 feet at 3,000 to 3,500 feet, or about 3,000 feet below its position about Stormy and Baldy mountains. 'This difference in altitude of the Methow plain is taken as representing the slope from the axis of an upwarp which corresponds with the trend of the Chelan Mountains from Stormy east by south to Chelan Butte, and which divides the basin of the Lower Chelan from that of the Waterville plateau. The peculiar physiographic relations of Knapp and Navarre coulees are interpreted as effects of this upwarp, across which the streams held their respective courses until. 
they had cut deep canyons, but by which they were ultimately retarded until they were beheaded by the Little Cholan, a tributary of the Columbia north of the axis.

Waterville downwarp.-The Methow plain is very clearly preserved in the Waterville plateau and Ribbon Mesa, the latter lying west of Columbia River at a general altitude of 2,800 to 3,000 feet. The Methow plain is lowest, so far as observed, where it is represented in two small mesas southeast of Waterville, at an elevation of 2,800 feet, and from this least altitude it rises northward, westward, and southward as would the surface of a shallow spoon. This depression, which is recognized solely on the evidence of the deformed Methow plain, is an embayment between the Chelan Butte upwarp and that of Badger Mountain, and, like the basin of lower Lake Chelan, is a minor crenulation of the margin of the Cascade upwarp.

Badger Mountain uplift.-Badger Mountain, cast of the Columbia, has already been described as a broad, low elevation of the Columbia Plateau. West of the river its axial continuation is the Entiat Mountains, which, extending northwestward, lie between the headwaters of Entiat and Wenatchee rivers. This line of mountains, although divided by the canyon of the Columbia, is a continuous zone of uplift, highest toward the northwest, and sinking sontheastward into the level of the central plateau of Washington. Along this summit the Methow peneplain is recognized in Badger Mountain at an altitude slightly above 4,000 feet; in the eastern end of the Entiat Range at 4,800 to 5,000 feet; 10 miles farther northwest, about Cougar Mountain, at 6,000 feet; and near the headwaters of the Entiat at probably 6,500 feet. These are maximum elevations, from which the plain slopes away to the northeast down to the Waterville plateau and Ribbon Mesa, already described, and to the southwest into the valley of the Wenatchee. Adjacent to the Wenatchee Canyon its probable altitude is not far from 4,000 feet. On the evidence of the relative altitudes of the old plain, the Badger-Entiat axis is recognized as a zone of local uplift. This inference is sustained by an examination of the canyon of the Columbia, and its relation to the Columbia Valley of the Entiat cycle, as appears from a comparison of the depth of the canyon abreast of Badger Mountain with that below Chelan Butte, and the relative altitudes of the old valley floor in the corresponding positions. The fall of the Columbia at the present time from Chelan Butte to Wenatchee, a distance of 25 miles, is about 15 feet, and may therefore be left out of consideration, the river being taken as a level datum. The depth of the canyon below the older valley at Chelan Butte is 800 feet, and abreast of Badger Mountain is 2,000 feet; that is to say, the old valley floor is 1,200 feet higher above the practically level river bed 25 miles farther downstream. As the river can not be supposed to have flowed up this slope, it is evident that the valley floor has been raised 1,200 feet more at the Badger Mountain axis than it has south of Chelan Butte. This relation demonstrates the ability of the antecedent Columbia River to maintain its course across the rising uplift. 
Wenatchee downwarp and upwarp.-The Wenatchee Valley, like the Methow, is floored in pait by sedimentary rocks which are more easily eroded than the schist and granite and basalt of adjacent districts; and as it has been deeply eroded by both ice and water, its physiographic features are complex. It is inferred that it corresponds to a downwarp having the form defined by the contours, and that it is limited on the southwest by the Wenatchee upwarp. The broad, evenly sloping surface of the latter is thought to represent very closely the Methow plain.

\section{EPISODES OF DEFORMATION.}

PRE-TERTIARY DEFORMATION.

The latest effects of deformation, those which have been described and which are of late Tertiary and post-Tertiary date, are but the most recent of a number of movements whose history within the Cascade province no doubt goes back to the earliest geologic events that can there be recognized. It would not fall within the scope of this article to discuss pre-Tertiary movements, even were adequate data available, but it is desirable to point out that each of the major downwarps of post-Tertiary time corresponds in position with a synclinorium in which pre-Tertiary sediments were deposited. Cretaceous strata occur in the Methow downwarp, and Eocene deposits are extensively developed in the Wenatchee and Yakima downwarps, whereas on the intervening upwarps the rocks are very much older. With regard to the Cretaceous, we can not say that the limits of geographic distribution of the sediments correspond with the depression which developed later. Indeed, the Cretaceous rocks extend across the northern part of the Cascade upwarp, where they occur upturned to dips of 90 degrees. The basins of Eocene strata, on the other hand, were of local character, and apparently do correspond somewhat closely to the respective downwarps in which they are found; but this is not true, as pointed out by G. O. Smith, in regard to the Miocene of the Yakima Valley. Rocks of Miocene, Eocene, Cretaceous, and earlier ages had suffered compressive stress and been folded during more than one expoch of deformation before the beginning of that late Tertiary topographic cycle during which the Methow peneplain developed.

From these facts it is apparent that the post-Tertiary deformation was not a peculiar effect initiated in a region previously little disturbed, but was merely the successor of other effects to which it may be genetically related, in so far as a common cause may have acted in this province from an early geologic date.

This is an expression of a fact.which is of general occurrence so far as the writer's observation goes, namely, that a region of orogenic movement has commonly been the scene of repeated mountain growths widely separated in time. The reverse (that there are extensive provinces in which mountainous elevations have not developed) is also true, and the facts thus point to persistence, intermittence, and localization of the causes of orogeny. 
TERTIARY AND POST-IERTIARY DEFORMATION.

All that follows relates to deformation which is later in time of occurrence than the planation of the Methow pencplain. The effects as a whole might be summed up in the phrase the growth of the Cascade Range. The general effect is the uplift of the mass from which the Cascade Mountains are carved, and the details have been described in preceding paragraphs.

Through a study of the physiography, and particularly of the Columbia River Valley above Wenatchee, two episodes of deformation bave been distinguished, the first being that which occasioned the Entiat cycle of physiographic development, the second that which gave rise to the Twisp cycle. Referring to the table of physiographic development, it will be seen that these may both be considered pre-Glacialthat is, pre-Pleistocene-if the glacial conditions of the Cascade Range be found to have been restricted to a single episode; or the Entiat and Twisp cycles may both fall within the Pleistocene if two or more glacial episodes should be recognized: The writer inclines to the belief that the latter interpretation is correct, the reasons being that the condition of planation reached during the Methow cycle was probably such as to require most of Pliocene time for its development, and, further, that there is distinct evidence in the drift deposits of Puget Sound of two well-separated glacial invasions. Thus it seems probable that both episodes of growth of the Cascade Range fall within the Pleistocene division of the Quaternary.

It has been pointed out by G. O. Smith that effects of apwarping and downwarping, which in the Yakima Valley may be regarded as effects of Twisp date, correspond to anticlines and synclines that developed before the Methow plain reached its last phase. Smith does not in his area recognize the Fntiat stage, and no comparison of effects of that stage with others is made by him. In the region north of the Wenatchec, however, it seems probable that upwarps and downwarps which were moderately developed during the Entiat cycle were greatly accentuated during the Twisp cycle, and that there was practical coincidence of the axes of elcvation and depression during the two different episodes. Thus the Columbia Valley across the Entiat-Badger Mountain upwarp is deeper for each of the two cycles than the corresponding valley south of Chelan Butte, and it follows from this fact that the axis of upwarping was well marked in the earlier as well as in the later stage of deformation. Many of the facts of physiographic development which have already been adequately discussed point in the same direction.

\section{CAUSES OF DEFORMATION.}

DIRECTION OF STRESS.

Granting that theoretically stress may be exerted in the earth's crust from any direction, it is convenient to discuss effects of stress as due to vertical or horizontal 
components, which are thus taken as being those forces that have given rise to deformation; and in what follows there is a tacit assumption that we have to deal in this particular case with effects either of vertical stress or of horizontal stress, one or the other and not both.

Vertical stresses appear at first sight more probably to have been the effective causes of vertical uplift than horizontal stresses, and the imagination appeals to the intrusion of deep-seated batholiths of granite beneath the elevated mass of the Cascade Range. In doing so it can point to pre-Eocene and Miocene intrusions of granite within the area; it may emphasize the fact that the principal:monadnocks above the Methow plain are of granite Mount Stuart .being the most striking and important example, and from the soccurrence of granite within the areas of upwarps it may argue a coincidence of intrusion with uplift: The: last-named point is, however, in a measure invalidated by the fact that the occurrence of granite beneath the later sediments which lie in the downwarps can neither be affirmed nor denied. Against the hypothesis that the deformation of the Cascade Range is due to vertical stress, and possibly to batholithic intrusion, are the generally observed facts that the rocks everywhere exhibit phenomena of jointing and flexure due to compression and that folds in the bedded basalts of the Yakima Valley are even overturned.

Turning to consider the effects of tangential or horizontal compressive stress, it is desirable to distinguish two classes of effects, one of which may be known as competent structure, the other as incompetent structure, involving shear or flow. Competent structure is exhibited in an elevation of stratified rocks such as is commonly described by the term anticline. It is developed under conditions that direct the effective component of the stress in the direction of bedding. At any. point of change of dip the stress is resolved into two components, one of which continues in the farther direction of bedding, and the other acts radially to elevate the stratum with the load resting upon it. The requirements of development of the structure are those of an arch capable of supporting the superincumbent load; and the proportions of the structure are limited accordingly. From these considerations it follows that anticlines raised under the law of competent structure are relatively narrow. ${ }^{\text {" }}$

The horizontal extent of the Cascade uplift is so great as compared with its height that if regarded as an arched structure it is exceedingly flat. Its width varies from forty to sixty times its height; and it is clear that no section of a body of rocks thus extending over two or three scores of miles can be looked upon as self-sustaining. It follows that the elevation of the range as a competent structure can not be considered.

The development of incompetent structure by compression results in shortening the mass in one direction, or in two directions; with corresponding elongation of the

aWillis, Mechanics of Appalachian structure: Thirteenth Ann. Rept. U. S. Geol. Survey, pt, 2; Van Hise, Principles of pre-Cambrian geology: Sixteenth Ann. Rept. U. S. Geol. Survey, pt. 1. 
other dimensions, or of the third dimension. The change of volume, if there be any, is assumed to be negligible; that is, in considering this type of deformation the volume is taken to be constant. The strain may be that which is described by Becker

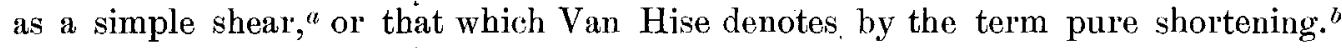
The distinction lies in the internal structures developed within the mass, the change of form as a whole being the same in either case.

It has been shown by Becker, through mathematical analysis, ${ }^{c}$ that dividing: planes develop through simple shear in elastic brittle masses at angles approaching 45 degrees to the direction of stress, and this theoretical conclusion has been abundantly substantiated through experiment. On the other hand, Van Hise and Hoskins have shown that in case a rock mass has been made to flow in a direction of least resistance, cleavage planes are developed in a normal attitude to the direction of stress. The structural change is apparently one involving minute movements upon many parallel planes, accompanied by the rotation of already existing mineral particles and the development of new minerals whose longest axes are parallel to the direction of flow. This structure develops only in the zone of flow and gives rise to "flow cleavage." Shear, as described by Becker, may occur in any rigid mass, in the zone of flow or in that of fracture; in the zone of flow it does not correspond with flow cleavage; in the zone of fracture it may give rise to independent "fracture cleavage" or jointing.

The structural phenomena of the Cascade Range are illustrated in the two views of Pl. XX, which were both taken within a mile of Cascade Pass at the head of the Stehekin. In $A$ the cliff rising above the lake exhibits near the center of the view a number of inclined joint planes, which are sufficiently well marked to have determined the courses of the rivulets descending from the slope above. No exact observations of the dips of these planes are available, but they appear to lie at such an angle to the horizontal as possibly to come within the limits assignable to the attitude of shearing planes or fracture planes. They may be hypothetically regarded as effects of shear developed in the zone of fracture through a horizontal compressive stress. In Pl. XX, $B$, a nearly vertical cleavage structure is clearly exhibited in the details of topographic forms. It is that structure which if dominant in the heart of the Cascade uplift, and so far as macroscopic examination shows it has the characteristics assigned by. Van Hisento cleavage developed in the deep zone of flow. The inference which may, with some assurance, be drawn from its widespread occurrence is that the mass of the Cascades was deformed while that portion now exposed in the highest peaks was still very deeply buried. ${ }^{d}$

\footnotetext{
a Finite homogeneous strain, flow, and rupture of rocks: Bull. Geol, Soc. America, vol, 4, p. 22.

$b$ Principles of North American pre-Cumbrian geology: Sixteenth Ann. Rept. U. S. Geol. Survey, pt. 1, p. 636

c Ibid., p. 30 et seq.

dFor related observations see Spurr, J. E., Ore deposits of Monte Cristo, Washington: Twenty-second Ann. Rept. U. S. Geol. Survey, pt. 2, pp. 801-802.
} 


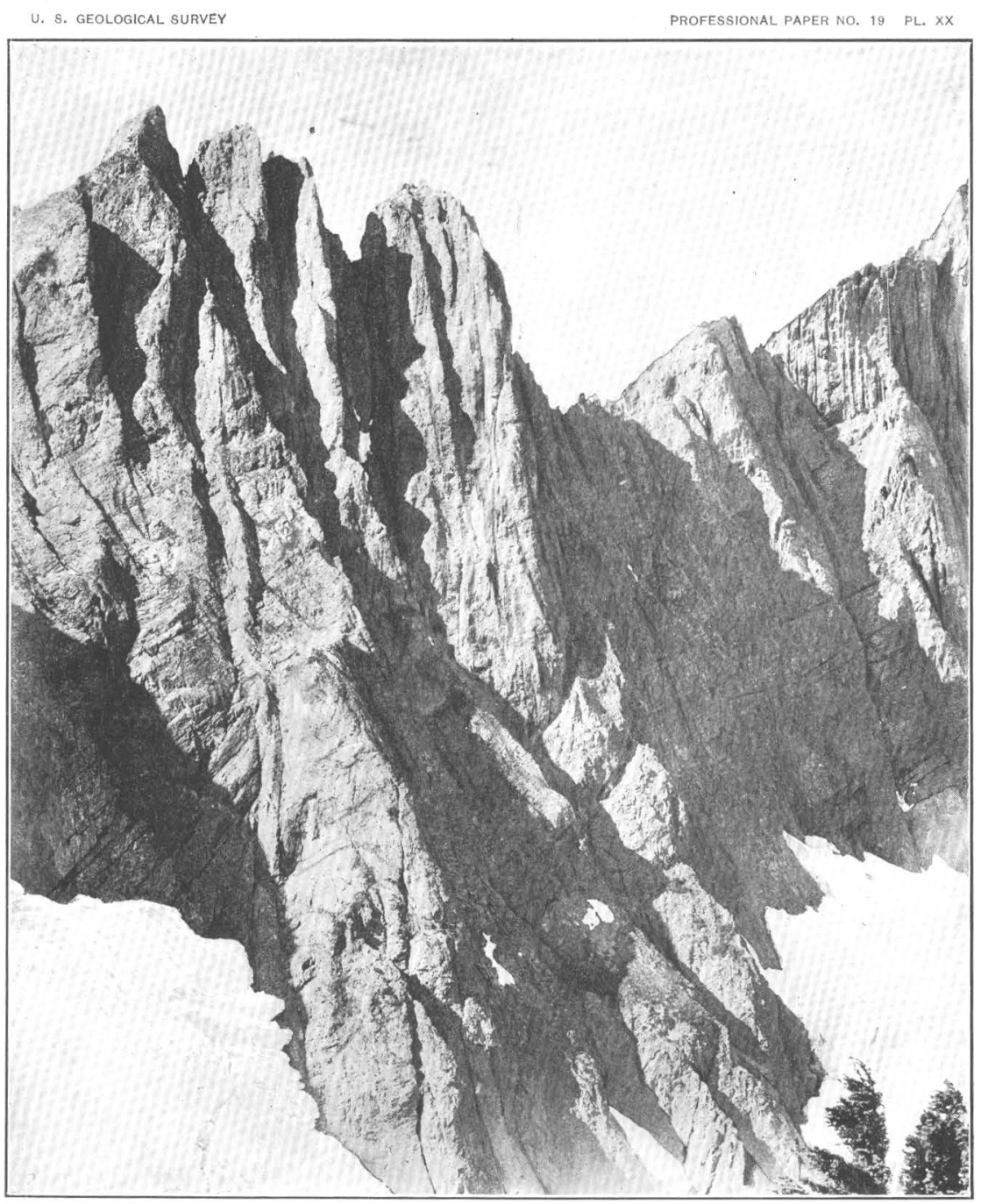

A. SOUTHERN SLOPE OF BOSTON MOUNTAIN, SHOWING INCLINED JOINT PLANES.

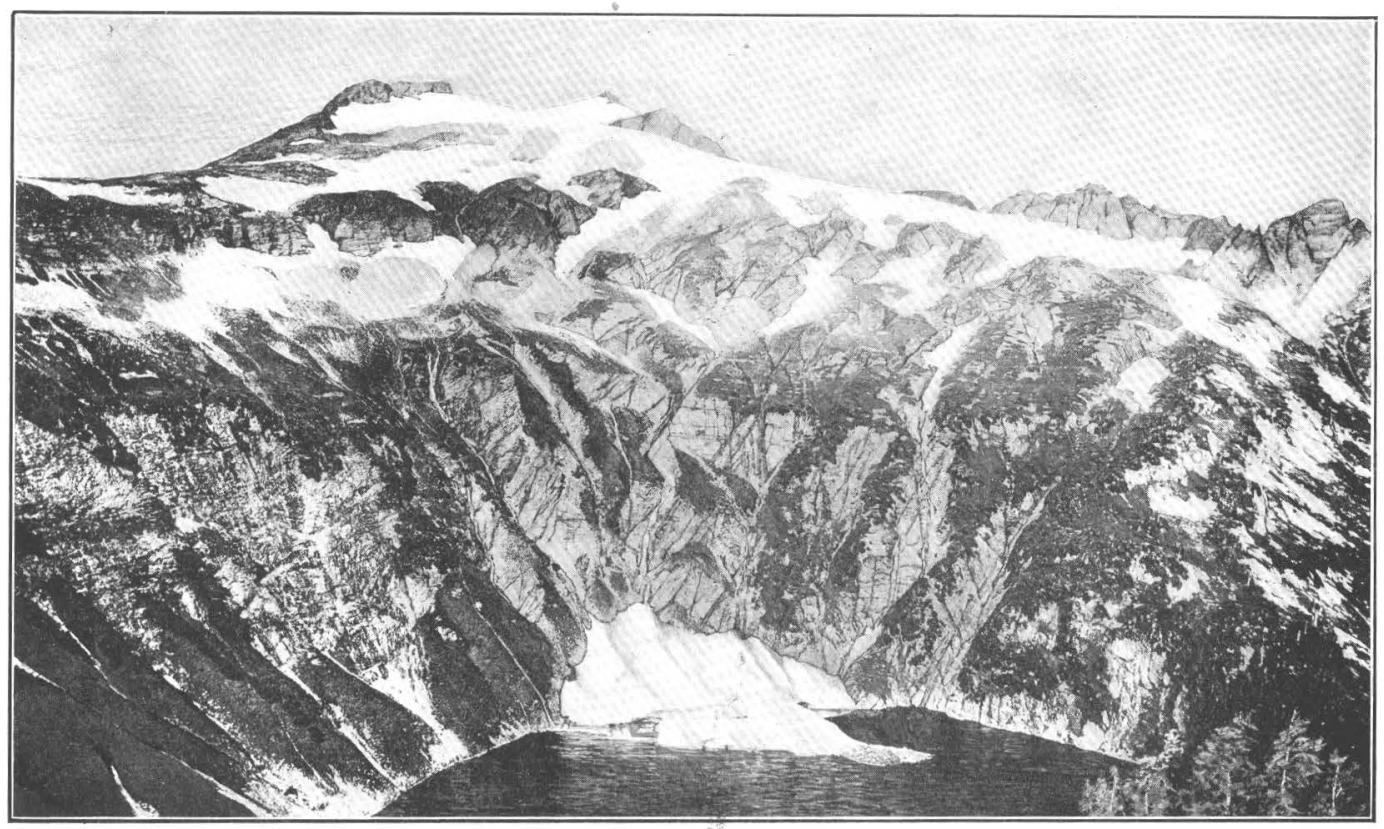

B. PINNACLES SOUTHWEST OF CASCADE PASS, SHOWING VERTICAL JOINTING. 
Flow cleavage and fracture cleavage structure have a common origin in compressive stress. The observed structures in the Cascade Range occur generally throughout the mountains, and can not be separated according to locality. They may perhaps be distinguished by date. If it should be found that the fracture cleavage developed in the zone of flow cleavage, the two may be assigned to a common episode of deformation, the date of which must be set so far back that the cleaved rocks were exposed through erosion before the development of the Methow plain; that is to say, to a pre-Pliocene date. On the other hand, it may be that the fracture cleavage or jointing was predominantly developed in the zone of fracture, and must be assigned to a date at which the rocks that it now traverses were nearer the surface than they had been when the flow cleavages were formed. In this case the relation of the inclined jointing to the pre-Pliocene cleavage may be such that the shearing can be attributed to that compressive stress which is thought to have caused the elevation of the Cascade mass as it is now observed. This is the conclusion reached by Spurr. ${ }^{a}$

DIMENSIONS OF THE CASCADE BIOCK.

The speculations of the preceding paragraph in regard to the depth at which the structures may have developed naturally lead to consideration of a problem which may be stated thus: What may have been the depth of the prism which in consequence of compression horizontally was so elongated vertically as to produce the Cascade uplift. There are many qualifying factors, the data for which are incomplete or wanting; numerical results, therefore, can at best indicate only an order of magnitude, yet nevertheless there may be profit in stating the conditions of solution.

Stripped to its purely mathematical form the problem is: Given a prism, supported in isostatic equilibrium and subjected to strains in consequence of which its width, length, and height are changed, but without change of volume; and given the width before and after strain, the ratio of lengths before and after strain, and the amount of vertical elongation, to calculate the original height.

Through the courtesy of Mr. George F. Becker the following mathematical analysis is given:

$$
\text { UPLIFT BY HORIZONTAL COMPRESSION. }
$$

The original dimensions of a block are $\mathrm{x}, \mathrm{y}, \mathrm{z}$, where $\mathrm{y}$ is vertical.

As a result of strain the dimensions become $x^{\prime}, y^{\prime}, z^{\prime}$, and the volume remains constant.

Let $\mathrm{x}^{\prime}=\alpha \mathrm{x}$ and $\mathrm{z}^{\prime}=\beta \mathrm{z}$, then $\mathrm{y}^{\prime}=\frac{\mathrm{y}}{\alpha \beta}$. 
In a given case suppose that we know

Then,

$$
\frac{\mathrm{x}^{\prime}}{\mathrm{x}}=\alpha, \text { and } \mathrm{y}^{\prime}-\mathrm{y}=\mathrm{b}
$$

So that

$$
y^{\prime}-y=y^{\prime}-\alpha \beta y^{\prime}=y^{\prime}(1-\alpha \beta) ;
$$

$$
y^{\prime}=\frac{b}{1-\alpha \beta} \text {. . . . . . . . . . . }
$$

Here $y^{\prime}$ may be estimated on various hypotheses:

A. If $\beta=1$, or if there is no strain in the direction of $z,(1)$ gives

$$
y^{\prime}=\frac{b}{1-\alpha} \text {. . . . . . . . . . . }
$$

B. If the strain is the same in the directions $x$ and $z,(1)$ gives

$$
y^{\prime}=\frac{b}{1-\alpha^{2}} \text {. . . . . . . . . . . }
$$

C. If the strain is the same in the directions $y$ and $z$,

$$
\begin{aligned}
& \frac{1}{\alpha \beta}=\beta \text {, so that } \beta=\frac{1}{\sqrt{\alpha}} \text { and (1) becomes } \\
& \qquad y^{\prime}=\frac{b}{1-\sqrt{\alpha}} \text {. . . . . . . . . . . . . . }
\end{aligned}
$$

To apply this general formula to the special case of the Cascade uplift we may approximate to $\mathrm{x}$, the original width, on the warped surface of the peneplain; may

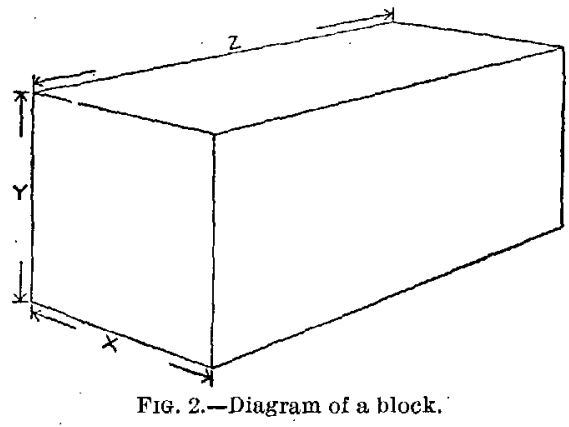
measure $x^{\prime}$, the present width, as the distance from the western to the eastern base of the uplift at sea level; and may determine the amount of vertical elongation as the mean elevation of the warped surface above sea level.

The complete form of the upwarped surface not having been worked out, it appears best to express, between rather wide limits, the relations of the width $\mathrm{x}$ before strain to the present width $x^{\prime}$. According to an estimate based on measurements of the warped surface from Columbia River over the Methow Mountains, the width on the warped surface must exceed that on the sea-level line by more than onetenth of a mile in a hundred miles, and this may be taken as the least possible ratio of $\mathrm{x}$ to $\mathrm{x}^{\prime}$. Whereas, on the other band, this ratio probably does not exceed 2 miles in 100 , since the width on the warped surface is an arc $\mathrm{A} \mathrm{C} \mathrm{B}$ and is considerably shorter than the distance A D E B, which, if the mean height be $1 \frac{1}{2}$ miles, is 3 miles. The altitude of the Cascade upwarp being about 8,500 feet over $a$ large area, a mean height of $1 \frac{1}{2}$ miles is probably a reasonable estimate. In latitude 
$47^{\circ} 30^{\prime}$ the present width of the uplift on a sea-level line is close to 100 miles. Thus, to obtain a preliminary approximation to the possible limits of the depth of the strained mass we may introduce into the equations: $x=100.1$ and $102 ; x^{\prime}=100$; $\mathrm{b}=1.5$, all values being miles.

Table of estimated depths of strained mass of the Cascade uplift, calculated and arranged to show the probable limits according to the three equations, which express different conditions of strain.

\begin{tabular}{|c|c|c|c|c|c|c|}
\hline & \multicolumn{6}{|c|}{ Values of $y^{\prime}$ in miles. } \\
\hline \multirow[t]{3}{*}{. } & $A$ & & B & & & . \\
\hline & $y^{\prime}=\frac{b}{I-\alpha}$ & & $==\frac{b}{1-\alpha^{2}}$ & & $y^{\prime}=\frac{b}{1-1}$ & \\
\hline & $x=100.1$ & $x=102$ & $\mathrm{x}=100.1$ & $x=102$ & $x=100.1$ & $x=102$ \\
\hline$y^{\prime}=$ & 1,500 & 75 & 750 & 37.5 & 15,000 & 150 \\
\hline
\end{tabular}

- The results under $C$ may be discarded, since the equation $y^{\prime}=\frac{b}{1-\sqrt{ } \alpha}$ is based on the assumption that the elongation is the same in the directions of $y$ and $z$; but $z$ is a horizontal dimension at right angles to $x$, and the observed facts of deformation show not only that there has not been elongation of $z$; on the contrary, there has been shortening. The shortening in the direction of $z$ is less than that in the direction of $\mathrm{x}$, however, and therefore equation $\mathrm{B}$ does not exactly apply; but the strain is expressed by the general equation $y^{\prime}=\frac{b}{1-\alpha \bar{B}}$, in which $\mathrm{B}$ is less than $\alpha$ and greater than 1. If all the assumptions be valid, and if they cover the conditions of strain, the depth of the strained mass should lie between the extremes of B and A-that is, it should be more than 37.5 miles and less than 1,500 miles.

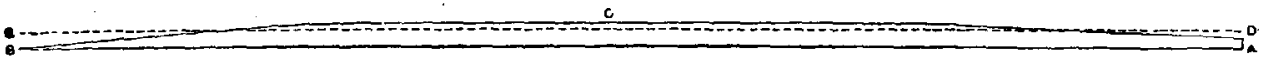

Fra. 3.-Diagrammatic section of a deformed mass.

If these limits appear to be so far apart as to leave the estimate little value, the writer would point out that the least depth indicated carries the base of the prism down into the zone of rock flow, below that superficial film in.which the strength of rocks, as we know it, is a factor in transmitting stresses sufficient to cause orogenic movement. The inference is that a cause of the Cascade uplift (and presumably of related quaquaversals) is to be found in compressive stress acting on materials below the outer crust; the superficial movements, both vertical and horizontal, may then be incidental results of deep-seated strains.

14493--No. $19-03-7$ 



\section{INDEX.}

\begin{tabular}{|c|c|}
\hline Page. & ge. \\
\hline Agnes Creck, topography of region near ............ & Chelan Basin, drainage of. \\
\hline Andesite, occurrence of ......... & glaciation in. \\
\hline A rid areas, Entiat features in $\ldots \ldots \ldots \ldots \ldots \ldots \ldots \ldots$ & rocks of \\
\hline adger Mountain, a residual of the Methow plain .... & Chelan Brook, location and drainage area of.......... \\
\hline 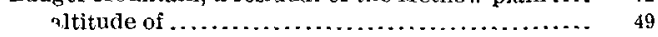 & 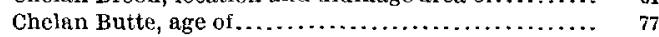 \\
\hline 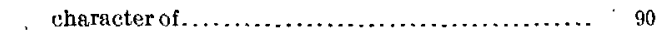 & height of.$\ldots \ldots \ldots \ldots \ldots \ldots \ldots \ldots \ldots \ldots \ldots \ldots$ \\
\hline location and general features of $\ldots \ldots \ldots \ldots 51,52-53,79-80$ & physiography of \\
\hline Badger Mountain uplift, description of .............. 90 & view of, plate showing ................. \\
\hline Baker, Mount, Cascade platenu near . . . . . . . . . . . . & views from, plates showing ............. \\
\hline Baldy Mountain, height of ........ & Chelan Butte upwarp, description of . \\
\hline rocks and topogra & Chelan Falls, glaciation near...... \\
\hline Basalt, occurrence and character of.... $11,12,15-17,50,64,84$ & Chelan, Lake, basin of, depth of, theories to explain.. $82-83$ \\
\hline Becker, G. F., cited on deformation............... 94 & basin of, features of $\ldots \ldots \ldots \ldots \ldots \ldots \ldots \ldots \ldots$ \\
\hline mathematical arolysis applicable to Cascade & nd geologic his \\
\hline uplift furnished by $\ldots \ldots \ldots \ldots \ldots \ldots \ldots \ldots$ & divide between $\mathbf{L}$ \\
\hline Boston Mountain, view of, plate showing ............ 94 & drift dam at ..... \\
\hline Calkins, Frank C., aid rendered by.. & elevation and depth of $\ldots \ldots \ldots \ldots . . . .$. \\
\hline Campbell, M. R., references to ................... 35,47 & geologic features of region near ........... \\
\hline ion of. & 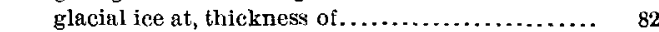 \\
\hline$\ldots \ldots \ldots \ldots \ldots \ldots 26-28$ & near .............. \\
\hline 28 & physiographic features of Columbia gorge corre- \\
\hline identification of ............. 24-26,27-28 & 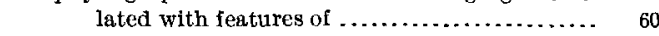 \\
\hline ains, canyons in, features of .......... 81 & Narrows of, location of $\ldots \ldots \ldots \ldots \ldots \ldots \ldots$ \\
\hline .................. & Narrows of, plate showing.... \\
\hline elevation of, lack of uniformity in, cause of...... & rocks near $\ldots \ldots \ldots \ldots \ldots \ldots \ldots \ldots \ldots$ \\
\hline physiographic problems in, stream evidence bear- & views of, plates showing..... \\
\hline 32 & Chelan Lake Basin, lower part of, physiographic his- \\
\hline Cascade Pass, views near, plates showing . ......... 54,94 & 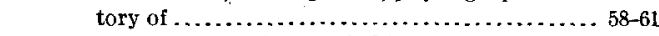 \\
\hline thesis of $\ldots \ldots \ldots \ldots \ldots \ldots \ldots, \quad 12$ & aic bistory of $\ldots \ldots \ldots \ldots 61-63$ \\
\hline$\ldots \ldots \ldots \ldots \ldots \ldots \ldots \ldots$ & district, drainage of .. \\
\hline$n \ldots \ldots \ldots \ldots \ldots \ldots \ldots, 32$ & Chelan Mountains, physiography of ............... 65-66 \\
\hline$\cdots$ & Chelan quadrangle, northern half of, physiographic \\
\hline 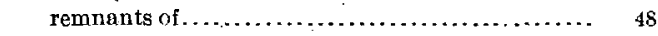 & 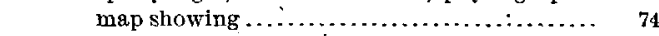 \\
\hline character of $\ldots \ldots \ldots \ldots \ldots \ldots \ldots \ldots .29-30$ & to showing.. \\
\hline ascade Runge, age of . & position of ......... \\
\hline 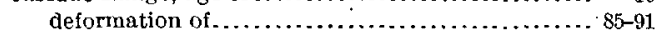 & ical events of................ \\
\hline tions of $\ldots \ldots \ldots \ldots \ldots \ldots \ldots \ldots$ & (2...................... \\
\hline (n........................... & of $\ldots \ldots \ldots \ldots \ldots \ldots \ldots \ldots$ \\
\hline . & 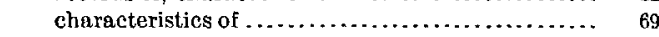 \\
\hline development of, table showing .... & Chelan-Stehekin drainage system, glaciers of..... \\
\hline$\ldots \ldots \ldots \ldots \ldots \ldots \ldots \ldots .10-11$ & urce and course of ... \\
\hline summit level of, uniformity of .................. & slide topography of ..... \\
\hline summits of, views of $\ldots \ldots \ldots \ldots \ldots \ldots \ldots \ldots \ldots, 74-75$ & Clealum Ridg \\
\hline cedent drainage in, identification of. & 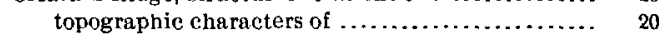 \\
\hline uplift of central portion, eharacter of $\ldots \ldots \ldots \ldots \ldots .34-35$ & 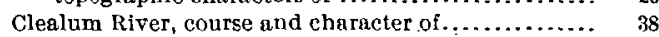 \\
\hline$\ldots \ldots \ldots \ldots \ldots 50,54,66,94$ & phy at head of ................ \\
\hline atures of $\ldots \ldots \ldots \ldots \ldots \ldots \ldots \ldots \ldots \ldots \ldots+74-75$ & Columbia River, elevation of .................. \\
\hline seade uplift, height of $\ldots \ldots \ldots \ldots \ldots \ldots \ldots \ldots \ldots \ldots$ & 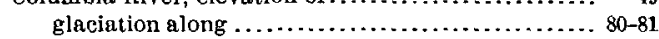 \\
\hline$\ldots 85-86,93$ & $\ldots \ldots \ldots \ldots \ldots \ldots \ldots \ldots, 49-51$ \\
\hline$\ldots \ldots \ldots \ldots \ldots \ldots \ldots \ldots \ldots .886-91$ & gorge of, features of, correlated with those of Lake \\
\hline 1 ............... & \\
\hline ted depths of... & in in \\
\hline
\end{tabular}


Columbia River, peaks near................... $49-50$ plateau marked by :....................... 51 tributaries of, topographic and other features of .. 53-63

Columbia River Canyon, history of .............. 80-81 physiography of ........................... 49-50 walls of, recession of $\ldots \ldots \ldots \ldots \ldots \ldots \ldots \ldots \ldots . . .61$ Columbia River lava, description and history of..... 11-13 Columbia Valley, twofold character of .............. $\quad 76$ view of, plate showing .................... 64 Cooper Mountain, character of ................... 75

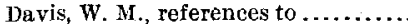

Dawson, G. M., reference to .................... 74

Deformation, causes of . ...................... 92-97 diagrams illustrating ....................... 96,97

discussion of . . . . . . . . . . . . . . . . . . . . . . . . . $88-97$ episodes of . . ................................. $91-92$ fundamental propositions concerning ........... 84 post-Tertiary, evidence of....................... 92 pre-Tertiary, evidence of . Tertiary, evidence of .

Easton sehist, age, charneter, and occurrence of ...... Ellensburg formation, age, character, and thickness of - 17-18

Ellensburg quad rangle, area, location, and features of . basalt interbedded with sandstone in ............ geologic map of portion of.

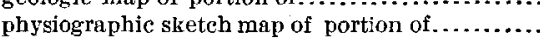
structural features of

Ellensburg sandstone and Yakima basalt, contact of figure showing.

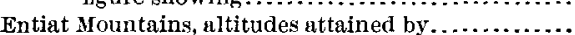
physiography of

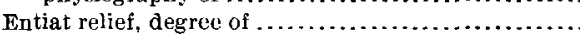

Entiat River, description and history of............ 55-56

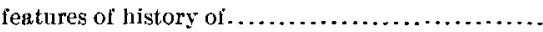
old channel of . .

Entiat slope, line of demarcation between Twisp slope and

Ential stage, age of features of, in arid areas. ..................... 79-80 first recognition of............................ 76 glaciated remnants of .......................... 78 physiographic relations of .................. $75-76$ position and form of ...................... 68,75 residuals of, distribution and character of $1 . \ldots .76-80$ topogmaphy of, maturity of ................. 78-79

Entiat Valley, physiography of ................. $55-56$

Eocene rocks, folds in ........................ 20 occurrence and character of................. 15-16 thickness of .................................

Farmer, R. A., reference to work of .............. 49 Fourmile Ridge, Chelan Mountains, age of formation of :

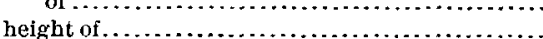

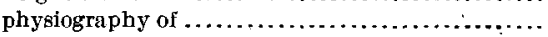
rocks of .

Geologie history, summary of

Geologie structure, features of ...................... $19-21$

65

Gilbert, G. K., references to ................... 34, 35,47

Glacial ice, thickness of, at Lake Chelan............. 82

thickness of, at Safety Harbor Creek ..............

Glaciers of Chelan-Stehekin system, former extent of. $82-83$

Gold Creek, view from head of, plate showing ........

Granite, occurrence of.

Granite-porphyry, occurrence of ....

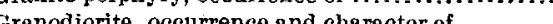

Griswold, W. T., reference to work of ...............

Hawkins formation, age and character of.
Hayes, C. W., reference to........................ Page.

Hornblende-gneiss, occurrence of ................

Hoskins, L. M., cited on rock flowage .............. 9

Hypersthene-andesite, occurrence of.............. 18

Icicle River, character of ..........................

. Igneous rocks, occurronce and character of .......... 14-15

Kittitas Valley, features of ..................... 24-25

Knapp Coulee, features of ................... 56-57,61

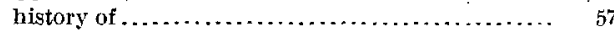

Knapp Creek, diversion of, by deformation ............ 61 drainage area of ............................ 6

Knowlton, F. H., determinations of tossil plants by ... 17,47 Iake Creek, divide between Lake Chelan and, height of ................................. $62-63$

Landslides, occurrence of...................... 23,51

Lava, basaltic, occurrence of ..................... 50

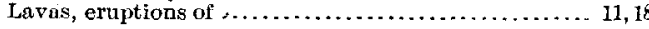

Manastash formation, occurrence and character of ... 16

Mascall formation, correlation of................. 17-18

Methow downwarp, description of ............... 86-87

Methow Mountains, area of.......................

character and position of .................. 59

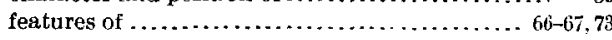

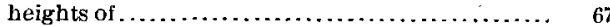

Iocation of ............................. 66

profiles of, west of Navarre Peaks............. 75

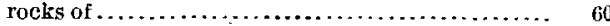

topography of ............................ 78

Methow peneplain, altitude of ............... 87, 90

Methow plain, altitude of .................. 87,89-90

probable origin of $\ldots \ldots \ldots \ldots \ldots \ldots \ldots \ldots \ldots \ldots, 70-71$

residuals of, distribution and character of ....... $72-75$

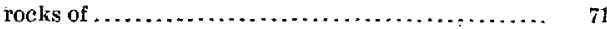

topography of.......................... $\pi 1-72$

Methow quadrangle, southern half of, physiographic

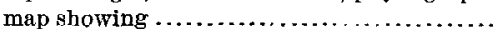

Methow River, course, elevation, and grade of . ...... 87 glacial deposits along. ....................... $\quad 87$

Methow stage, age of ........................... 69,70

characteristic feature of ..................... 70

conditions of development of................. $70-75$

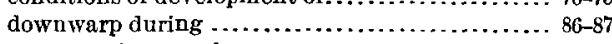

topographic type of $\ldots \ldots \ldots \ldots \ldots \ldots \ldots \ldots \ldots \ldots \ldots . .68$

upwarp during . ............................ 88-89

Methow Valley, glacial deposits in ................ 87 trend of................................ 86-87 Miocene rocks, occurrence and character of ......... 16-19 Moses Creek, topography at head of ............. 51-52 Mount. (Sce next word of entry.)

Mount Stuart quadrangle, area, location, and features

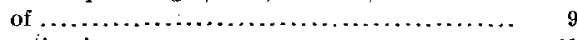

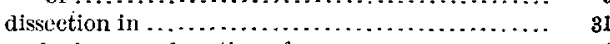
geologic map of portion of ................. 14 geologic structure in..................... 19-20

Naches River, character and history of............. 33 Ellensburg formation along .................. 18

Naches Valley, lava streams along ................. 18

Na varre Coulee, features of.................. $56,57,61$ history of $\ldots . \ldots \ldots \ldots \ldots \ldots \ldots \ldots \ldots \ldots \ldots \ldots \ldots \ldots \ldots, \quad 57$ view of, plate showing $\ldots \ldots \ldots \ldots \ldots \ldots \ldots \ldots \ldots, \quad 56$ Navarre Creek, diversion of, by deformation........ 61

Navarre Peaks, age of ...................... $73-74$

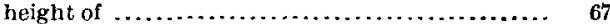
relations and origin of $\ldots \ldots \ldots \ldots \ldots \ldots \ldots \ldots \ldots, .67$ view of, plate showing ........................ Navarre stream, tributaries of ................... 61 Oval Peak, height of ......................... 75

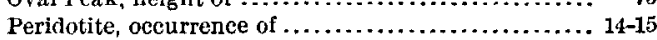
. 
Page.

Peshastin formation, age and character of

Pleistocene deposits, oceurrence and character of .... 19

Pleistocene lavas, occurrence of..................... 18

Powell, J. W., references to ...................... 34, 35

Prince Creek, topography of area near.............. 83

Red Slide, Chelan Butte, topography near.............

Rhyolitc-porphyry, occurrence of .

Ribbon Blufi, Columbia River, topographic features neur.

Ribbon Mecn, altitude of .

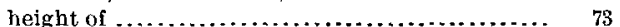

River terraces, occurrence of ...................... 51

Rivers, history of ........................... 32-34

Roslyn formution, coal seam in. occurrence and character of

Russell, I. C., acknowledgments to.

cited on Cascade Mtountains. eited on Columbia River lava ............. 10,11,12,13 cited on Columbia River tributaries ............. 53 cited on geology of central Washington.......... 10 cited on Wenatchee glacier.................... 54 eited on Wenatchee River Canyon............. 53-54 references to $\ldots \ldots \ldots \ldots \ldots \ldots \ldots \ldots \ldots \ldots \ldots .68,71,75,81$

Kussell River, course of .......................... 63

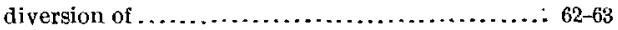
valley of, recognition of ....

valy Harbor Creck, features of canyon above .... 50-60 rocks near head of . .

Sawtooth Range, location of

Gerpentine, Occurrence and cha

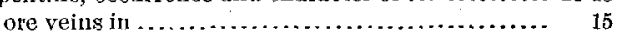

Smith, George Otis, acknowledgements to ........ $\quad 47$ aid rendered by ............................. $48-49$ references to $\ldots \ldots \ldots \ldots \ldots \ldots \ldots \ldots, 64,68-72,79,86,91-92$

Snake River, gorge carved by ..................

Snoqualmie quad rangle, glacial erosion in.......... 36

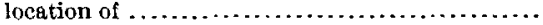

map of

physiography of .

uplift in, axes of ............................. 37

Snoqualmie River, diversion and former course of .... 47

Spurr, J. E., cited on deformation ................ 94,95

Star Peak, height of ............................ 75

Stehekin-Chelan Canyon, character and history of ... 60-61

Stehekin-Chelan River, source and course of ....... 58,63

Stehekin stage, age of $\ldots \ldots \ldots \ldots \ldots \ldots \ldots \ldots \ldots \ldots \ldots . \quad 70$ characteristics of $\ldots \ldots \ldots \ldots \ldots \ldots \ldots \ldots, 69,70$

Stormy Mountain, height of . . . . . . . . . . . . . . 62,89

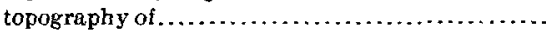

view of, plate showing ........................

Streams of the region, antecedent character of......

Stress in the Cascade Range, direction of ........... 92-95

Structure, geologic, features of .................. 19-21

Strummel Canyon, topography near.

Stuart, Mount, geologic structure of ................ location and height of .

rock forming, character of

Swauk Basin, gold veins in .......................

Swank drainage basin, auriferous gravels in ..........

Swauk formation, gold veins in, occurrence and character of
Sympathetic and unsympathetic relations of topographic features, discussion of................ Taneum Creek Valley, probasalt surface of ........... Tenanway basalt, oceurrence and character of........ 15-16 Tennaway River, lavas on middle fork of . .......... 18-19 Terraces, occurrence of....................... $\quad 51$ Tertiary period, deformation during .............. 91-92 events of ............................... 11-12 Tertiary rocks, reduction of .................... 28 Tieton Basin, lava streams in.................. 18 Tieton Canyon, lavas in ......................... 18 Topographic features, sympathetic and unsympa-

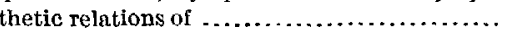

Twenty-five Mile Creek, topography of urea nenr .....

Twisp slope, line of demarcation between Entiat

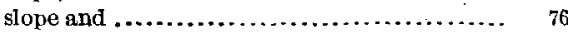

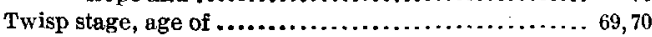
characteristic features of ....................68 $68-69,80$ topographic forms of, development of.......... 80-81 Tyee Mountain, height of $\ldots \ldots \ldots \ldots \ldots \ldots \ldots \ldots \ldots .62,77$ Van Hise, C. R., cited on deformation.............. 94 cited on rock flowage ......................... 94

Volcanic outbursts, lacustral sedimentation suc

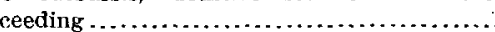

Volcanic rocks, occurrence of Washington, central; map of .................... 10 topographic provinces of $\ldots \ldots \ldots \ldots \ldots \ldots \ldots \ldots \ldots .9$ Waterville downwarp, description of .............. 90 Waterville Platean, location and features of ...... 51-53,72

Wenas basalt, occurrences of .................... 17 Wenas Creek, history of $\ldots \ldots \ldots \ldots \ldots \ldots \ldots \ldots \ldots \ldots . .33-34$ Wenas Valley, geologic and topographic relations of. $\quad 33$ Wenatchee, topographic features ncar ............. $\quad 49$ Wenatchee-Chelan district, Cascade Range, map of .. $\quad 48$

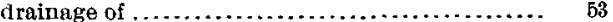
physiographic profiles in, plate showing ......... 78 synthetic discussion of ..................... $68-70$

Wenatehee downwarp and upwarp, description of.... 91 .

Wenatchee Mountains, topography of ............. 22 uplift of ................................ 29-30,91

Wenatchee River, course of ..................... 53

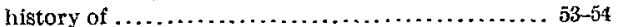

Weuntchee Valley, physiography of .............. 53-55

White Bluffs, Columbia River, Ellensburg formation

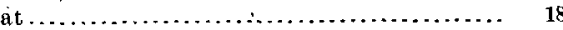

Willis, Bailey, acknowledgements to ............... 10 references to ............................. $28,30,31$

Yakima basalt, age, character, and thickness of ...... 16-17 Yakima basalt and Ellensburg sandstone, contact of, figure showing...

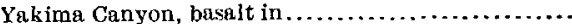
map of, with geologie section .................. view of, at Beaver Bend, plate showing...........

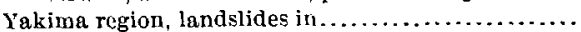

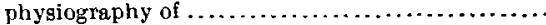

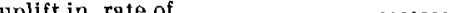

Yakima River, area drained by .................. 9 character of .............................. $38-39$

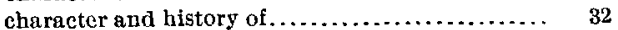
region traversed by, features of ............. 9 tributaries to, position of .................... volcanic rocks along $\ldots \ldots \ldots \ldots \ldots \ldots \ldots \ldots \ldots, \quad 17$

15 Yakima Valley, gravels in ..................... 19 

PUBLICATIONS OF UNITED STATES GEOLOGICAL SURVEY.

[Professional Paper No. 19.]

The serial publications of the United States Geological Survey consist of (1) Annual Reports, (2) Monographs, (3) Professional Papers, (4) Bulletins, (5) Mineral Resources, (6) Water-Supply and Irrigation Papers, (7) Topographic Atlas of the Unitẹd States-folios and separate sheets thereof, (8) Geologic Atlas of the United States-folios thereof. The classes numbered 2, 7, and 8 are sold at cost of publication; the others are distributed free. A circular giving complete lists may be had on application.

The Bulletins, Professional Papers, and Water-Supply Papers treat of a variety of subjects, and the total number issued is large. They have therefore been classified into the following series: $A$, Economic geology; B, Descriptive geology; C, Systematic geology and paleontology; D, Petrography and mineralogy; E, Chemistry and physics; F, Geography; G, Miscellaneous; H, Forestry; I, Irrigation; J, Water storage; K, Pumping water; L, Quality of water; M, General hydrographic investigations; $N$, Water power; $O$, Underground waters; $P$, Hydrographic progress reports. This paper is the sixty-fourth in Series $\mathrm{C}$, the complete list of which follows. ( $\mathrm{B}=$ Bulletin, $\mathrm{PP}=$ Professional Paper.)

\section{SERIES C, SYSTEMATIC GEOLOGY AND PALEONTOLOGY.}

B 3. Fossil faunas of Upper Devonian, along the meridian $76^{\circ} 30^{\prime}$, from Tompkins County, New York, to Bradford County, Pennsylvania, by H. S. Williams. 1884. $36 \mathrm{pp}$.

B 4. Mesozoic fossils, by C. A. White. $1884.36 \mathrm{pp}, 9 \mathrm{pls}$.

B 10. Cambrian faumas of North America; preliminary studies, by C. D. Walcott. 1884.74 pp., 10 pls. (Out of stock.)

B 11. Quaternary and recent Mollusca of the Great Basin, with descriptions of new forms, by R. Ellsworth Call. Introduced by a sketch of the Quaternary lakes of the Great Basin, by G. K. Gilbert. $1884.66 \mathrm{pp}, 6 \mathrm{pls}$.

B 15. Mesozoic and Cenozoic paleontology of California, by C. A. White. 1885. 33 pp.

B 16. Higher Devonian faunas of Ontario County, New York, by J. M. Clarke. 1885. 86 pp., 3 pls.

B 18. Marine Eocene, fresh-water Miocene, and other fossil Mollusca of western North America, by C. A. White. 1885. 26 pp., 3 pls.

B 19. Notes on the stratigraphy of California, by G. F. Becker. 1885. 28 pp. (Out of stock.)

B 22. New Cretaceous fossils from California, by C. A. White. $1885.25 \mathrm{pp}, 5 \mathrm{pls}$.

B 24. List of marine Mollusca, comprising the Quaternary jossils and Recent forms from American localities between Cape Hutteras and Cape Roque, including the Bermudas, by W. H. Dall. 1885.336 pp.

B 29. Fresh-water invertebrates of the North American Jurassic, by C. A. White. 41 pp., 4 pls.

B 30. Second contribution to the studies on the Cambrian faunas of North America, by C. D. Walcott. 1886.369 pp.: 33 pls. (Out of stock.)

B 31. Systematic review of our present knowledge of fossil insects, including myriapods and arachnids, by $\mathrm{S}$. H. Scudder. 1886. $128 \mathrm{pp}$.

B 34. Relation of the Laramie molluscan fauna to that of the succeeding fresh-water Eocene and other groups, by C. A. White. 1886. 54 pp., 5 pls.

B 37. Types of the Laramie flora, by L. F. Ward. $1887.354 \mathrm{pp}, 57 \mathrm{pls}$.

B 41. Fossil faunas of the Upper Devonian-the Genesee section, New York, by H. S. Williams, $1887.121 \mathrm{pp} ., 4 \mathrm{pls.}$

B 43. Tertiary and Cretaceous strata of the Tuscaloosa, Tombigbee, and Alabama rivers, by E. A. Smith and L. C. Johnson. 1887. 189 pp., 21 pls.

B 51. Invertebrate fossils from the Pacific coast, by C. A. White. 1889.102 pp., 14 pls. (Out of stock.)

B 56. Fossil wood and lignite of the-Potomac formation, by F. H. Knowiton. 1889 . $72 \mathrm{pp}$., 7 pls.

B 63. Bibliography of Paleozoic Crustacea from 1698 to 1889, including a list of North American species, and a systematic arrangement of genera, by A. W. Vogdes. $1890 . \quad 177 \mathrm{pp}$.

B 69. Classed and annotated bibliography of fossil insects, by S. H. Scudder. $1890.101 \mathrm{pp}$.

B 71. Index to known fossil insects of the world, including myriapods and arachnids, by S. H. Scudder. 1891.744 pp. 
B 77. The Texan Permian and its Mesozoic types of fossils, by C. A. White. 1891. 51 pp., 4 pls.

B 80. Correlation papers-Devonian and Carboniferous, by H. S. Williams. 1891. 279 pp.

B 81. Correlation papers-Cambrian, by C. D. Walcott. 1891. $447 \mathrm{pp}, 3$ pls. (Out of stock.)

B 82. Correlation papers-Cretaceous, by C. A. White. 1891, 273 pp., 3 pls.

B 83. Correlation papers-Eocene, by W, B. Clark. 1891. 173 pp., 2 pls.

B 84. Corrclation papers-Neocene, by W. H. Dall and G. D. Harris. 1892.349 pp., 3 pls.

B 85. Correlation papers-The Newark system, by I. C. Russell. I892, 344 pp., 13 pls. (Out of stock.)

B 86. Correlation papers-Archean and Algonkian, by C. R. Van Hise. 1892.549 pp., 12 pls. (Out of stock.)

B 87. Synopsis of American fossil Brachiopoda, including bibliography and synonymy, by Charles Schuchert. 1897. $464 \mathrm{pp}$.

B 88. Cretaceous Foraminifera of New Jersey, by R. M. Bagg, jr. 1898.89 pp., 6 pls.

B 93. Some inscets of special interest from Florissant, Colo., and other points in the Tertiaries of Colorado and Utah, by S. H. Seudder. $1892.35 \mathrm{pp} ., 3 \mathrm{pls}$.

B 97. Mesozoic Echinodermata of the United States, by W. B. Clark. 1893. 207 pp., 50 pls.

B 98. Flora of the outlying Carboniferous basins of southwestern Missouri, by David White. $1893.139 \mathrm{pp} ., 5 \mathrm{pls}$.

B 101. Insect fauna of the Rhode Island coal field, by S. H. Scudder. 1893.27 pp., 2 pls.

B 102. Catalogue and bibliography of North American Mesozoic Invertebrata, by C. B. Boyle. 1893.315 pp.

$B$ 105. The Laramie and the overlying Livingston formation in Montana, by W. H. Weed, with report on flora, by F. H. Knowlton. 1893, 68 pp., 6 pls.

B 106. Colorado formation and its invertebrate fauna, by T. W. Stanton. 1893.288 pp., 45 pls. (Out of stock.)

B 110. Paleozoic section in the vicinity of Three Forks, Mont, by A. C. Peale. 1893.56 pp., 6 pls.

B 120. Devonian system of eastern Pennsylvania and New York, by C. S. Prosser. 1895.81 pp., 2 pls.

B 121. Bibliography of North Americun paleontology, by C. R. Keyes. $1894.251 \mathrm{pp}$.

B 124. Revision of North American fossil cockroaches, by S. H. Scudder. 1895.176 pp., 12 pls.

B 128. Bear River formation and its characteristic fauna, by C. A. White. 1895. 108 pp., 11 pls.

B 133. Contributions to the Cretacous paleontology of the Pacific coast: The fauna of the knoxville beds, by $T$. W. Stanton. 1895. $132 \mathrm{pp}, 20 \mathrm{pls.}$

B 134. Cambrian rocks of Pennsylvania, by C. D. Walcott. $1896.43 \mathrm{pp} ., 15$ pls.

B 141. Eocene deposits of the middle Atlantic slope in Delaware, Maryland, and Virginia, by W. B. Clark. 1896.167 pp., 40 pls.

B 142. Brief contribution to the geology and paleontology of northwestern Lonisiana, by T. W. Vaughan. 1896.65 pp., 4 pls.

B 145. Potomac formation in Virginia, by W. M. Fontaine. 1896.149 pp., 2 pls.

B 151. Lower Cretaceous gryphæas of the Texas region, by R. T. Hill and T. W. Vaughan. $1898.139 \mathrm{pp} ., 35 \mathrm{pls}$.

B 152. Catalogie of Cretaceous and Tertiary plants of North America, by F. H. Knowlton. 1898. $247 \mathrm{pp}$.

B 153. Bibliographic index of North American Carboniferons invertebrates, by Stuart Weller. $1898.653 \mathrm{pp}$

B 163. Flora of the Montana formation, by F. H. Knowlton. 1900.118 pp., 19 pls.

B 173. Synopsis of American fossil Bryozoa, including bibliography and synonymy, hy J. M. Nickles and R. S. Bassler. 1900. $663 \mathrm{pp}$.

B 179. Bibliography and catalogue of fossil Vertebrata of North America, by O. P. Hay. $1902.868 \mathrm{pp.}$

B 191. North American geologie formation names: Bibliography, synonymy, and distribution, by F. B. Weeks. 1902. $448 \mathrm{pp}$.

- B 195. Structural details in the Green Mountain region and in eastern New York (second paper), by T. Nelson Dale. 1902. 22 pp., 4 pls.

B 204. Fossil flora of the John Day Basin, Oregon, by F. H. Knowlton. 1902. 153 pp., 17 pls.

B 205. The Mollused of the Buda limestone, by G. B. Shattuck, with an appendix on the corals of the Buda limestone, by T. W. Vaughan. $1903.94 \mathrm{pp} ., 27$ pls.

B 206. A study of the fauna of the Hamilton formation of the Cayuga Lake section in central New York, by $H$. F. Cleland. 1903. 112 pp., 5 pls.

B 210. The correlation of geologicul faunas; a contribution to Devonian paleontology, by H. S. Williams. $1903 . \quad 147 \mathrm{pp} ., 1$ pl.

B 211. Stratigraphy and paleontology of the Upper Carboniferous rocks of the Kansas section, by G. I. Adams, G. H. Girty, and David White. 1903.123 pp., 4 pls.

PP16, Carboniferous formations and faunas of Colorado, by G. H. Girty. $1903.546 \mathrm{pp}, 10 \mathrm{pls}$.

PP19. Contributions to the geology of Washington, by G. O. Smith and Bailey Willis. 1903.101 pp., 20 pls.

Communications should be addressed to

The Director,

United States Geological Survey,

OCTOBE R, 1903.

WASHINGTON, D. C. 


\section{IIBRARY CATALOGUE SLIPS.}

[Mount each slip upon a separate card, placing the subject at the top of the second slip. The name of the series should not be repeated on the series card, but the additional numbers should be added, as received, to the first entry.]

\section{Smith, George Otis.}

... Contributions to the geology of Washington: Geology and physiography of central Washington, by George Otis Smith; Physiography and deformation of the Wenatchee-Chelan district, Cascade Range, by Bailey Willis. Washington, Gov't print. off., I903.

101, III p. 20 pl. (incl. maps), 3 fig. $29 \frac{1}{2} \times 23^{\mathrm{cm}}$. (U. S. Geological survey. Professional paper no. 19.)

"Literature": p. 10-13.

Subject series C, Systematic geology and paleontology, 64.

\section{Smith, George Otis.}

... Contributions to the geology of Washington: Geology and physiography of central Washington, by George Otis Smith; Physiography and deformation of the Wenatchee-Chelan district, Cascade Range, by Bailey Willis. Washington, Gov't print. off., I903.

101, III p. 20 pl. (incl. Inaps), 3 fig. $29 \frac{1}{2} \times 23^{\mathrm{em}}$. (U. S. Geological aurvey. Professional paper no. 19.)

"Literature": p. 10-13.

Subject series C, Systematic geology and paleontology, 64 .

\section{U. S. Geological survey.}

Professional papers.

no: I9. Smith, G. O. Contributions to the geology of Washington ... by G. O. Smith and Bailey Willis. I903.

\section{U. S. Dept. of the Interior.}

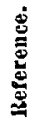
see also

U. S. Geological survey. 
